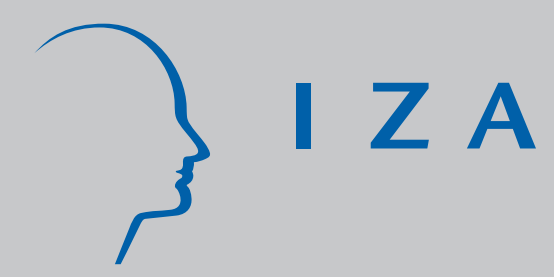

IZA DP No. 253

Living Standards and Economic Vulnerability in Turkey between 1987 and 1994

Ruslan Yemtsov

J anuary 2001 


\title{
Living Standards and Economic Vulnerability in Turkey between 1987 and 1994
}

\author{
Ruslan Yemtsov \\ World Bank, Washington, D.C. and IZA, Bonn \\ Discussion Paper No. 253 \\ January 2001 \\ IZA \\ P.O. Box 7240 \\ D-53072 Bonn \\ Germany \\ Tel.: +49-228-3894-0 \\ Fax: +49-228-3894-210 \\ Email: iza@iza.org
}

This Discussion Paper is issued within the framework of IZA's research area Labor Markets in Transition. Any opinions expressed here are those of the author(s) and not those of the institute. Research disseminated by IZA may include views on policy, but the institute itself takes no institutional policy positions.

The Institute for the Study of Labor (IZA) in Bonn is a local and virtual international research center and a place of communication between science, politics and business. IZA is an independent, nonprofit limited liability company (Gesellschaft mit beschränkter Haftung) supported by the Deutsche Post AG. The center is associated with the University of Bonn and offers a stimulating research environment through its research networks, research support, and visitors and doctoral programs. IZA engages in (i) original and internationally competitive research in all fields of labor economics, (ii) development of policy concepts, and (iii) dissemination of research results and concepts to the interested public. The current research program deals with (1) mobility and flexibility of labor markets, (2) internationalization of labor markets and European integration, (3) the welfare state and labor markets, (4) labor markets in transition, (5) the future of work, (6) project evaluation and (7) general labor economics.

IZA Discussion Papers often represent preliminary work and are circulated to encourage discussion. Citation of such a paper should account for its provisional character. 
IZA Discussion Paper No. 253

January 2001

\title{
ABSTRACT \\ Living Standards and Economic Vulnerability in Turkey between 1987 and 1994
}

Until recently, poverty was a relatively unexplored field of studies in Turkey. This is one of the first attempts outside Turkey to use household survey data from two nationally representative surveys conducted in 1987 and 1994 to get a picture of poverty and its main driving forces. The 1994 data remain until today the latest household level data available for Turkey. The paper finds that Turkey does not face a problem of absolute poverty by the standards of a developing country (in 1994 only 2.5 percent of population lived at less than 1 dollar a day at 1985 purchasing power parity). However, applying a standard that is adequate to Turkey's level of development we find that 7 percent of the population were not able to afford a minimum food basket in 1994 and 36 percent were below the threshold that included alongside minimum food requirements also essential non-food spending. There was a rather small reduction in the poverty risk in Turkey between 1987 and 1994, despite an impressive economic growth, - largely due to negative effects of the macroeconomic crisis of 1996. Poverty in Turkey affects mostly specific groups of the population. Employment and earnings opportunities are key determinants of poverty risks. The profile of poverty by labor market characteristics has remained stable in the 1987-94 period. Macroeconomic and demographic factors (falling fertility and migration from the poorest rural areas to cities) were the main driving forces behind changes in the number of poor.

JEL Classification: I3, J4

Keywords: Inequality, poverty, Gini coefficient, poverty line, minimum consumption basket, cumulative distribution function, unit prices, consumer price index, Engel curve, economies of scale, equivalence scale

\author{
Ruslan Yemtsov \\ World Bank \\ 1818 H Street N.W. Room H4-239 \\ Washington D.C. 20433 \\ USA \\ Tel.: +1-202-458-7276 \\ Fax: +1-202-522-2755 \\ Email: Ryemtsov@worldbank.org
}




\section{LIVING STANDARDS \& ECONOMIC VULNERABILITY IN TURKEY BETWEEN 1987 and 1994}

Turkey does not face a problem of absolute poverty by the standards of a developing country. Poverty in Turkey affects mostly specific groups of the population. Employment and earnings opportunities are key determinants of poverty risks. The profile of poverty by labor market characteristics has remained stable in the 1987-94 period. Macroeconomic and demographic factors were main driving forces behind changes in the number of poor.

\section{Background, data and methodology of the paper}

1. Living standards and poverty analysis in Turkey. Poverty is a relatively unexplored field of studies in Turkey. Partly this was due to availability of detailed household data. However, there is already a tradition of poverty analysis that uses household survey results both to establish the overall incidence of poverty and to inquire what groups of the population are poor (poverty profile). Recent studies by Dansuk (1997), Dumanli (1996), Erdogan (1997), Erdogan (1998), Uygur and Kasnakoglu $(1998)^{1}$ have relied on household survey data (unit records or grouped) to arrive at the picture of relative and absolute deprivation in Turkey. However, with the exception of Erdogan $(1997,1998)$, none of these studies have used data for the whole country from 1994 household survey.

2. The analysis presented in this paper is a result of joint effort by the team from Household Surveys Department of the State Institute of Statistics (SIS) of the Prime Ministry of Turkey and the World bank ${ }^{2}$. Our analysis directly benefited from the studies of R.Dumanli, E.Erdogan, S.Uygur and Z.Kasanokoglu. The team acknowledge the support of SIS management during the whole duration of the analysis and inputs from T.Bulutay, R.Dumanli, S.Uygur and E.Erdogan for conceptualizing approaches to the study of households living standards.

3. Data. The analysis was based on unit record data from two nation-wide household surveys conducted in 1987 and 1994. Household Income and Consumption Expenditure Survey $(\mathrm{HICES})^{3}$ was conducted by the Household Surveys Department of the State Institute of Statistics (SIS) of the Prime Ministry in 1994-95. The HICES is the most recent nationally representative household survey in Turkey. As explained in Technical annex, the quality of data has also much improved in 1994 compared to 1987, and results from two surveys are not directly comparable. Therefore, we have chosen 1994 survey to be the main datasource for the analysis. In addition, the use of 1987 survey strengthens the dynamic nature of the living standards profile and allow for a better analysis of the link between living standards and macroeconomic developments in the country.

\footnotetext{
${ }^{1}$ R.Dumanli (1996) Poverty and its dimensions in Turkey, Ankara, SPO (in Turkish), 1996; G. Erdogan (1997) Poverty definitions and poverty in Turkey. Ankara, SIS; G. Erdogan(1998) Poverty in Turkey: Level and Profile. SIS (in Turkish), Ankara, SIS; S.Uygur and Z.Kasanokoglu (1998) Estimation of poverty line: Turkey 1994. Ankara, SIS.

2 The SIS team was lead by Murat Karaktas and Ozlem Sarica and comprised Sema Alici, Didem..., Hulia ..., Muzzeyn ...; the World Bank team consisted of Ruslan Yemtsov (ECSPE, economist) and Diane Steel (DECRG, database consultant)

3 The 1994 survey collected information on consumption and income of a household during the survey month. In addition, in 1995 same households were visited to collect the information on income for the whole past year. The design and organization of the survey is fully described in SIS publications, such as SIS(1998) Results of the household income distribution survey, 1994; Household consumption expenditures survey results, SIS(1998), and 1994 Household consumption expenditures survey methodology, SIS(1998).
} 
4. Welfare indicator. Typical measures of well-being are income, consumption, ownership of assets or durables and non-monetary indicators of basic social services, such as access to health care and education. The analysis has relied primarily on consumption as the primary measure of living standards, but other indicators were also used.

5. Monthly current consumption (excluding investment and business spending and including consumption from stocks) was used as the primary welfare indicator. There are three reasons why consumption is preferred over income. First, current consumption is often taken to be a better indicator of the standard of living, since the utility level depends primarily on actual consumption of goods and services. Second, current consumption may also be a best possible approximation to long-term average well-being, because consumption tend to fluctuate much less than incomes. Third, experience shows that data on consumption are more accurately collectable. Respondents in agricultural and informal sectors may have difficulties in recalling correctly all kinds of income they receive.

6. Consumption was used as the primary welfare indicator for the analysis of living standards. We tried to measure as accurately as possible total monthly current consumption of a household, including monetary and non-monetary components and imputed rents. In addition to consumption we have used data on ownership of consumer durables. Unfortunately, household surveys in Turkey contain little information about access to health an education, and the use of a more comprehensive indicator of living standards at the household level was not possible.

7. On the other hand, there is a prevailing tradition to use income rather than consumption for the analysis of living standards in Turkey4. In the case of Turkish HICES of 1994 there are relatively small differences between ranking of households by income versus consumption. Thus, one could also use income as welfare indicator especially when using an internationally accepted methodology (for example, method recommended by OECD) that specifically requires the use of income. That would produce overall incidence of poverty that is comparable to statistics from other countries that use the same approach. However, this approach is not a substitute for using consumption for reasons outlined in the Technical annex.

8. Unit of analysis. The analysis in the profile focuses on living standards of Turkish households; if household is deemed to be poor, all its members are counted as poor. The implicit assumption here is that all individual members of a household benefit equally (or in a constant proportion, depending on their age and gender, called equivalence scale), from the household's expenditure or income. These coefficients are based on the minimum caloric needs for different demographic groups, and all members are expressed as "equivalent adults".

9. It is possible, in addition, that there exist economies of scale in consumption, such that the per capita cost of reaching a certain welfare level is lower in large households than in small ones. For example, cost of heating might depend on dwelling characteristics, irrespective of whether the residing family is large or small. But the per capita cost of heating is, of course, lower for the large family. Effective household size is obtained using this economies of scale parameter and number of equivalent adults in a household. For OECD countries the scale parameter equal to 0.5 is often used ${ }^{5}$; statistical test for Turkey (reported in the Technical annex) arrived at an estimate of 0.75 .

\footnotetext{
${ }^{4}$ Most of the poverty studies done so far in Turkey have relied on income criteria.

${ }^{5}$ Which implies that a family of four has to consume only twice as much as a single person living alone to achieve the same welfare level $\left(4^{1 / 2}=2\right)$
} 
10. Definition of poverty lines: absolute versus relative poverty. Certain amount of arbitrariness is unavoidable in defining the poverty line in practice. Given the uncertainties in setting the poverty lines, the danger of focusing on a single line is evident. In addition, focusing on a single number for the poor gives a wrong impression that what matters is how many poor are there. Instead, there are in fact many grades of affluence and poverty, and one has to identify the profile of the poor, that is who are they and why are they poor.

11. In the broadest definition, poverty is the status of a person who falls short of a level of economic welfare deemed to constitute a reasonable minimum, either in some absolute sense or relative to the standards of a specific society. In the absolute sense, the household is considered poor if it consumes less than the cost of minimum food basket for its members.

\section{Box 1: Comparing Poverty in Turkey to other countries}

Any poverty rate depends critically on the poverty line chosen, and on the choice of methodology used to compute it. For this reason, it is often hard to compare poverty rates across different countries: these comparisons can be meaningless if the respective country poverty lines are widely different. International comparisons in poverty rates require that a similar methodology is applied to different countries. One should always take into account three critical issues:

(i) How the poverty line is set.

Absolute poverty lines are based on a basket of goods that provide minimum nutritional intakes. While norms do not differ much between countries, the exact composition of baskets have to take into account differences in cultures and tastes. And relative prices for food can also vary. This makes comparisons of poverty based on countries-specific lines meaningless. To assure comparability of standards between countries the World Bank uses a One-Dollar-A-Day per capita in 1985 prices poverty line, adjusted for purchasing power parity. This is not an arbitrary line; making such a conversion would give us almost exactly the poverty line developed by Planning commission in India. Thus this line is considered typical for a developing country. The alternative for developed countries is to use an absolute line developed in USA that is equal to $\$ 14.40$ per single adult in 1985 prices. While a clear advantage of applying a single, universal standard to all countries is indisputable, its somewhat arbitrary character and problems in accurately measuring this line, limit its value. Purchasing power parity adjustments, for example, are not designed to reflect the cost of basic goods and services, which may distort the comparability of poverty lines across countries.

(ii) How the size of a household and its needs are measured.

According to World Bank methodology one simply counts the number of people in a household. For most developing countries this is regarded as a justified approach. But these per capita measurements are not used at all in OECD countries. OECD methodology takes into account the economies of scale, such that the per capita cost of reaching a certain welfare level is lower in large households than in small ones. For example, cost of heating might depend on dwelling characteristics, irrespective of whether the residing family is large or small. But the per capita cost of heating is, of course, lower for the large family. Taking into account economies of scale has very substantial impact on how many people are counted as poor. The complexity arises from the fact that economies of scale themselves depend on a variety of economic factors and may differ between countries.

(iii) How well consumption or income are measured.

The surveys on which measurement is based differ in coverage, accuracy and quality between countries. Very often poverty is measured based on only one-month of observation. This normally contributes to somewhat "noisy" data. HICES in Turkey is an example of annual survey. As a result, the data are of better quality. But definitions of consumption and income component often vary between countries and make direct comparisons unreliable.

12. Second, we want to define how many people are economically vulnerable in Turkey. Being vulnerable to poverty means being close to the absolute survival minimum. Not all of the economically vulnerable are poor, but they are close enough to the bare minimum, and an economic shock (loss of employment, disability etc.) may mean for them a fall into an absolute deprivation. 
13. The methodologies developed in the World Bank (as described in Ravallion (1994)) was chosen to set the internationally comparable absolute poverty line (One-Dollar-A-Day), the absolute poverty line based on minimum food basket, and the economic vulnerability line. The relative line was set according to one of the variants of methodology developed by OECD ${ }^{6}$. Details of setting poverty lines is depicted in the Technical annex.

14. To assure comparability of standards between countries the World Bank uses a OneDollar-A-Day per capita poverty line, adjusted for purchasing power parity (in 1985 prices). This is not an arbitrary line: making such a conversion would give us almost exactly the poverty line developed by the Planning Commission in India. Thus this line is considered typical for a developing country. For 1994 in Turkey this line amounted to about 450 thousand TL per month.

15. The minimum food basket composed of 19 food items was developed by Turkish academics. The poor in the absolute sense are the households whose current consumption per equivalent adult (with economies of scale adjustment) falls short of the current local cost of the minimum food basket. On average for all survey period the cost of food basket was about TL 1.1 mln. per equivalent adult (36 US dollars at average exchange rate).

16. To the cost of minimum food basket we add allowances for non-food items, as suggested by actual consumption patterns of the less affluent, to arrive at economic vulnerability line. The vulnerability line averaged for all survey period at TL $2.1 \mathrm{mln}$. for a single adult or TL $5.7 \mathrm{mln}$. for an average Turkish household (about 190 US dollars for household per month). In per capita term the line was about 24 percent of GDP per capita in 1994.

17. According to the variant of OECD methodology used to set the relative line, it equals $1 / 2$ (50\%) of the monthly median expenditure per equivalent adult defined according to OECD equivalence scale. Household with monthly income less than the corresponding relative line are called relatively poor, or poor according to OECD definition. On average for all month of the survey the relative poverty line amounted to about TL $4 \mathrm{mln}$. per household (137 US dollars for an average household per month).

\section{Overall incidence of poverty in $\mathbf{1 9 9 4}$ and reliability of poverty measures}

18. Absolute poverty in Turkey is low based on international standard. We find extremely low incidence of poverty that puts Turkey in the range of countries with small incidence of absolute deprivation. Thus Turkey does not face an acute problem of absolute poverty by the standards of a developing economy ${ }^{7}$. But it does not mean that the problem of deprivation and economic vulnerability does not exists in Turkey.

\footnotetext{
${ }^{6}$ Other variants of methodology used are reported in technical annex.

7 Applying a developed country standard shows that Turkey is not yet a high-income economy. USA absolute poverty line (US\$ 14.40 per single adult at PPP) with corresponding equivalence scale to account for family size, shows that 80 percent of the population is poor.
} 
Table 1: International comparisons of absolute poverty in middle- income countries 1990-1995

Percentage of people living at less than one dollar a day at purchasing power parity (in 1985 prices), in percent to population

\begin{tabular}{|l|c|}
\hline Country & Poverty incidence \\
\hline Colombia & 7.4 \\
Poland & 6.8 \\
Malaysia & 5.6 \\
Tunisia & 3.9 \\
Czech Republic & 3.1 \\
Bulgaria & 2.6 \\
Turkey & $\mathbf{2 . 5}$ \\
Jordan & 2.5 \\
Morocco & 1.1 \\
Hungary & 0.7 \\
\hline Source: all countries, except Turkey - World bank, WDI(1998), Turkey - 1994 HIICES, PPP - OECD. \\
\hline
\end{tabular}

19. Absolute poverty based on country-specific minimum food basket is also low. The minimum food allowances adopted in Turkey are relatively high by international standards (as shown in technical annex), but only $5.7 \%$ of households and $7.2 \%$ of the population could be called as poor (total consumption below the cost of the minimum food basket).

20. But unlike absolute poverty, economic vulnerability is a problem. Relatively large allowances are made for non-food spending in the minimum consumption basket. Consequently, absolute poverty line is set at the high level, and substantial number of households (31\%) and population $(36 \%)$ have consumption below this threshold. This absolute poverty, as we have mentioned does not represent a deprivation for most of basic needs and should not be compared to poverty incidence in developing countries. Those who are very poor by the Turkish standards in fact fare not worse or better than the "usual" poor in less developed economies. But substantial number of people close to minimum by the standard adequate to Turkey's level of development is a cause for concern.

21. Precision in estimating the incidence of economic vulnerability. Since there is a considerable concentration of population just around the vulnerability line, and the 95\%confidence interval for headcount is relatively large ( \pm 2 percentage points $)^{8}$. When population is "bunched" around the line, even small changes in the methodology of measuring economic vulnerability produce big changes in the number of people who are deemed vulnerable.

However, characteristics of the economically vulnerable and poor population are robust to changes in the methodology and the size of poverty.

22. Relative poverty. According to relative poverty methodology (accepted in most OECD countries) $14.7 \%$ of the population have total annual incomes below the relative poverty line (and 15.7 percent are poor based on the current monthly income). Comparing the incidence of relative poverty in Turkey with other countries as reported in LIS studies, we find that Turkey has higher prevalence of relative income poverty than any OECD-member European country.

8 The estimate of standard error obtained using Huber/White sandwich procedure that takes into account survey sample clustering effect. Details are reported in the technical annex or could be found in Deaton (1998). 
Table 2: Three methods to measure vulnerability and poverty and results of their application to HICES 1994 in Turkey.

\begin{tabular}{cccccc}
\hline Methods: & $\begin{array}{c}\text { Welfare } \\
\text { aggregate }\end{array}$ & Welfare measure* & Poverty line & $\begin{array}{c}\text { Percent of } \\
\text { households that } \\
\text { are poor }\end{array}$ & $\begin{array}{c}\text { Percent of } \\
\text { population in } \\
\text { poor households }\end{array}$ \\
\hline $\begin{array}{c}\text { Absolute } \\
\text { poverty }\end{array}$ & $\begin{array}{c}\text { Current } \\
\text { consumption }\end{array}$ & $\begin{array}{c}\text { Household } \\
\text { consumption/(E) }\end{array}$ & $\begin{array}{c}\text { Local** cost of }^{0.75} \\
\text { minimum food basket }\end{array}$ & $5.7 \%$ & $7.3 \%$ \\
\hline $\begin{array}{c}\text { Economic } \\
\text { vulnerability to } \\
\text { poverty }\end{array}$ & $\begin{array}{c}\text { Current } \\
\text { consumption }\end{array}$ & $\begin{array}{c}\text { Household } \\
\text { consumption/(E) }\end{array}$ & $\begin{array}{c}\text { Local cost of } \\
\text { minimum food } \\
\text { basket**+non-food } \\
\text { allowance }\end{array}$ & $31.2 \%$ & $36.3 \%$ \\
\hline $\begin{array}{c}\text { Relative } \\
\text { income } \\
\text { poverty }\end{array}$ & Total income & $\begin{array}{c}\text { Household } \\
\text { income/(n) }\end{array}$ & $\begin{array}{c}\text { National: } 1 / 2 \text { of the } \\
\text { median income }\end{array}$ & $14 *$ \\
\hline
\end{tabular}

Notes: $*_{\mathrm{n}}$ is the number of family members, $\mathrm{E}$ is the number of equivalent adults with the caloric scale (FAO)

** Local lines are for 7 regions, urban/rural areas and month of the survey

*** In the current month, per equivalent adult defined with OECD equivalence scale

23. Relative poverty. According to relative poverty methodology (accepted in most OECD countries) $14.7 \%$ of the population have total annual incomes below the relative poverty line (and 15.7 percent are poor based on the current monthly income). Comparing the incidence of relative poverty in Turkey with other countries as reported in LIS studies, we find that Turkey has higher prevalence of relative income poverty than any OECD-member European country.

Table 3: Relative poverty: international comparisons.

\begin{tabular}{llc}
\hline Year & Country & Percent poor \\
\hline 1992 & Belgium & 5.5 \\
1994 & Canada & 10.6 \\
1992 & Denmark & 6.9 \\
1994 & Germany & 11.4 \\
1992 & Israel & 12.5 \\
1995 & Italy & 12.8 \\
1995 & Poland & 11.2 \\
1994 & United Kingdom & 10.6 \\
1994 & United States & 17.9 \\
\hline
\end{tabular}

Source: Luxembourg Income Study/ Center for the Study of Population, Poverty and Public Policy/ INSTEAD database. All poverty lines are drawn at $50 \%$ of the annual median disposable income per equivalent adult.

24. For example, relative poverty around 1994 in UK and Germany were close to 11 percent, in Nordic countries varied between 5 and 8 percent, in Italy was about 13 percent. At this time the highest incidence among developed countries was observed in US, where it reached almost 18 percent in 1994. Relative poverty is sensitive to how unequally incomes are distributed among households in the lowest part of income range. International comparisons suggests that Turkey is a high inequality country, and this is another cause for concern.

\section{Trends in economic vulnerability and poverty between 1987 and 1994}

25. Applying same methodologies of measuring economic vulnerability and poverty to 1987 data gives a benchmark to evaluate economic performance and the impact of economic growth on living standards in Turkey. 
26. An important welfare aspect reflecting changes in living standards are developments in living arrangements, reflecting choices of the population related to household size and composition. Between 1994 and 1987 population has increased by 12.5 percent, but the number of households has expanded more rapidly, by almost 21 percent. The average Turkish household has become smaller, changing from 4.8 to 4.4 by 1994 . These developments are certainly a result of the general improvement in living conditions. Rapid increase in the number of households usually is associated with better access to housing and higher real incomes. The alternative is the life in extended families that pool together resources to capture the economies of scale and insure against from unemployment and low income. Thus choosing an independent living reflect higher welfare. To support this conclusion, we also can refer to a rising ownership of consumer durables. However, during the same period, the average number of employed persons per household has fallen, reflecting general sluggishness of labor market conditions.

27. Macroeconomic indicators suggests that there has been a rather unstable progress in rising living standards of the population over time. The accurate measurement of increase in incomes and consumption, though is extremely difficult task for Turkey because of its high levels of inflation. Thus, in 1994 nominal GDP per capita in Turkey was almost 45 times higher than 1987 level. Adjusting for inflation using the CPI would give us a rise of only about 5 percent in 7 years - less than one percent per year. This rather weak performance is partly explained by a severe crisis in 1994.

28. Comparison of 1987 and 1994 surveys results suggests that there was a reduction of about 2.3 percentage points in the overall incidence of economic vulnerability (from 38.5 to 36.2 percent of the population). However, relatively rapid growth of the population meant that this fall was in fact accompanied by an increase in the number of economically vulnerable by more than one million people. The progress in reducing poverty was more pronounced and actually lead to an absolute reduction in the number of the poor in Turkey. Although the direction of change is unmistakable, it is also important to note that the magnitude of decline in poverty is not dramatic. Leaving poverty for most of the households was not equivalent to definitively climbing out of vulnerability.

29. Big population shifts between urban and rural areas, regions and demographic changes were contributing to reduction in the incidence of poverty for the country as a whole, as the population in relatively richer segments was rising fast. Almost a quarter of overall reduction of poverty was due to these "structural" effects. However, this factor was not powerful enough to make a dramatic change in the picture of poverty. Low or even negative growth of consumption within sub-groups was a main reason behind poverty being so persistent.

30. The decomposition of changes in vulnerability using the methodology proposed by Ravallion and Datt shows that the distribution of consumption has worsened (has become more unequal) and this process was slowing down the fall in poverty. Big population shifts between urban and rural areas and demographic changes were contributing to reduction in the incidence of poverty for the country as a whole, as residual terms shows (as the population in relatively richer urban areas has expanded). The decomposition shows the progress in rural areas both in terms of increasing real consumption and in reducing inequality. Urban areas have exhibited both the deterioration in consumption and the negative effect of increasing inequality, with the latter operating as a major factor. 
Table 4: Decomposition of the change in economic vulnerability between 1987 and 1994 (change in percentage points in the vulnerability headcount)

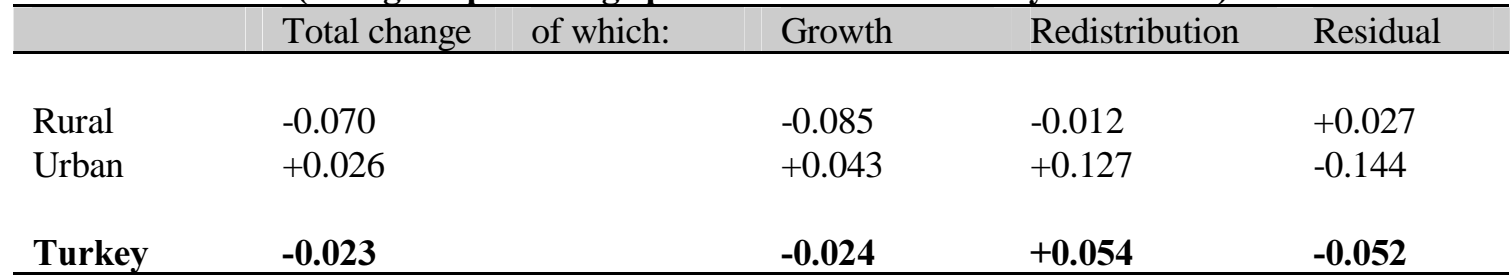

31. When we go a step further and decompose the growth components into "real growth" and "effect of poverty line" (related to prices of poverty basket rising faster or slower than other prices), we find that most of the negative growth effect in urban areas is explained by a fast rise in the cost of poverty basket (probably a 1994 devaluation effect).

\section{Macroeconomic factors of vulnerability}

32. Is economic vulnerability related to macroeconomic factors? It appears that the link between economic stability and poverty reduction is very strong in Turkey. The HICES was conducted in a year when Turkey had suffered from a severe crisis and a sharp devaluation of the lira. By looking at the incidence of poverty by months within 1994 we can observe how the macroeconomic turmoil has impacted on the living standards of the poorest segments of Turkish society. And as chart below suggests the impact has been indeed deep and negative.

33. The surge in the poverty rate that occurred at the time of devaluation and escalating inflation is a good illustration on how the macroeconomic policies impact on the poor. The impact of the economic crises was not short-lived. The poverty rate remained at the extremely high level for 5 consecutive months. Therefore, part of the explanation of why we find such a small change in the proportion of the population that remained vulnerable is the fact that in 1994 a substantial number of normally non-poor fell into vulnerability.

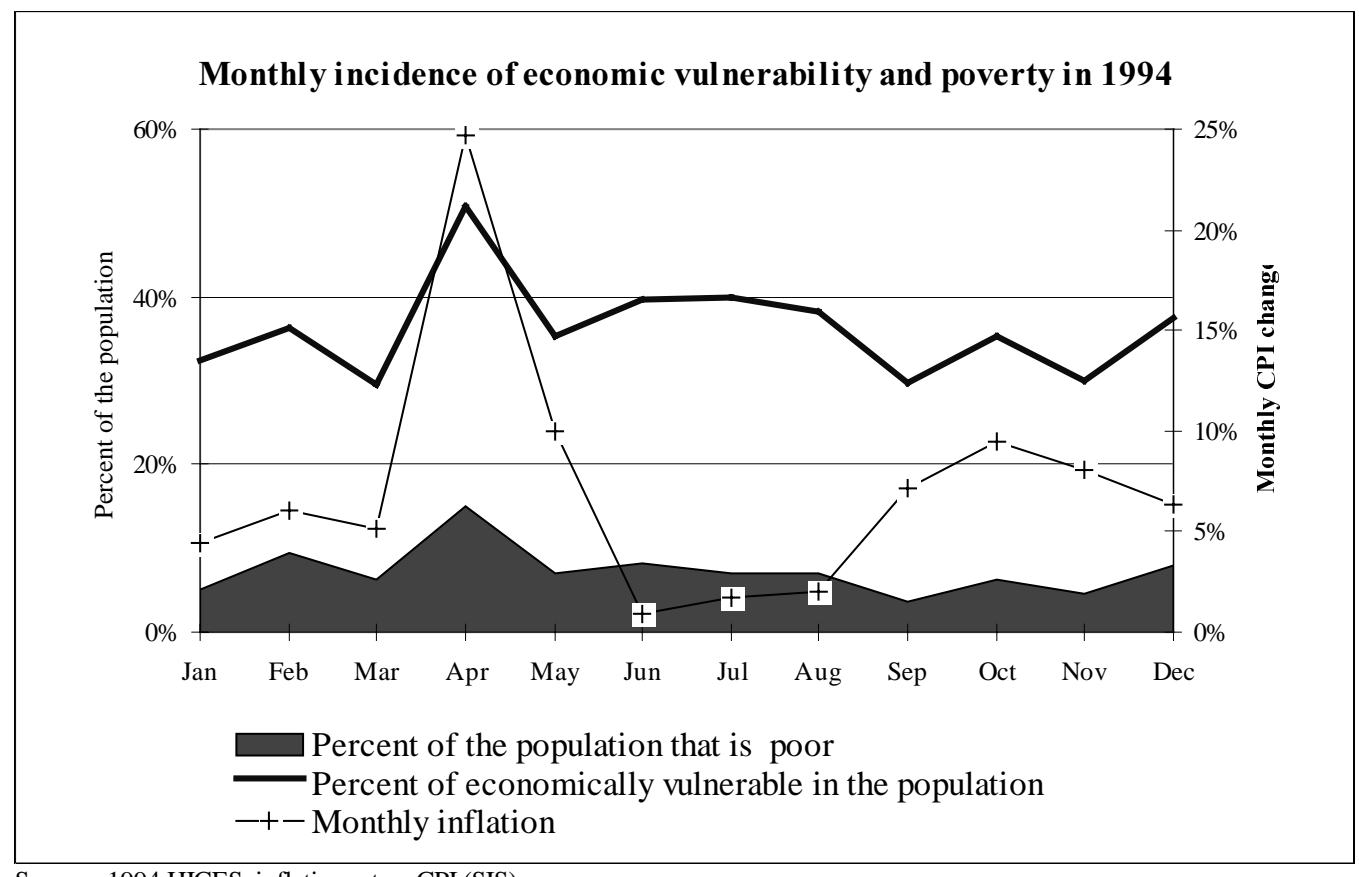

Source: 1994 HICES, inflation rate - CPI (SIS). 
34. What is the potential of growth in reducing poverty? Sustained economic growth the primary factor of rising consumption and thus pulling people out of poverty and vulnerability. Large macrocosmic imbalances can hamper the positive impact of growth, as we have seen on the case of 1994. Large and persistent (if not rising) inequalities in Turkey suggest that the potential of growth alone in reducing the number of poor is further limited. By increasing consumption of all population in 1994 by 1 percent, we would obtain a reduction in the number of vulnerable to poverty by 1.65 percent and of the poor - by 2.16 percent. Thus, it will take 6 years of steady per capita consumption growth of 5 percent per year to reduce vulnerability to half of its current incidence in the population. However, worsening inequality to the level observed for income (Gini of 0.46 ) will completely undone the progress in reducing poverty with economic growth. Thus poverty is stubborn, and growth alone can do only little to reduce poverty if there is no action to more progressive redistribution via taxes and targeted social transfers to increase the living standards of economically vulnerable and poor households.

\section{Profile of living standards}

35. Given a variety of reasons, the poverty or economic vulnerability numbers are always estimated with some degree of arbitrariness. Robustness checks on how accurately the total number of economically vulnerable and poor persons is measured will be reported in the Technical annex. It shows that while overall incidence changes dramatically between approaches, most of the economic characteristics of the poor are very robust to changes in the measurement assumptions. Now we are going to list the most important factors of economic vulnerability and poverty.

\section{Regional determinants}

36. The data on incidence, depth, severity and composition of poverty by regions and by urban versus rural areas, obtained using the basic absolute poverty approach, are presented in Table 3 in the table annex. Changes in poverty incidence by regions between 1987 and 1994 are presented in Table $3 \mathrm{a}$ in the annex. Table 4 in the annex gives the poverty risks by types of urban settlements. Chart 1 below shows the distribution of population, poor and very poor by regions. Chart 2 illustrates the difference between urban and rural living standards and poverty.

37. There are big differences in poverty incidence between regions of the country. Aegean sea region has the poverty risk that is only half of the national average, East and South East Anatolia have the risk that is 50\% above the national average. The distribution of poor and very poor population by regions is different from distribution of all population. But even in richest regions we find groups that are poor. If we try to predict whether the household is poor or not solely based on location, that is running a probit regression of binary outcome variable (whether the household is poor or not) on a set of regional and location (urban/rural) dummies, we find that only $2 \%$ of cases are predicted correctly. Therefore, location by itself is not a cause of poverty. 
Chart 1: Distribution of population and poor population by regions of Turkey in 1994.

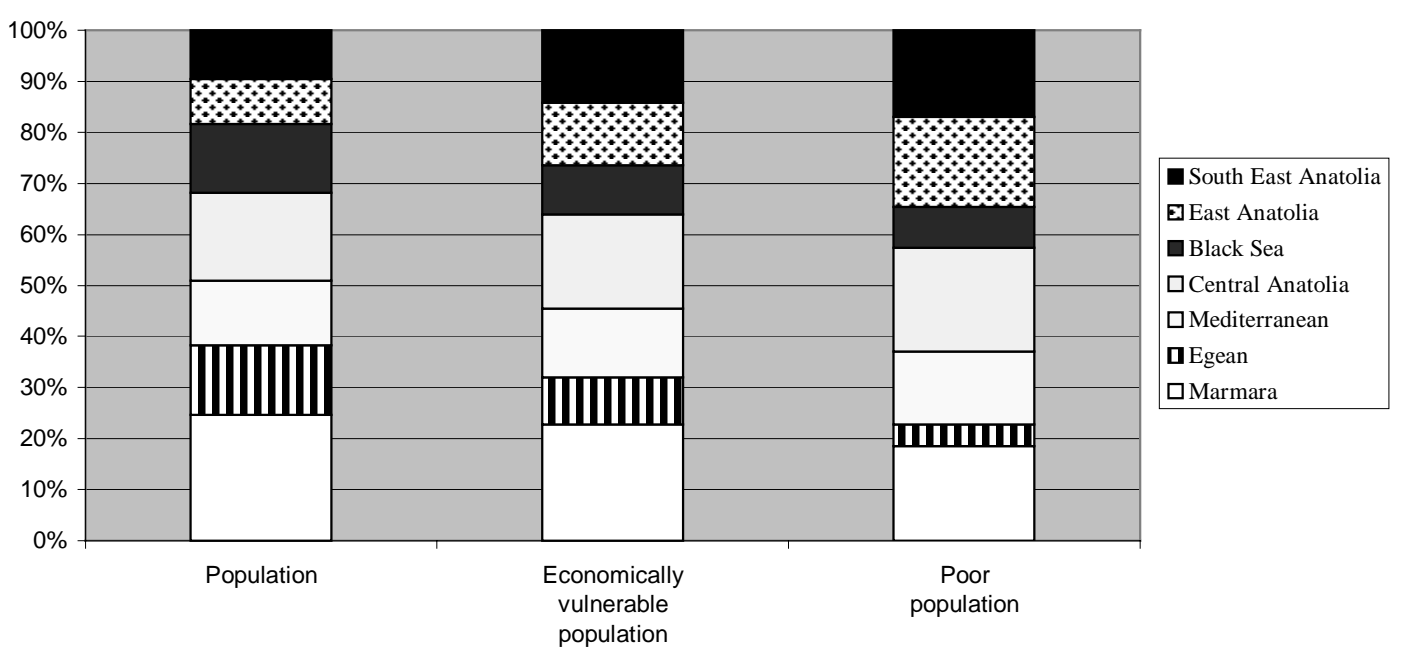

38. Migration flows have tended to reduce poverty in 1987-94, as poorest regions (East Anatolia) have experienced a net decrease in the population, and richest regions - very fast increase in population. As this population pressure was coupled with a brunt of the crisis felt mostly by urban areas, one of the richest regions (Marmara) has experienced faster increase in the number of people below the economic vulnerability line than above the line. Only two regions have managed to reduce simultaneously the number of poor and economically vulnerable while experiencing an increase in the population: Black sea region and Aegean (see Table 3a in the annex); another growing region - South East Anatolia - has experienced a slight decrease in the number of poor, but increase in the number of economically vulnerable. These developments had a weak equalizing effect on regional poverty rates, as poverty rates in poorest regions were falling, and in richest - rising, but poorest regions have remained persistently much poorer than the rest of the country.

39. As Table 3 in the annex witness, there are only small differences in vulnerability and poverty between urban and rural areas. This result is due to applying different poverty lines in urban and rural areas, taking into account lower price level in rural areas. Chart 2 illustrates this point. It shows two curves, for urban and rural areas, representing percentage of the population with consumption below a certain amount. The urban curve lies above the rural, which means that urban population has higher consumption than rural. Figure also has two straight lines corresponding to poverty thresholds: the upper line is urban vulnerability line, and the lower line - rural. The intersection of urban line with curve of consumption distribution for urban areas gives an incidence of economic vulnerability on the horizontal axis (percentage of urban population with consumption below the line). It is evident from the figure, that if we were to apply a single national line, rural economic vulnerability would always be higher than urban. 
Chart 2. Consumption distribution and vulnerability lines

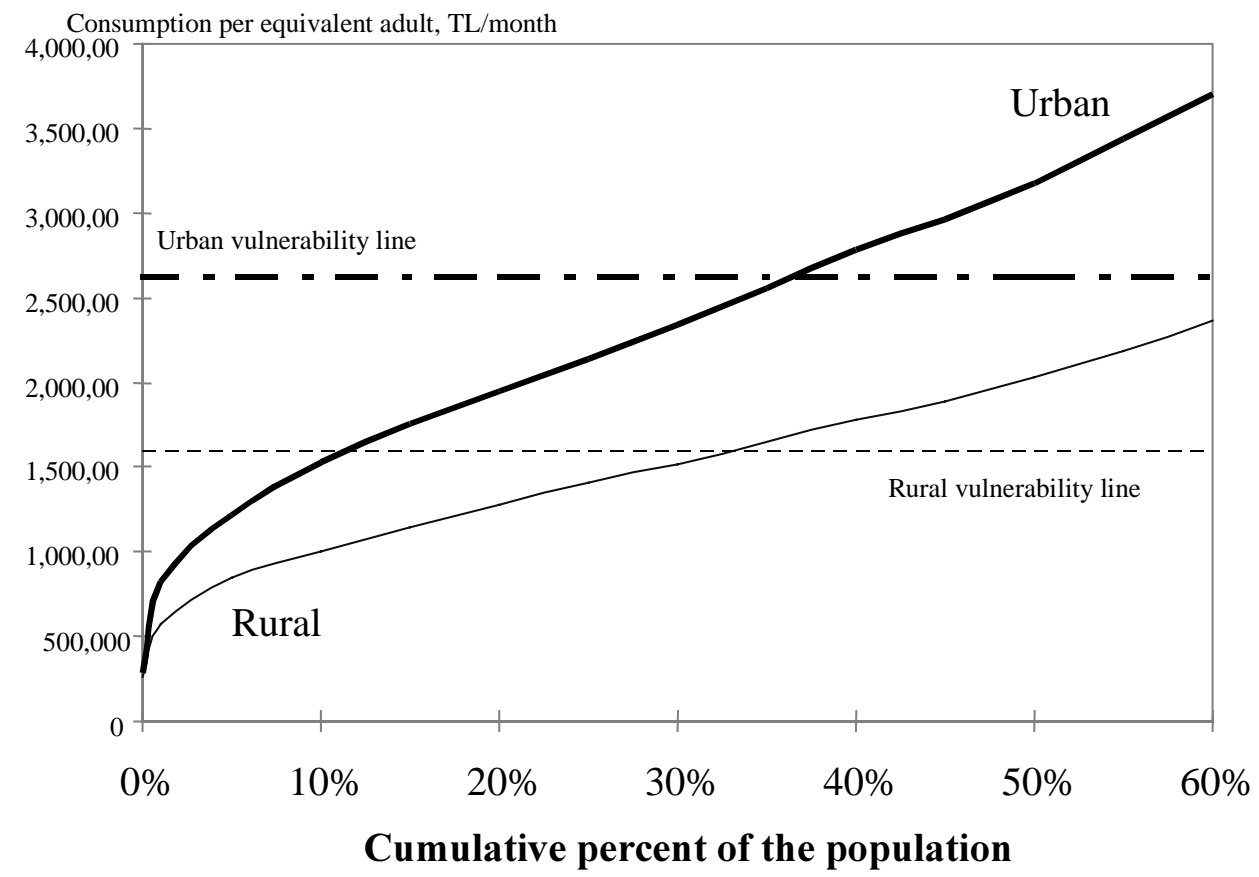

Note: all values are deflated to average 1994 prices using regional CPI indices.

40. Table 4 in the annex witness that in urban areas undeveloped streets and slums have much higher risk of poverty than developed areas. Almost $70 \%$ of the urban poor live in slums and undeveloped areas. Therefore urban areas as a whole may seem to be more prone to poverty than rural areas in part because of the existence and importance of slums and undeveloped streets. High risk of poverty in these areas push the average poverty risk for all urban areas up above the poverty risks of rural areas.

\section{Gender and poverty}

41. Table 5 below gives a comparison of poverty risks for households headed by male versus households headed by female. There is only a slight difference in poverty risks between the households headed by males and females. Poverty of female headed households is, however, deeper. Individual poverty risks on average are the same for men and women.

Table 5: Gender of household head and risk of poverty.

\begin{tabular}{|l|cc|ccc|}
\hline \multicolumn{1}{|c|}{$\begin{array}{c}\text { Gender of household } \\
\text { head }\end{array}$} & $\begin{array}{c}\text { Incidence of } \\
\text { vulnerability }\end{array}$ & $\begin{array}{c}\text { Incidence of } \\
\text { poverty }\end{array}$ & $\begin{array}{c}\text { Average shortfall } \\
\text { of the vulnerable }\end{array}$ & Depth & Severity \\
\hline Female & $37 \%$ & $9 \%$ & $34 \%$ & 0.125 & 0.059 \\
Male & $36 \%$ & $7 \%$ & $30 \%$ & 0.108 & 0.045 \\
\hline
\end{tabular}

42. Two caveats should be attached to these results. First, as shown in technical annex, measured poverty incidence by gender is sensitive to measurement assumptions. Other indicators of well-being witness the unprivileged position of women. HICES (1994) indicates that about $80 \%$ of prime working age males and only $16 \%$ of females in rural Turkey participate 
in some monetarily gainful economic activity ${ }^{9}$. Even in the developed regions employment opportunities available to females are mainly in casual employment.

43. Second, at a minimum, caution should be exercised whenever individual poverty is measured based on household survey data. In reality, household consumption may be distributed very unequally between members, depending on their age, gender or education. Data on the actual differences in living standards within a given household are rarely available. However, we do find significant differences in the educational status of men and women: in 1994 over 30 percent of adult females were still illiterate (as opposed to 9 percent for males). Thus, household-based measures may underestimate the true extent of poverty among females (as shown in Haddad and Kanbur (1990)).

\section{Education and poverty}

44. Table 6 in this section, and Tables 7 in the annex gives details on individual poverty risks of persons with different levels of education, while Tables 8 and 9 in the annex focus on the educational status of children. The dynamic decomposition of changes in poverty and vulnerability risks by levels of education is presented in Table 10 in this section.

45. Education is the characteristic that has the strongest correlation to poverty risk. The education of household head plays a key role in determining whether the household is poor. There is a 10 times difference in poverty risk between the household headed by an illiterate person and a household with the head having the higher education. Same magnitude of differences is observed for individuals, as Table 7 in the annex suggests.

46. There are important differences in educational achievements of children by regions of the country, as shown in Table 8 in the annex. Poorest regions have close to 10 percent of all children in age groups 12-15 who are illiterate. Those who are deprived of even basic education in childhood tend to have poor prospects on a labor market later. Therefore, gaps in education explain some part of regional differences in poverty risks. Remaining problems in access of children to education, as they were spotted by the 1994 survey, particularly in some regions, pose problem for progress in poverty alleviation in the future.

47. There is also a very clear link between the poverty of family and poor educational achievements of children, as Table 9 in the annex suggests. Most of the adolescents who leave school before or just after completing the primary level and seek employment are from poor families. About 5\% of all children in the country between ages 12 and 15 did not completed even primary education and are no longer in school; $70 \%$ of these children are from rural areas; $70 \%$ live in poor households.

\footnotetext{
9 Prime working age is defined between 25 and 40 years. Urban areas do not fare far better than rural: female participation in prime age is only $20 \%$. L..Schwartz (1999) finds that the progress in rising women's education between 1994 and 1998 has been very slow.
} 
Table 6: Poverty profile by the level of education of household head, 1994

\begin{tabular}{|c|c|c|c|c|c|c|c|c|}
\hline & \multicolumn{5}{|c|}{ Poverty indicators } & \multicolumn{3}{|c|}{ Structure, percent } \\
\hline $\begin{array}{c}\text { Education of } \\
\text { household head }\end{array}$ & $\begin{array}{l}\text { Incidence of } \\
\text { vulnerability }\end{array}$ & $\begin{array}{c}\text { Incidence of } \\
\text { poverty }\end{array}$ & $\begin{array}{l}\text { Average } \\
\text { shortfall }\end{array}$ & Depth & Severity & Population & \begin{tabular}{|l} 
Vulnerable \\
population
\end{tabular} & $\begin{array}{c}\text { Poor } \\
\text { population }\end{array}$ \\
\hline illiterate & $52 \%$ & $15 \%$ & $33 \%$ & 0.173 & 0.077 & $13.6 \%$ & $19.7 \%$ & $27.8 \%$ \\
\hline literate w/o diploma & $45 \%$ & $10 \%$ & $31 \%$ & 0.138 & 0.058 & $7.4 \%$ & $9.3 \%$ & $10.7 \%$ \\
\hline primary & $38 \%$ & $7 \%$ & $30 \%$ & 0.115 & 0.048 & $55.8 \%$ & $58.8 \%$ & $55.0 \%$ \\
\hline secondary & $23 \%$ & $2 \%$ & $26 \%$ & 0.060 & 0.023 & $17.9 \%$ & $11.4 \%$ & $6.2 \%$ \\
\hline higher & $5 \%$ & $0 \%$ & $16 \%$ & 0.009 & 0.003 & $5.3 \%$ & $0.8 \%$ & $0.2 \%$ \\
\hline Total & $36.3 \%$ & $7.3 \%$ & $30 \%$ & 0.109 & 0.046 & $100.0 \%$ & $100.0 \%$ & $100.0 \%$ \\
\hline
\end{tabular}

Table 10: Decomposition of economic vulnerability change by education

\begin{tabular}{|c|c|c|c|c|c|c|}
\hline \multirow[b]{2}{*}{$\begin{array}{l}\text { Education of household } \\
\text { head }\end{array}$} & \multicolumn{2}{|c|}{ Vulnerability risks } & \multirow[b]{2}{*}{$\begin{array}{l}\text { Contribution to } \\
\text { poverty change } \\
\text { in the country, } \\
\text { points }\end{array}$} & \multicolumn{3}{|c|}{ of which } \\
\hline & $\begin{array}{c}\text { Incidence of } \\
\text { vulnerability in } \\
1987\end{array}$ & $\begin{array}{c}\text { Incidence of } \\
\text { vulnerability in } \\
1994\end{array}$ & & $\begin{array}{l}\text { due to } \\
\text { change in } \\
\text { risk }\end{array}$ & $\begin{array}{l}\text { due to } \\
\text { population } \\
\text { shifts }\end{array}$ & $\begin{array}{l}\text { interacti } \\
\text { on term }\end{array}$ \\
\hline illiterate & $56 \%$ & $52 \%$ & $-0.9 \%$ & $-0.4 \%$ & $-0.5 \%$ & $+0.0 \%$ \\
\hline literate w/o diploma & $46 \%$ & $45 \%$ & $-1.1 \%$ & $-0.1 \%$ & $-1.1 \%$ & $+0.0 \%$ \\
\hline primary & $40 \%$ & $38 \%$ & $-0.5 \%$ & $-0.8 \%$ & $+0.3 \%$ & $-0.0 \%$ \\
\hline secondary & $25 \%$ & $23 \%$ & $+0.5 \%$ & $-0.3 \%$ & $+0.8 \%$ & $-0.1 \%$ \\
\hline higher & $7 \%$ & $5 \%$ & $-0.1 \%$ & $-0.1 \%$ & $-0.0 \%$ & $+0.0 \%$ \\
\hline Total & $39 \%$ & $36 \%$ & $-2.3 \%$ & $-1.6 \%$ & $-0.6 \%$ & $-0.0 \%$ \\
\hline
\end{tabular}

48. Table 10 presents changes in economic vulnerability between 1987 and 1994 . It shows that over time we find a remarkable stability in relative risks of vulnerability by the level of education. To understand changes in the incidence of vulnerability we decompose the total change (of 2.3 percentage points) into the contributions of each group. We see that most of the positive action has come from lower levels of education. We decompose further each group contribution to the nation-wide change in vulnerability into three components: poverty risk change, structural effect and interaction term. To derive the first element, we apply changes in the risk of poverty to the initial (1987) population structure ( this component is called "poverty risk change). Second term is obtained by applying initial poverty incidence to the changes in the population structure between 1987 and 1994. To obtain the last term we allow simultaneous change in poverty risk and population structure (interaction term).

49. The decomposition shows that changes in the vulnerability risks for the population in the country as a whole were due to the growing education attainment of the population and fall in poverty risks. As a whole, group risks changes have contributed as a whole almost 70 percent of the total change. But when we look more closely at the decomposition for each group, we find that structural effects dominate. Just the rise of literacy rates among the household heads, however small it was (the share of the population has changed by one percentage point), contributed close to 50 percent of the reduction of economic vulnerability and poverty in a nation. This is a clear prove that education does offer the most reliable way out of poverty. 


\section{Labor market status}

50. Occupational characteristics (employment, unemployment or non-participation and type of job contract) are close correlates of poverty risks in Turkey, as revealed by Table 11 below and Tables 13, 14 and 15 in the annex. The Table 12 in the annex depicts changes in poverty risks by the labor market status of persons between 1987 and 1994.

51. A rather surprising factor revealed by the Table 11 below with data on household heads, is that there are only minor differences in poverty risk exists between all employed and all not employed on average (the same conclusion arises from inspection of Table 11 in the annex with data on individuals).

Table 11: Poverty profile by employment status of household head

\begin{tabular}{|c|c|c|c|c|c|c|c|c|}
\hline & \multicolumn{5}{|c|}{ Poverty indicators } & \multicolumn{3}{|c|}{ Structure, percent } \\
\hline $\begin{array}{c}\text { Employment status of } \\
\text { household head }\end{array}$ & $\begin{array}{c}\text { Percent } \\
\text { vulnerable }\end{array}$ & $\begin{array}{l}\text { Percent } \\
\text { poor }\end{array}$ & $\begin{array}{l}\text { Average } \\
\text { shortfall }\end{array}$ & Depth & Severity & Population & $\begin{array}{l}\text { Vulnerable } \\
\text { population }\end{array}$ & $\begin{array}{c}\text { Poor } \\
\text { population }\end{array}$ \\
\hline EMPLOYED & $37 \%$ & $7 \%$ & $30 \%$ & 0.112 & 0.046 & $86.3 \%$ & $88.3 \%$ & $88.3 \%$ \\
\hline regular employee & $31 \%$ & $4 \%$ & $28 \%$ & 0.086 & 0.033 & $29.8 \%$ & $25.4 \%$ & $15.3 \%$ \\
\hline casual and seasonal worker & $58 \%$ & $15 \%$ & $34 \%$ & 0.201 & 0.092 & $9.2 \%$ & $14.8 \%$ & $18.8 \%$ \\
\hline Employer & $17 \%$ & $1 \%$ & $25 \%$ & 0.042 & 0.015 & $6.4 \%$ & $3.0 \%$ & $1.1 \%$ \\
\hline self-employed & $40 \%$ & $9 \%$ & $30 \%$ & 0.121 & 0.051 & $40.9 \%$ & $45.1 \%$ & $53.2 \%$ \\
\hline unpaid family worker & $8 \%$ & $0 \%$ & $23 \%$ & 0.019 & 0.004 & $0.0 \%$ & $0.0 \%$ & $0.0 \%$ \\
\hline NOT EMPLOYED & $31 \%$ & $6 \%$ & $31 \%$ & 0.095 & 0.042 & $13.7 \%$ & $11.7 \%$ & $11.7 \%$ \\
\hline Unemployed & $52 \%$ & $17 \%$ & $37 \%$ & 0.193 & 0.096 & $1.3 \%$ & $1.8 \%$ & $2.9 \%$ \\
\hline Student & $12 \%$ & $0 \%$ & $21 \%$ & 0.026 & 0.007 & $0.1 \%$ & $0.0 \%$ & $0.0 \%$ \\
\hline Housewife & $39 \%$ & $11 \%$ & $36 \%$ & 0.140 & 0.069 & $1.8 \%$ & $2.0 \%$ & $2.7 \%$ \\
\hline Disabled & $49 \%$ & $14 \%$ & $39 \%$ & 0.192 & 0.096 & $0.2 \%$ & $0.2 \%$ & $0.3 \%$ \\
\hline Ill & $39 \%$ & $8 \%$ & $27 \%$ & 0.106 & 0.048 & $0.4 \%$ & $0.4 \%$ & $0.4 \%$ \\
\hline Retired & $23 \%$ & $2 \%$ & $25 \%$ & 0.056 & 0.020 & $7.9 \%$ & $5.0 \%$ & $1.8 \%$ \\
\hline Rentier & $30 \%$ & $3 \%$ & $26 \%$ & 0.080 & 0.030 & $0.6 \%$ & $0.5 \%$ & $0.3 \%$ \\
\hline Elderly & $44 \%$ & $15 \%$ & $34 \%$ & 0.150 & 0.067 & $1.2 \%$ & $1.5 \%$ & $2.6 \%$ \\
\hline Other & $47 \%$ & $22 \%$ & $46 \%$ & 0.218 & 0.130 & $0.2 \%$ & $0.3 \%$ & $0.7 \%$ \\
\hline TOTAL & $36 \%$ & $7 \%$ & $30 \%$ & 0.109 & 0.046 & $100.0 \%$ & $100.0 \%$ & $100.0 \%$ \\
\hline
\end{tabular}

52. Most of the non-population as well as poor population in Turkey live in households where heads are gainfully employed. But within each big group of employed and not employed there are big differences between different types of employment and reasons for non-employment. When individual (household head) is employed in seasonal, casual positions its (household) poverty risk is much higher than for other types of employment and non-employment alike. To put it simply, these are the poorest people in Turkey, poorer than even unemployed. Selfemployment ranks second in terms of poverty risks for all the employed, and 45 percent of all poor in Turkey live in families where a head is self-employed.

53. When individual or household head is unemployed, or disabled, the poverty risks (individual and household) are extremely high and exceed all other not employed groups risks. The largest group with lowest poverty risks amongst the non-employed are pension recipients. 
54. As Table 11 tends to suggest regular employees have poverty risks that are just about the average. This points out to the importance of other factors, that determine the level of earnings, such as education, occupation and type of work contract. The lowest risk is associated with the employment as regular employee covered by the social security, as shown in Table 15. Regular employees not covered by any social insurance are a at a risk of poverty that is twice the risk of insured employees. Employment in State sector is related to much lower (in fact two times lower) risk of poverty than private sector employment, as Table 14 in the annex points out.

55. Table 12 in the annex shows group-specific poverty risks have remained remarkably stable between 1987 and 1994. But as almost al groups have experienced falling or stable poverty risks, these small changes were reinforcing each other. On the other hand, extremely large effects of population shifts were working in the opposite directions. As a result, as in case of education, we find a predominance of within-group effects with substantial shifts in the structure of population. The number of wage employees alone has increased by almost $1.5 \mathrm{mln}$., and the number of unpaid family workers reduced by $0.5 \mathrm{mln}$. However, the positive effect of changing employment structure was almost entirely offset on a national level by an increase in the number of unemployed, a group with the highest incidence of poverty, revealing that the labor market did not serve the Turkish poor well in this period. In large part this was due to the impact of economic crisis of 1994, and witness a presence of a strong link between macroeconomic performance and poverty.

\section{Sector of employment and occupation}

56. Tables 18 below and Annex Tables 16 and 19 (that is a full versions of Table 18), all show the risk of poverty by household's head sector of employment. Table 17 in the annex explores the poverty profile of individuals by their sector of employment and type of contract. Table 20 in the annex is a cross-tabulation of individual employment versus household head employment. Tables 21 and 22 report changes in poverty risks by employment between 1987 and 1994. Table 21 in the annex gives a picture of changes in sectoral poverty risks for household heads. Finally, Table 22 reports changes in the poverty risks by main occupation groups.

57. There are substantial differences in poverty risks between the sector of employment of household heads. Table 18 combines sector of employment and the dominant type of employment in each sector to show both across-sectors and within-sector differences in poverty risks for household. Highest risks are associated with the work in agriculture and construction. The lowest risks are characteristics of employed in power industry and finance and banking sector. Table 18 shows that some of the sector of employment poverty risks can be explained by specific type of job risks that is predominant in each sector. For example, high poverty risks associated with the employment in construction is due to predominance of casual workers in this sector who tend to have highest poverty risk regardless of sector of employment.

58. In terms of poverty decomposition (Table 19 in the annex), most of the poor population as well as most of the overall poverty depth is coming from the households headed by selfemployed in agriculture. It is followed by the casual employment in construction, regular employment in manufacturing and self-employment in trade. Together these four groups account for 55 percent of the vulnerable to poverty, 56 percent of the poverty gap for the country as a whole and 63 percent of the poor population in Turkey. The conclusions of the predominance in total poverty of very specific sectoral and type of employment groups is supported by Table 17 with the poverty risk of only the employed. 
Table 18: Poverty profile: household heads' dominant status of employment for each sector

\begin{tabular}{|l|cc|cc|}
\hline $\begin{array}{c}\text { Sector and dominant status of } \\
\text { employment of household head }\end{array}$ & $\begin{array}{c}\text { Incidence of } \\
\text { vulnerability }\end{array}$ & $\begin{array}{c}\text { Incidence of } \\
\text { poverty }\end{array}$ & $\begin{array}{c}\text { Vulnerable } \\
\text { population }\end{array}$ & $\begin{array}{c}\text { Poor } \\
\text { population }\end{array}$ \\
\hline Agriculture & $\mathbf{4 2 \%}$ & $\mathbf{1 1 \%}$ & $\mathbf{3 3 . 0} \%$ & $\mathbf{4 1 . 8 \%}$ \\
self-employed & $41 \%$ & $10 \%$ & $30.3 \%$ & $38.2 \%$ \\
Mining & $\mathbf{2 8 \%}$ & $\mathbf{3 \%}$ & $\mathbf{0 . 7 \%}$ & $\mathbf{0 . 3 \%}$ \\
Regular employee & $22 \%$ & $1 \%$ & $0.4 \%$ & $0.1 \%$ \\
Manufacturing & $\mathbf{3 6 \%}$ & $\mathbf{5 \%}$ & $\mathbf{1 1 . 9 \%}$ & $\mathbf{8 . 2 \%}$ \\
Regular employee & $37 \%$ & $5 \%$ & $8.0 \%$ & $5.6 \%$ \\
Power, water etc. & $\mathbf{1 8 \%}$ & $\mathbf{2 \%}$ & $\mathbf{0 . 2 \%}$ & $\mathbf{0 . 1 \%}$ \\
Regular employee & $19 \%$ & $3 \%$ & $0.2 \%$ & $0.1 \%$ \\
Construction & $\mathbf{5 0 \%}$ & $\mathbf{1 2 \%}$ & $\mathbf{1 0 . 4 \%}$ & $\mathbf{1 2 . 3 \%}$ \\
Casual and seasonal worker & $60 \%$ & $16 \%$ & $8.1 \%$ & $10.9 \%$ \\
Trade & $\mathbf{3 5 \%}$ & $\mathbf{6 \%}$ & $\mathbf{1 5 . 1 \%}$ & $\mathbf{1 3 . 6 \%}$ \\
self-employed & $38 \%$ & $8 \%$ & $8.5 \%$ & $8.4 \%$ \\
Transport & $\mathbf{3 7 \%}$ & $\mathbf{6 \%}$ & $\mathbf{5 . 9 \%}$ & $\mathbf{5 . 0 \%}$ \\
Regular employee & $34 \%$ & $4 \%$ & $2.3 \%$ & $1.4 \%$ \\
Finance \& banking & $\mathbf{1 9 \%}$ & $\mathbf{0 \%}$ & $\mathbf{0 . 3 \%}$ & $\mathbf{0 . 0 \%}$ \\
Regular employee & $19 \%$ & $0 \%$ & $0.3 \%$ & $0.0 \%$ \\
\hline Services & $\mathbf{2 7 \%}$ & $\mathbf{3 \%}$ & $\mathbf{1 0 . 7 \%}$ & $\mathbf{6 . 9 \%}$ \\
Regular employee & $25 \%$ & $2 \%$ & $8.3 \%$ & $3.5 \%$ \\
NOT EMPLOYED & $\mathbf{3 1 \%}$ & $\mathbf{6 \%}$ & $\mathbf{1 1 . 7 \%}$ & $\mathbf{1 1 . 7 \%}$ \\
TOTAL & $\mathbf{3 6 \%}$ & $\mathbf{7 \%}$ & $\mathbf{1 0 0 . 0 \%}$ & $\mathbf{1 0 0 . 0 \%}$ \\
\hline
\end{tabular}

59. Table 21 shows that sectoral structure of poverty risks has remained stable between 1987 and 1994 with all sectors registering a slight decline in the incidence of poverty and vulnerability. The progress has been fastest in services and infrastructure, and slowest in trade and construction. However, the change in the structure, i.e. reallocation of labor between sectors, was a minor phenomenon, accounting for less than 10 percent in the change in poverty between 1987 and 1994. Thus within-sector factors, rather than structural changes, were playing a predominant role in this period. To large extent this is due to contradictory impact of structural changes. While reduction of employment in agriculture that initially had a highest risk of poverty has been working towards reducing poverty, the expansion of employment in construction and trade with relatively high poverty risks has offset this positive impact almost entirely.

60. Table 20 reveals a more subtle causation behind the sectoral poverty risks discovered by the analysis above of household heads' employment. It shows that households headed by the regular employees tend to have a high dependency rate (almost $2 / 3$ of their members are not working) that might partly explain the relatively high risk of poverty for these households. The manufacturing is a predominant sector of regular employment contracts in new industrial centers that attracts migrants from rural areas. Usually these families are characterized by a very low female participation rate, and a large number dependents living on one earners' salary. Thus, the poverty id high for the group of regular employees partly because of this "within" - family ${ }^{10}$ factors.

61. The picture is different for the households headed by the self-employed. here the dependency rate is low, but there is in fact more unpaid family workers than the self-employed. Thus the reason for high poverty risks in this group is relatively low productivity of employment

${ }^{10}$ Put in citation marks since low participation rate of women is not entirely an intra-family phenomenon. 
in their occupation and lack of other earning opportunities except the work on family shop of farm.

62. Finally, the structure and changes of poverty risks by occupation, as shown in Table 22 in the annex, shows that all groups of employed have contributed to a reduction of poverty. The largest share of poverty reduction in the country can be traced to agricultural workers and manual productive workers, - the most numerous groups among the employed. On the other hand, households without employed heads have experienced an increase in poverty risk and expansion in the number, contributing towards poverty increase in the country. This shows the key role of employment in a poverty alleviation strategy. Even in difficult economic circumstances for almost all groups linked to employment there has been a progress in poverty reduction.

\section{Living arrangements of the poor and economically vulnerable}

63. Poor tend to have quite different living conditions that the non-poor, as revealed by Table 23 below and Chart 3. Table 13 in the Annex reveals individual poverty risks by age groups.

64. Large multigenerational households traditionally are home for a majority of the Turkish population. But at the same time these households tend to have highest risks of poverty. This is why most of the poor live in large extended households, as Table 23 shows. Nuclear families with three and more children are also at the high risk of poverty, but their poverty is even more severe and deep. The presence of children in a household does increase the risks of poverty substantially. Table 13 in the annex shows that children under 10 years old have the highest poverty risk among all age groups. Most of the poor children live in large extended families that have many other dependents.

Table 23: Poverty profile by the type of family: change between 1987 and 1994

\begin{tabular}{|l|c|c|c|ccc|}
\hline \multicolumn{1}{|c|}{ Type of family } & \multicolumn{3}{|c|}{ Poverty in 1994 } & \multicolumn{3}{c|}{ Poverty in 1987 } \\
\hline & $\begin{array}{c}\text { Vulnerable, } \\
\text { percent }\end{array}$ & $\begin{array}{c}\text { Headcount } \\
\text { for the poor }\end{array}$ & $\begin{array}{c}\text { Poor } \\
\text { population }\end{array}$ & $\begin{array}{c}\text { Vulnerable, } \\
\text { percent }\end{array}$ & $\begin{array}{c}\text { Headcount } \\
\text { for the poor }\end{array}$ & $\begin{array}{c}\text { Poor } \\
\text { population }\end{array}$ \\
\hline Single elderly & $25 \%$ & $5 \%$ & $0.2 \%$ & $25 \%$ & $9 \%$ & $0.4 \%$ \\
Single work age adult & $9 \%$ & $1 \%$ & $0.1 \%$ & $8 \%$ & $1 \%$ & $0.0 \%$ \\
Single parent & $39 \%$ & $10 \%$ & $1.9 \%$ & $41 \%$ & $13 \%$ & $1.7 \%$ \\
Single adult and elderly & $21 \%$ & $3 \%$ & $0.6 \%$ & $33 \%$ & $14 \%$ & $1.2 \%$ \\
Couple, no children & $17 \%$ & $3 \%$ & $1.6 \%$ & $20 \%$ & $6 \%$ & $2.7 \%$ \\
Couple, 1 child & $24 \%$ & $2 \%$ & $1.7 \%$ & $22 \%$ & $3 \%$ & $1.8 \%$ \\
Couple, 2 children & $31 \%$ & $4 \%$ & $6.1 \%$ & $31 \%$ & $4 \%$ & $4.0 \%$ \\
Couple, 3+ children & $53 \%$ & $14 \%$ & $23.2 \%$ & $53 \%$ & $15 \%$ & $33.1 \%$ \\
Extended, no children & $21 \%$ & $2 \%$ & $5.0 \%$ & $16 \%$ & $3 \%$ & $2.6 \%$ \\
Extended, 1 child & $31 \%$ & $5 \%$ & $9.6 \%$ & $23 \%$ & $4 \%$ & $3.9 \%$ \\
Extended, 2 children & $40 \%$ & $7 \%$ & $12.8 \%$ & $34 \%$ & $6 \%$ & $6.0 \%$ \\
Extended, 3+ children & $52 \%$ & $14 \%$ & $37.3 \%$ & $51 \%$ & $16 \%$ & $42.5 \%$ \\
\hline TOTAL & $\mathbf{3 6 \%}$ & $\mathbf{7 \%}$ & $\mathbf{1 0 0 . 0 \%}$ & $\mathbf{3 9 \%}$ & $\mathbf{1 0 \%}$ & $\mathbf{1 0 0 . 0 \%}$ \\
\hline
\end{tabular}

65. Single parents are also a highly risky category, but they are not important in terms of number of people. Elderly seems to be mostly integrated within large families. Those who live alone can afford doing it and have in fact lower risk of poverty than the population on average. 
66. Table 23 witnesses also that a considerable population shift that is occurring in Turkey has affected its demographic profile of vulnerable population. There has been a dramatic fall in the average number of children per family. The share of families with three and more children in the population of Turkey has fallen from 49 percent in 1987 to 32 percent in 1994. As children, especially in large families, tend to increase the vulnerability to poverty, reduction in fertility acted as a strong poverty alleviation mechanism. The drop in fertility alone accounts for more than half of the overall reduction of poverty and economic vulnerability risks in Turkey between 1987 and 1994.

67. Chart below suggests that poor have worse housing conditions, and that they own substantially less durables. We do not differentiate between domestically produced and imported durables, between new and worn out goods, but even at this simplest approach get quite striking differences.

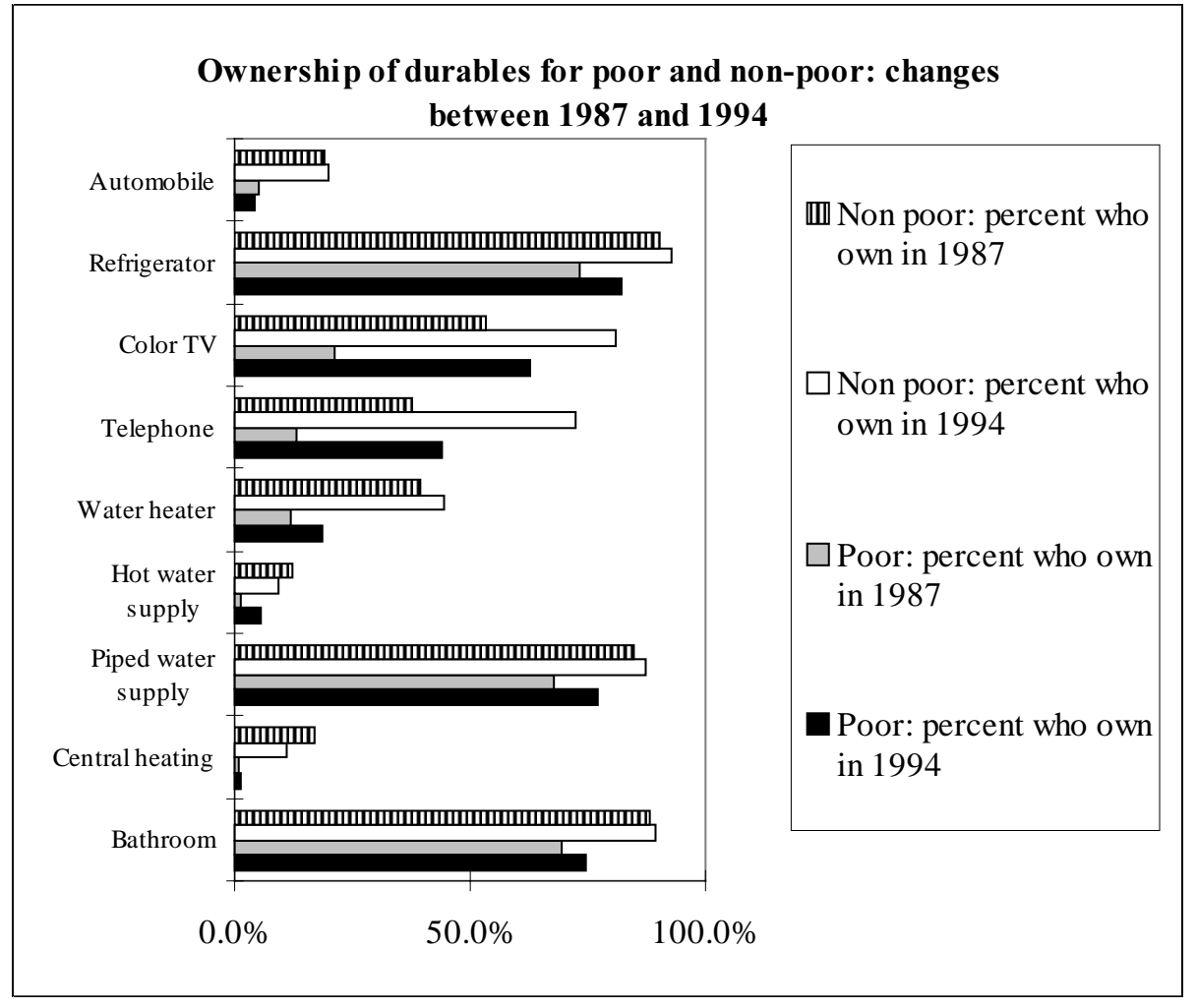

68. The chart shows a considerable progress over time in the ownership of durables, access to water and communications. The progress has also been shared by the poor. But despite this progress the gap between the poor and non-poor remains large. When we add to that that almost 40 percent of the poor live in undeveloped and slum areas which have poor infrastructure and access to basic services, the picture of relative deprivation of a substantial proportion of population is becoming even worse. 


\section{Income and employment opportunities}

69. Ultimately, the living standards depend on earning opportunities. Table 24 below brings the evidence on where the poor and non-poor get their income from. Table 25 focuses on the link between the education and wages, and Table 26 decomposes the gap between the poor and non-poor workers.

70. As revealed by Table 24 the most important source of income for a Turkish household is labor. Poor depend on labor income even to a greater extent than the non-poor - almost $80 \%$ of their income is coming from labor. Therefore earning opportunities are key factor determining living standards.

71. But there is a big discrepancy in the level of total incomes, and in particular - labor incomes - of the non-poor and poor. Table 25 shows that wages for the working poor are on average $44 \%$ less than wages of the non-poor; in addition we know from the survey that the income from self-employment of the poor is $47 \%$ less than the income of the self-employed who is not poor. Part of the reasons for such wide differences is explained in chapter on inequality. Here we are going to concentrate manly of wage income.

Table 24: Income structure of the poor and non-poor

\begin{tabular}{|l|ccc|}
\hline & \multicolumn{2}{|c}{ Poverty status and monthly household incomes } \\
\hline \multicolumn{1}{|c|}{ Source of income } & $\begin{array}{c}\text { Non poor: structure of } \\
\text { household incomes, } \\
\text { percent }\end{array}$ & $\begin{array}{c}\text { Poor: structure of } \\
\text { household incomes, } \\
\text { percent }\end{array}$ & $\begin{array}{c}\text { All households: } \\
\text { structure of incomes, } \\
\text { percent }\end{array}$ \\
\hline Total labor income & & & \\
Wage earnings & $\mathbf{7 2 . 2 \%}$ & $\mathbf{8 0 . 8 \%}$ & $\mathbf{7 3 . 7 \%}$ \\
Income from self-employment & $34.6 \%$ & $40.0 \%$ & $35.6 \%$ \\
Total capital and property income & $37.6 \%$ & $40.7 \%$ & $38.1 \%$ \\
Interest and income from securities & $\mathbf{6 . 0 \%}$ & $\mathbf{2 . 1 \%}$ & $\mathbf{5 . 3 \%}$ \\
Rent and other property income & $2.7 \%$ & $0.7 \%$ & $2.4 \%$ \\
Total transfers & $3.3 \%$ & $1.4 \%$ & $3.0 \%$ \\
State transfers & $\mathbf{1 0 . 1 \%}$ & $\mathbf{7 . 2 \%}$ & $\mathbf{9 . 5 \%}$ \\
Private transfers & $7.9 \%$ & $5.8 \%$ & $7.5 \%$ \\
Other income & $2.2 \%$ & $1.4 \%$ & $2.1 \%$ \\
Total household income & $\mathbf{1 1 . 7 \%}$ & $\mathbf{9 . 9 \%}$ & $\mathbf{1 1 . 4 \%}$ \\
Total monthly household income, TL & $\mathbf{1 0 0 . 0 \%}$ & $\mathbf{1 0 0 . 0} \%$ & $\mathbf{1 0 0 . 0 \%}$ \\
\hline
\end{tabular}

Note: incomes are in average 1994 Central Anatolia prices

72. As the Table 25 shows, there is a large gap in skills between the poor and the non- poor. Workers with primary education or less tend to be poor, and in fact almost 80 percent of poor wage earners are illiterate or have only the primary education. Therefore, part of the different outcomes for the poor and noon-poor on the labor market can be explained by differences in the amount of human capital (education, experience etc.) that the poor and non-poor have.

73. Extending this argument further, we can try to see to what all other personal and job characteristics explain differences in wages between the poor and non-poor. In a framework of earning functions we can predict what would be the level of earnings of the poor if they would have the same returns of their characteristics, as the non-poor. The results are reported in Table 26 below. 
Table 25: Poverty and monthly real wages (in TL) by the level of education

\begin{tabular}{|l|ccc|c|c|c|c|}
\hline & \multicolumn{3}{|c|}{ Wages by poverty status } & \multicolumn{3}{c|}{ Structure wage employment, percent } \\
\hline $\begin{array}{c}\text { Maximum level of } \\
\text { education achieved by } \\
\text { a person }\end{array}$ & Non-Poor & Poor & $\begin{array}{c}\text { All wage } \\
\text { employees }\end{array}$ & Non-Poor & Poor & $\begin{array}{c}\text { All wage } \\
\text { employees }\end{array}$ & $\begin{array}{c}\text { Wage } \\
\text { employees by } \\
\text { level of } \\
\text { education }\end{array}$ \\
\hline All wage employees & $\mathbf{6 , 6 7 4 , 5 5 5}$ & $\mathbf{3 , 6 6 5 , 3 8 3}$ & $\mathbf{5 , 7 0 5 , 1 1 2}$ & $\mathbf{6 7 . 8 \%}$ & $\mathbf{3 2 . 2 \%}$ & $\mathbf{1 0 0 . 0 \%}$ & $\mathbf{1 0 0 . 0 \%}$ \\
illiterate & $3,284,729$ & $2,295,105$ & $2,713,328$ & $42.3 \%$ & $57.7 \%$ & $100.0 \%$ & $5.6 \%$ \\
literate w/o diploma & $4,767,649$ & $3,150,994$ & $3,911,481$ & $47.0 \%$ & $53.0 \%$ & $100.0 \%$ & $2.8 \%$ \\
primary & $5,267,064$ & $3,578,773$ & $4,580,809$ & $59.4 \%$ & $40.6 \%$ & $100.0 \%$ & $50.9 \%$ \\
secondary school & $6,180,306$ & $4,273,725$ & $5,619,980$ & $70.6 \%$ & $29.4 \%$ & $100.0 \%$ & $10.5 \%$ \\
vocational school & $7,307,721$ & $4,453,059$ & $6,407,549$ & $68.5 \%$ & $31.5 \%$ & $100.0 \%$ & $0.4 \%$ \\
high school & $7,169,848$ & $4,825,969$ & $6,755,762$ & $82.3 \%$ & $17.7 \%$ & $100.0 \%$ & $15.7 \%$ \\
vocational at high sc. & $7,768,707$ & $4,660,668$ & $7,398,132$ & $88.1 \%$ & $11.9 \%$ & $100.0 \%$ & $3.2 \%$ \\
university & $11,062,470$ & $6,311,368$ & $10,834,871$ & $95.2 \%$ & $4.8 \%$ & $100.0 \%$ & $10.8 \%$ \\
aster \& doctorate & $13,738,302$ &. & $13,738,302$ & $100.0 \%$ & $0.0 \%$ & $100.0 \%$ & $0.3 \%$ \\
\hline
\end{tabular}

Note: Wages are in average 1994 Central Anatolia prices

74. Extending this argument further, we can try to see to what all other personal and job characteristics explain differences in wages between the poor and non-poor. In a framework of earning functions we can predict what would be the level of earnings of the poor if they would have the same returns of their characteristics, as the non-poor. The results are reported in Table 26 below.

Table 26: Blinder-Oaxaca wage gap decomposition between the poor and the non-poor

\begin{tabular}{|c|c|c|c|}
\hline Decomposition approach & $\begin{array}{l}\text { Wage gap between } \\
\text { poor and non-poor, } \\
\text { log points }\end{array}$ & $\begin{array}{l}\text { of which: } \\
\text { difference in } \\
\text { endowments }\end{array}$ & $\begin{array}{l}\text { difference in } \\
\text { treatment }\end{array}$ \\
\hline Crude (observed) wage gap & .458 & & \\
\hline Returns for non-poor applied to poors' characteristics & .481 & .414 & .067 \\
\hline Returns of the poor applied to non-poor characteristics & .115 & .071 & 044 \\
\hline
\end{tabular}

75. This predicted wage outcome does show a very big discrepancy between the poor and nonpoor in the wage levels. Controlling for differences in mean characteristics, the gap is even larger that the observed. On the other hand, if we assume that the non-poor would have the same return as poor on their skills, we obtain a gap in predicted wages that is very much below the actually observed difference in wage outcomes, but still show a substantial gap. Both estimates shown in the table are legitimate "brackets" for the "net" gap (accounting for differences in the endowments). It shows that there is a discrimination against the poor, but most of the differences between labor incomes of poor and non-poor is explained by differences in endowments: poor have lower education, lower experience and have insecure casual low-productive jobs.

76. Though on average the gap between the poor and non-poor workers has shrunk somewhat over time (1987-1994, by 5 percent) poor workers with primary education or less have experienced a deterioration of their relative pay. As the sources of incomes for poor households headed by casual workers have become less diversified, their ability to strike the balance between end and needs has become more fragile. 


\section{Transfers and social safety nets}

77. As we have seen in Table 24 above, the structure of incomes is very different for the poor and the non-poor, and transfers are part of this difference. Chart 4 below brings additional evidence of the very different coverage of the poor and non-poor by the social safety net.

78. As shown in Table 24 transfers from the State constitute relatively small part of Turkish households' incomes. Main transfer program are different types of pensions and there are mostly non-poor who benefit from them. The share of private transfers is really very small both for the poor and non-poor. It is to note, though, that the aid from relatives and aid associations has marginally better targeting towards the poor than any government programs. But the share of the poor covered by this private transfers is very small; just above 10 percent.

79. This suggests that neither the State, nor the civil society or inter-family relationships play an important role as safety net. This in combination with the evidence presented on the predominance of extended families suggests intra-family ties are playing the predominant role as safety net in Turkey. This system makes those who can no longer rely on their relatives particularly vulnerable. It is a striking evidence that close to 70 percent of the poor are not covered with any type of medical insurance.

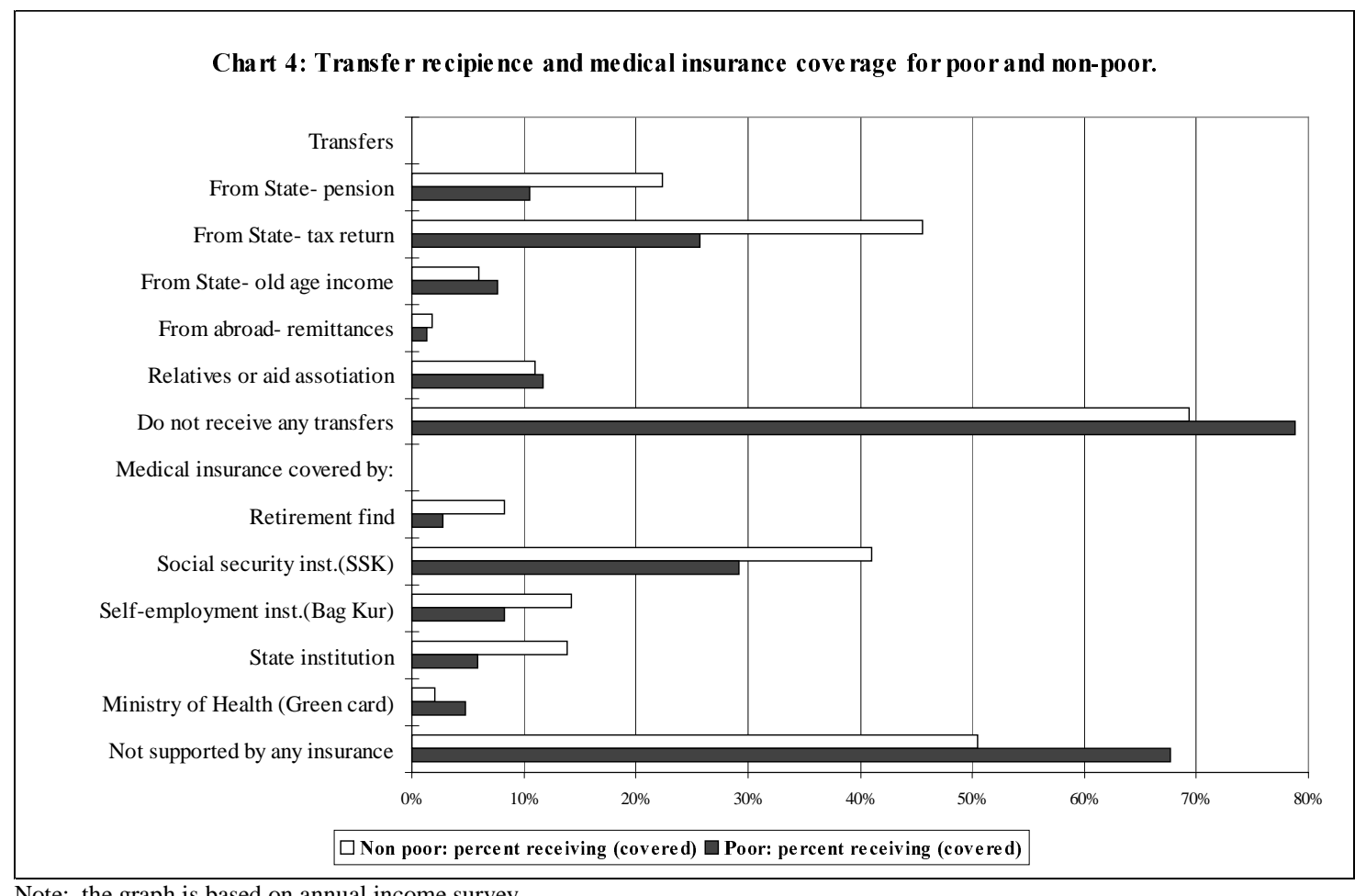

Note: the graph is based on annual income survey.

80. Chart 4 also shows that there are only two small-scale Government programs that favor poor more than the rich: old age pensions and Green cards program run by the Ministry of Health. However, these two are very modest in size and have a minimal impact on the living standards of the poor. 


\section{Conclusion}

81. The ultimate objective of poverty analysis is not to count people who fall below a certain line, but to find reasons of why some groups of the population do not benefit fully from the economic opportunities or are more vulnerable to shocks. What we have discovered in this profile, is that human capital and employment are key determinants of living standards of a Turkish household. This finding is robust and holds across many modifications of the methodology that are discussed in the Technical annex. The labor market factors were operating in 1994 almost exactly as they were in 1987. Therefore, despite some progress, the relative position of unprivileged groups has not improved by much in this period. The key forces behind changes of poverty and vulnerability were macroeconomic and demographic factors. They were working in the opposite direction: while inflation and rise in unemployment were pushing the poverty up, the fall in fertility, rising educational attainment and migration were operating towards reducing poverty. 
Table Annexes

Table 3: Poverty profile by regions

\begin{tabular}{|c|c|c|c|c|c|c|c|c|c|c|}
\hline & \multicolumn{5}{|c|}{ Poverty indicators } & \multicolumn{5}{|c|}{ Structure of the total, percent } \\
\hline Region & $\begin{array}{l}\text { Incidence of } \\
\text { vulnerability }\end{array}$ & $\begin{array}{l}\text { Headcount for } \\
\text { poor }\end{array}$ & $\begin{array}{c}\text { Average } \\
\text { shortfall of the } \\
\text { poor }\end{array}$ & $\begin{array}{c}\text { Depth of } \\
\text { vulnerability }\end{array}$ & $\begin{array}{c}\text { Severity of } \\
\text { vulnerability }\end{array}$ & Population & $\begin{array}{c}\text { Poor } \\
\text { population }\end{array}$ & $\begin{array}{l}\text { Very poor } \\
\text { population }\end{array}$ & Depth & Severity \\
\hline Marmara & 0.336 & 0.055 & 0.300 & 0.101 & 0.042 & $24.7 \%$ & $22.8 \%$ & $18.5 \%$ & $22.7 \%$ & $22.8 \%$ \\
\hline Aegean & 0.245 & 0.023 & 0.251 & 0.062 & 0.022 & $13.6 \%$ & $9.2 \%$ & $4.3 \%$ & $7.6 \%$ & $6.6 \%$ \\
\hline Mediterranean & 0.382 & 0.081 & 0.308 & 0.118 & 0.050 & $12.8 \%$ & $13.4 \%$ & $14.2 \%$ & $13.7 \%$ & $13.9 \%$ \\
\hline Central Anatolia & 0.390 & 0.086 & 0.318 & 0.124 & 0.055 & $17.2 \%$ & $18.5 \%$ & $20.3 \%$ & $19.5 \%$ & $20.7 \%$ \\
\hline Black Sea & 0.259 & 0.043 & 0.265 & 0.068 & 0.025 & $13.4 \%$ & $9.6 \%$ & $8.0 \%$ & $8.4 \%$ & $7.5 \%$ \\
\hline East Anatolia & 0.500 & 0.145 & 0.334 & 0.167 & 0.074 & $8.8 \%$ & $12.2 \%$ & $17.5 \%$ & $13.5 \%$ & $14.4 \%$ \\
\hline $\begin{array}{l}\text { South East } \\
\text { Anatolia }\end{array}$ & 0.542 & 0.130 & 0.306 & 0.166 & 0.068 & $9.6 \%$ & $14.3 \%$ & $17.1 \%$ & $14.5 \%$ & $14.2 \%$ \\
\hline Total & 0.363 & 0.073 & 0.301 & 0.109 & 0.046 & $100.0 \%$ & $100.0 \%$ & $100.0 \%$ & $100.0 \%$ & $100.0 \%$ \\
\hline Rural & 0.348 & 0.085 & 0.293 & 0.102 & 0.042 & $46.5 \%$ & $44.6 \%$ & $54.6 \%$ & $43.4 \%$ & $42.3 \%$ \\
\hline Urban & 0.375 & 0.062 & 0.308 & 0.116 & 0.049 & $53.5 \%$ & $55.4 \%$ & $45.4 \%$ & $56.6 \%$ & $57.7 \%$ \\
\hline
\end{tabular}


Table 3a: Decomposition of poverty change between 1987 and 1994 by regions and locations

\begin{tabular}{|c|c|c|c|c|c|c|c|c|}
\hline \multirow[b]{2}{*}{ Region } & \multirow[b]{2}{*}{$\begin{array}{l}\text { Incidence } \\
\text { of poverty } \\
\text { in } 1987\end{array}$} & \multirow[b]{2}{*}{$\begin{array}{c}\text { Incidence of } \\
\text { poverty in } \\
1994\end{array}$} & \multirow[b]{2}{*}{$\begin{array}{c}\text { Contribution to } \\
\text { poverty change in } \\
\text { the country, points }\end{array}$} & \multicolumn{3}{|c|}{ of which*: } & \multicolumn{2}{|c|}{ Memo: absolute change } \\
\hline & & & & $\begin{array}{l}\text { due to change } \\
\text { in poverty risk }\end{array}$ & $\begin{array}{c}\text { due to } \\
\text { population } \\
\text { shifts }\end{array}$ & $\begin{array}{c}\text { interaction } \\
\text { term }\end{array}$ & $\begin{array}{l}\text { Change in the } \\
\text { population, } \\
\text { thousand }\end{array}$ & $\begin{array}{l}\text { Change in the } \\
\text { number of } \\
\text { poor, thousand }\end{array}$ \\
\hline $\begin{array}{l}\text { Marmara } \\
\text { Aegean } \\
\text { Mediterranean } \\
\text { Central Anatolia } \\
\text { Black Sea } \\
\text { East Anatolia } \\
\text { South East Anatolia }\end{array}$ & $\begin{array}{c}2.2 \% \\
6.9 \% \\
8.0 \% \\
11.8 \% \\
9.7 \% \\
16.8 \% \\
22.5 \% \\
\end{array}$ & $\begin{array}{l}5.5 \% \\
2.3 \% \\
8.1 \% \\
8.6 \% \\
4.3 \% \\
14.5 \% \\
13.0 \% \\
\end{array}$ & $\begin{array}{l}+0.9 \% \\
-0.7 \% \\
+0.3 \% \\
-1.1 \% \\
-0.5 \% \\
-0.8 \% \\
-0.7 \% \\
\end{array}$ & $\begin{array}{l}+0.7 \% \\
-0.7 \% \\
+0.0 \% \\
-0.7 \% \\
-0.6 \% \\
-0.3 \% \\
-0.8 \% \\
\end{array}$ & $\begin{array}{l}+0.1 \% \\
-0.1 \% \\
+0.2 \% \\
-0.6 \% \\
+0.2 \% \\
-0.6 \% \\
+0.2 \% \\
\end{array}$ & $\begin{array}{l}+0.1 \% \\
+0.0 \% \\
+0.0 \% \\
+0.2 \% \\
-0.1 \% \\
+0.1 \% \\
-0.1 \% \\
\end{array}$ & $\begin{array}{c}+3,304 \\
+471 \\
+2,432 \\
-1,432 \\
+1,974 \\
-1,200 \\
+1,057 \\
\end{array}$ & $\begin{array}{l}+556 \\
-339 \\
+203 \\
-500 \\
-236 \\
-326 \\
-303 \\
\end{array}$ \\
\hline Total & $10.0 \%$ & $7.3 \%$ & $-2.7 \%$ & $-2.4 \%$ & $-0.5 \%$ & $+0.2 \%$ & $+6,607$ & -945 \\
\hline $\begin{array}{l}\text { Rural } \\
\text { Urban }\end{array}$ & $\begin{array}{c}14.4 \% \\
5.0 \% \\
\end{array}$ & $\begin{array}{l}8.5 \% \\
6.2 \% \\
\end{array}$ & $\begin{array}{l}-3.6 \% \\
+0.9 \% \\
\end{array}$ & $\begin{array}{r}-3.1 \% \\
+0.6 \% \\
\end{array}$ & $\begin{array}{l}-0.9 \% \\
+0.3 \% \\
\end{array}$ & $\begin{array}{l}+0.4 \% \\
+0.1 \% \\
\end{array}$ & $\begin{array}{c}-195 \\
+6,803 \\
\end{array}$ & $\begin{array}{c}-1,658 \\
+713 \\
\end{array}$ \\
\hline Total & $10.0 \%$ & $7.3 \%$ & $-2.7 \%$ & $-2.6 \%$ & $-0.6 \%$ & $+0.4 \%$ & $+6,607$ & -945 \\
\hline
\end{tabular}

* Note: to decompose changes of poverty incidence we 1) apply changes in the risk of poverty to the initial (1987) population structure ( this component is called "poverty risk

change); 2) apply initial poverty incidence to the changes in the population structure ("population shifts); 3) allow simultaneous change in poverty risk and population structure (interaction term). 
Table 4: Poverty and location: developed and undeveloped areas in cities.

\begin{tabular}{|l|cc|c|cc|}
\hline \multicolumn{1}{|c|}{$\begin{array}{c}\text { Street properties for urban } \\
\text { households }\end{array}$} & $\begin{array}{c}\text { Incidence of } \\
\text { vulnerability }\end{array}$ & $\begin{array}{c}\text { Headcount for } \\
\text { poor }\end{array}$ & Population & $\begin{array}{c}\text { Vulnerable } \\
\text { population }\end{array}$ & $\begin{array}{c}\text { Poor } \\
\text { population }\end{array}$ \\
\hline Developed & 0.252 & 0.028 & $25.2 \%$ & $17.6 \%$ & $9.8 \%$ \\
Undeveloped and slum areas & 0.478 & 0.090 & $28.7 \%$ & $37.8 \%$ & $35.6 \%$ \\
ALL URBAN & 0.372 & 0.061 & $54.0 \%$ & $55.4 \%$ & $45.4 \%$ \\
ALL RURAL & 0.348 & 0.085 & $46.0 \%$ & $44.6 \%$ & $54.6 \%$ \\
ALL HOUSEHOLDS & $\mathbf{0 . 3 6 3}$ & $\mathbf{0 . 0 7 3}$ & $\mathbf{1 0 0 . 0 \%}$ & $\mathbf{1 0 0 . 0 \%}$ & $\mathbf{1 0 0 . 0 \%}$ \\
\hline
\end{tabular}

Table 7: Poverty risks for individuals by the level of education.

\begin{tabular}{|c|c|c|c|c|c|}
\hline & \multicolumn{2}{|c|}{ Poverty indicators } & \multicolumn{3}{|c|}{ Structure, percent } \\
\hline $\begin{array}{c}\text { Maximum level of education } \\
\text { achieved by a person }\end{array}$ & $\begin{array}{l}\text { Incidence of } \\
\text { vulnerability }\end{array}$ & Headcount for poor & Population & $\begin{array}{l}\text { Vulnerable } \\
\text { population }\end{array}$ & Poor population \\
\hline ADULTS ( $>=25$ y.o.) & 0.314 & 0.057 & $47.9 \%$ & $41.5 \%$ & $37.5 \%$ \\
\hline illiterate & 0.417 & 0.099 & $12.0 \%$ & $13.8 \%$ & $16.4 \%$ \\
\hline literate w/o diploma & 0.349 & 0.063 & $3.4 \%$ & $3.2 \%$ & $2.9 \%$ \\
\hline primary & 0.324 & 0.052 & $23.0 \%$ & $20.5 \%$ & $16.5 \%$ \\
\hline secondary school & 0.233 & 0.026 & $3.0 \%$ & $1.9 \%$ & $1.0 \%$ \\
\hline vocational school & 0.176 & 0.008 & $0.1 \%$ & $0.0 \%$ & $0.0 \%$ \\
\hline high school & 0.155 & 0.012 & $3.6 \%$ & $1.5 \%$ & $0.6 \%$ \\
\hline vocational at high sc. & 0.096 & 0.004 & $0.6 \%$ & $0.2 \%$ & $0.0 \%$ \\
\hline university & 0.041 & 0.002 & $2.2 \%$ & $0.2 \%$ & $0.1 \%$ \\
\hline master \& doctorate & 0.000 & 0.000 & $0.1 \%$ & $0.0 \%$ & $0.0 \%$ \\
\hline YOUTH (6-24 yrs.) & 0.402 & 0.085 & $41.0 \%$ & $45.4 \%$ & $48.0 \%$ \\
\hline illiterate & 0.551 & 0.136 & $4.0 \%$ & $6.1 \%$ & $7.5 \%$ \\
\hline literate w/o diploma & 0.456 & 0.107 & $10.7 \%$ & $13.4 \%$ & $15.7 \%$ \\
\hline primary & 0.407 & 0.084 & $18.0 \%$ & $20.1 \%$ & $20.8 \%$ \\
\hline secondary school & 0.298 & 0.045 & $4.4 \%$ & $3.7 \%$ & $2.7 \%$ \\
\hline vocational school & 0.237 & 0.037 & $0.2 \%$ & $0.1 \%$ & $0.1 \%$ \\
\hline high school & 0.205 & 0.023 & $3.0 \%$ & $1.7 \%$ & $1.0 \%$ \\
\hline vocational at high sc. & 0.176 & 0.023 & $0.4 \%$ & $0.2 \%$ & $0.1 \%$ \\
\hline university & 0.142 & 0.000 & $0.2 \%$ & $0.1 \%$ & $0.0 \%$ \\
\hline master \& doctorate & 0.000 & 0.000 & $0.0 \%$ & $0.0 \%$ & $0.0 \%$ \\
\hline CHILDREN(<6 y.o.) & 0.426 & 0.095 & $11.1 \%$ & $13.1 \%$ & $14.5 \%$ \\
\hline TOTAL & 0.363 & 0.073 & $100.0 \%$ & $100.0 \%$ & $100.0 \%$ \\
\hline
\end{tabular}


Table 8: Educational status of children 12-15 years old, by regions

\begin{tabular}{|l|ccccccc|}
\hline \multicolumn{1}{|c|}{ Region } & $\begin{array}{c}\text { Illiterate to total, } \\
\text { percent }\end{array}$ & $\begin{array}{c}\text { Literate without } \\
\text { diploma, } \\
\text { percent }\end{array}$ & $\begin{array}{c}\text { Primary school } \\
\text { completed, } \\
\text { percent }\end{array}$ & $\begin{array}{c}\text { Junior high } \\
\text { school }\end{array}$ & $\begin{array}{c}\text { Vocational } \\
\text { secondary, } \\
\text { percent }\end{array}$ & $\begin{array}{c}\text { High school } \\
\text { Vocational at } \\
\text { high school } \\
\text { level }\end{array}$ \\
\hline Marmara & $1.4 \%$ & $5.4 \%$ & $75.7 \%$ & $16.5 \%$ & $0.4 \%$ & $0.3 \%$ & $0.2 \%$ \\
Aegean & $1.4 \%$ & $5.7 \%$ & $72.9 \%$ & $18.8 \%$ & $0.5 \%$ & $0.6 \%$ & $0.1 \%$ \\
Mediterranean & $3.1 \%$ & $9.6 \%$ & $72.1 \%$ & $14.4 \%$ & $0.6 \%$ & $0.3 \%$ & $0.0 \%$ \\
Central Anatolia & $0.4 \%$ & $9.7 \%$ & $71.8 \%$ & $16.2 \%$ & $1.1 \%$ & $0.6 \%$ & $0.2 \%$ \\
Black Sea & $1.7 \%$ & $7.1 \%$ & $75.2 \%$ & $14.5 \%$ & $0.7 \%$ & $0.8 \%$ & $0.0 \%$ \\
East Anatolia & $8.1 \%$ & $10.0 \%$ & $66.8 \%$ & $14.2 \%$ & $0.2 \%$ & $0.7 \%$ & $0.0 \%$ \\
South East Anatolia & $11.4 \%$ & $12.3 \%$ & $63.5 \%$ & $11.3 \%$ & $0.8 \%$ & $0.6 \%$ & $0.1 \%$ \\
Total & $\mathbf{3 . 4 \%}$ & $\mathbf{8 . 2 \%}$ & $\mathbf{7 1 . 8 \%}$ & $\mathbf{1 5 . 3 \%}$ & $\mathbf{0 . 6 \%}$ & $\mathbf{0 . 5 \%}$ & $\mathbf{0 . 1 \%}$ \\
\hline
\end{tabular}


Table 9: Location and education of children 12-15 years old

\begin{tabular}{|c|c|c|c|c|c|}
\hline & \multicolumn{2}{|c|}{ Percent of children in the area who: } & \multicolumn{3}{|c|}{ Structure, percent of } \\
\hline Place of living for children & $\begin{array}{cc}\text { are no longer in } & \mathrm{a} \\
\text { school } & \mathrm{n}\end{array}$ & $\begin{array}{l}\text { are no longer in school and have } \\
\text { not completed primary education }\end{array}$ & $\begin{array}{l}\text { All children } \\
12-15 \text { years } \\
\text { old }\end{array}$ & $\begin{array}{l}\text { All children } \\
\text { no longer in } \\
\text { school }\end{array}$ & $\begin{array}{c}\text { All children no longer in } \\
\text { school without primary } \\
\text { education }\end{array}$ \\
\hline Developed urban areas & $18.5 \%$ & $0.8 \%$ & $23.0 \%$ & $11.0 \%$ & $3.8 \%$ \\
\hline Undeveloped and slum areas & $32.9 \%$ & $1.6 \%$ & $29.0 \%$ & $24.7 \%$ & $9.9 \%$ \\
\hline ALL URBAN CHILDREN, 12-15 y.o. & $26.6 \%$ & $2.8 \%$ & $52.4 \%$ & $36.0 \%$ & $30.2 \%$ \\
\hline ALL RURAL CHILDREN, 12-15 YO & $51.9 \%$ & $7.1 \%$ & $47.6 \%$ & $64.0 \%$ & $69.8 \%$ \\
\hline ALL CHILDREN 12-15 y.o & $38.7 \%$ & $4.8 \%$ & $100.0 \%$ & $100.0 \%$ & $100.0 \%$ \\
\hline
\end{tabular}


Table 12: Decomposition of poverty change by labor market status

\begin{tabular}{|c|c|c|c|c|c|c|}
\hline \multirow[b]{2}{*}{ Individual characteristic } & \multirow{2}{*}{\multicolumn{2}{|c|}{$\begin{array}{c}\text { Incidence of } \begin{array}{c}\text { Incidence of } \\
\text { poverty in poverty in } 1994 \\
1987\end{array}\end{array}$}} & \multirow[b]{2}{*}{$\begin{array}{l}\text { Contribution to } \\
\text { poverty change in } \\
\text { the country, } \\
\text { points }\end{array}$} & \multicolumn{3}{|c|}{ of which } \\
\hline & & & & $\begin{array}{l}\text { due to } \\
\text { change in } \\
\text { poverty risk }\end{array}$ & $\begin{array}{l}\text { due to } \\
\text { population } \\
\text { shifts }\end{array}$ & $\begin{array}{l}\text { interaction } \\
\text { term }\end{array}$ \\
\hline Wage employee & $6 \%$ & $5 \%$ & $-0.0 \%$ & $-0.1 \%$ & $+0.1 \%$ & $-0.0 \%$ \\
\hline Employer & $1 \%$ & $1 \%$ & $-0.0 \%$ & $-0.0 \%$ & $+0.0 \%$ & $-0.0 \%$ \\
\hline Self-employed & $11 \%$ & $7 \%$ & $-0.4 \%$ & $-0.3 \%$ & $-0.1 \%$ & $+0.0 \%$ \\
\hline Unpaid family worker & $11 \%$ & $8 \%$ & $-0.7 \%$ & $-0.5 \%$ & $-0.3 \%$ & $+0.1 \%$ \\
\hline Unemployed & $16 \%$ & $10 \%$ & $+0.2 \%$ & $-0.1 \%$ & $+0.4 \%$ & $-0.2 \%$ \\
\hline Retired & $4 \%$ & $1 \%$ & $-0.1 \%$ & $-0.1 \%$ & $+0.0 \%$ & $-0.0 \%$ \\
\hline Rentier & $6 \%$ & $4 \%$ & $-0.0 \%$ & $-0.0 \%$ & $-0.0 \%$ & $+0.0 \%$ \\
\hline Elderly & $13 \%$ & $9 \%$ & $-0.1 \%$ & $-0.1 \%$ & $+0.0 \%$ & $-0.0 \%$ \\
\hline CHILDREN (<12 y.o.) & $13 \%$ & $10 \%$ & $-1.2 \%$ & $-0.9 \%$ & $-0.5 \%$ & $+0.1 \%$ \\
\hline Other not employed & $8 \%$ & $6 \%$ & $-0.4 \%$ & $-0.6 \%$ & $+0.2 \%$ & $-0.1 \%$ \\
\hline TOTAL & $10 \%$ & $7 \%$ & $-2.7 \%$ & $-2.6 \%$ & $-0.1 \%$ & $-0.0 \%$ \\
\hline
\end{tabular}


Table 13: Poverty risks and employment status of individuals

\begin{tabular}{|l|cc|c|cc|}
\hline & \multicolumn{2}{|c|}{ Poverty indicators } & \multicolumn{3}{c|}{ Structure, percent } \\
\hline $\begin{array}{l}\text { Employment status and } \\
\text { reasons for non- } \\
\text { employment of a person }\end{array}$ & $\begin{array}{c}\text { Incidence of } \\
\text { vulnerability }\end{array}$ & $\begin{array}{c}\text { Headcount for the } \\
\text { poor }\end{array}$ & Population & $\begin{array}{c}\text { Vulnerable } \\
\text { population }\end{array}$ & $\begin{array}{c}\text { Poor } \\
\text { population }\end{array}$ \\
\hline EMPLOYED & $\mathbf{0 . 3 3 3}$ & $\mathbf{0 . 0 6 4}$ & $\mathbf{3 8 . 3 \%}$ & $\mathbf{3 5 . 2 \%}$ & $\mathbf{3 3 . 9 \%}$ \\
regular employee & 0.309 & 0.037 & $11.1 \%$ & $9.5 \%$ & $5.7 \%$ \\
casual worker & 0.584 & 0.148 & $3.6 \%$ & $5.7 \%$ & $7.2 \%$ \\
employer & 0.169 & 0.013 & $1.6 \%$ & $0.7 \%$ & $0.3 \%$ \\
self-employed & 0.400 & 0.095 & $10.2 \%$ & $11.3 \%$ & $13.3 \%$ \\
unpaid family worker & 0.357 & 0.080 & $11.3 \%$ & $11.1 \%$ & $12.4 \%$ \\
seasonal worker & 0.570 & 0.159 & $0.5 \%$ & $0.9 \%$ & $1.2 \%$ \\
NOT EMPLOYED & $\mathbf{0 . 3 4 0}$ & $\mathbf{0 . 0 6 2}$ & $\mathbf{3 7 . 1 \%}$ & $\mathbf{3 4 . 7 \%}$ & $\mathbf{3 1 . 8 \%}$ \\
unemployed & 0.455 & 0.103 & $4.2 \%$ & $5.2 \%$ & $5.9 \%$ \\
student & 0.326 & 0.056 & $9.5 \%$ & $8.6 \%$ & $7.3 \%$ \\
housewife & 0.340 & 0.058 & $17.1 \%$ & $16.0 \%$ & $13.7 \%$ \\
disabled & 0.442 & 0.120 & $0.3 \%$ & $0.4 \%$ & $0.5 \%$ \\
ill & 0.410 & 0.110 & $0.4 \%$ & $0.4 \%$ & $0.6 \%$ \\
retired & 0.179 & 0.010 & $2.8 \%$ & $1.4 \%$ & $0.4 \%$ \\
rentier & 0.216 & 0.040 & $0.3 \%$ & $0.2 \%$ & $0.1 \%$ \\
elderly & 0.373 & 0.094 & $2.1 \%$ & $2.2 \%$ & $2.7 \%$ \\
other & 0.331 & 0.092 & $0.4 \%$ & $0.4 \%$ & $0.5 \%$ \\
CHILDREN $(<\mathbf{1 2}$ y.o.) & $\mathbf{0 . 4 4 3}$ & $\mathbf{0 . 1 0 2}$ & $\mathbf{2 4 . 6 \%}$ & $\mathbf{3 0 . 0 \%}$ & $\mathbf{3 4 . 3 \%}$ \\
\hline TOTAL & $\mathbf{0 . 3 6 3}$ & $\mathbf{0 . 0 7 3}$ & $\mathbf{1 0 0 . 0 \%}$ & $\mathbf{1 0 0 . 0 \%}$ & $\mathbf{1 0 0 . 0 \%}$ \\
\hline & & & & & \\
\hline & & & & & \\
\hline
\end{tabular}

Table 14: Ownership form and poverty risk for wage employees.

\begin{tabular}{|l|cc|c|cc}
\hline Ownership form of the establishment & $\begin{array}{c}\text { Incidence of } \\
\text { economic } \\
\text { vulnerability }\end{array}$ & $\begin{array}{c}\text { Headcount for } \\
\text { poor }\end{array}$ & Population & $\begin{array}{c}\text { Vulnerable } \\
\text { population }\end{array}$ & $\begin{array}{c}\text { Poor } \\
\text { population }\end{array}$ \\
\hline Regular and casual employees & $\mathbf{0 . 3 1 3}$ & $\mathbf{0 . 0 5 4}$ & $\mathbf{1 4 . 1 \%}$ & $\mathbf{1 2 . 2 \%}$ & $\mathbf{1 0 . 5 \%}$ \\
state sector & 0.176 & 0.013 & $4.8 \%$ & $2.3 \%$ & $0.9 \%$ \\
private sector & 0.382 & 0.064 & $9.4 \%$ & $9.9 \%$ & $8.2 \%$ \\
TOTAL EMPLOYED & 0.333 & 0.064 & $38.3 \%$ & $35.2 \%$ & $33.9 \%$ \\
TOTAL POPULATION & $\mathbf{0 . 3 6 3}$ & $\mathbf{0 . 0 7 3}$ & $\mathbf{1 0 0 . 0 \%}$ & $\mathbf{1 0 0 . 0 \%}$ & $\mathbf{1 0 0 . 0 \%}$ \\
\hline
\end{tabular}


Table 15: Poverty risk and social security coverage for wage employees

\begin{tabular}{|l|cc|c|cc|}
\hline \multicolumn{1}{|c|}{$\begin{array}{c}\text { Social security coverage for } \\
\text { employed person }\end{array}$} & $\begin{array}{c}\text { Incidence of } \\
\text { vulnerability }\end{array}$ & $\begin{array}{c}\text { Headcount for } \\
\text { poor }\end{array}$ & Population & $\begin{array}{c}\text { Vulnerable } \\
\text { population }\end{array}$ & $\begin{array}{c}\text { Poor } \\
\text { population }\end{array}$ \\
\hline EMPLOYED & 0.333 & 0.064 & $38.3 \%$ & $35.2 \%$ & $33.9 \%$ \\
All wage employees & 0.313 & 0.054 & $14.1 \%$ & $12.2 \%$ & $10.5 \%$ \\
insured by SSK & 0.276 & 0.024 & $5.7 \%$ & $4.3 \%$ & $1.9 \%$ \\
insured by contract & 0.197 & 0.016 & $0.4 \%$ & $0.2 \%$ & $0.1 \%$ \\
retirement fund permanent & 0.149 & 0.011 & $2.6 \%$ & $1.1 \%$ & $0.4 \%$ \\
retirement fund by contract & 0.155 & 0.001 & $0.2 \%$ & $0.1 \%$ & $0.0 \%$ \\
NOT REGISTERED & 0.454 & 0.095 & $5.1 \%$ & $6.4 \%$ & $6.7 \%$ \\
NOT EMPLOYED & 0.340 & 0.062 & $37.1 \%$ & $34.7 \%$ & $31.8 \%$ \\
CHILDREN (<12 y.o.) & 0.443 & 0.102 & $24.6 \%$ & $30.0 \%$ & $34.3 \%$ \\
TOTAL & $\mathbf{0 . 3 6 3}$ & $\mathbf{0 . 0 7 3}$ & $\mathbf{1 0 0 . 0 \%}$ & $\mathbf{1 0 0 . 0 \%}$ & $\mathbf{1 0 0 . 0 \%}$ \\
\hline
\end{tabular}


Table 16: Poverty profile by sector of employment for household head

\begin{tabular}{|c|c|c|c|c|c|c|c|c|c|c|}
\hline \multirow[b]{2}{*}{$\begin{array}{c}\text { Sector of } \\
\text { employment of } \\
\text { household head }\end{array}$} & \multicolumn{5}{|c|}{ Poverty indicators } & \multicolumn{5}{|c|}{ Structure and decomposition, percent } \\
\hline & $\begin{array}{l}\text { Incidence of } \\
\text { vulnerability }\end{array}$ & $\begin{array}{l}\text { Headcount for } \\
\text { poor }\end{array}$ & $\begin{array}{l}\text { Average } \\
\text { shortfall of the } \\
\text { poor }\end{array}$ & $\begin{array}{c}\text { Depth of } \\
\text { vulnerability }\end{array}$ & $\begin{array}{c}\text { Severity of } \\
\text { vulnerability }\end{array}$ & Population & $\begin{array}{l}\text { Vulnerable } \\
\text { population }\end{array}$ & $\begin{array}{c}\text { Poor } \\
\text { population }\end{array}$ & Depth & Severity \\
\hline EMPLOYED & 0.371 & 0.074 & 0.301 & 0.112 & 0.046 & $86.3 \%$ & $88.3 \%$ & $88.3 \%$ & $88.1 \%$ & $87.5 \%$ \\
\hline agriculture & 0.418 & 0.106 & 0.303 & 0.127 & 0.052 & $28.6 \%$ & $33.0 \%$ & $41.8 \%$ & $33.1 \%$ & $32.7 \%$ \\
\hline mining & 0.283 & 0.026 & 0.283 & 0.080 & 0.030 & $0.9 \%$ & $0.7 \%$ & $0.3 \%$ & $0.7 \%$ & $0.6 \%$ \\
\hline manufacturing & 0.357 & 0.049 & 0.304 & 0.109 & 0.045 & $12.1 \%$ & $11.9 \%$ & $8.2 \%$ & $12.0 \%$ & $11.9 \%$ \\
\hline power, water, gas & 0.183 & 0.025 & 0.208 & 0.038 & 0.013 & $0.4 \%$ & $0.2 \%$ & $0.1 \%$ & $0.2 \%$ & $0.1 \%$ \\
\hline construction & 0.496 & 0.117 & 0.331 & 0.164 & 0.073 & $7.6 \%$ & $10.4 \%$ & $12.3 \%$ & $11.4 \%$ & $12.2 \%$ \\
\hline trade & 0.346 & 0.063 & 0.301 & 0.104 & 0.044 & $15.8 \%$ & $15.1 \%$ & $13.6 \%$ & $15.0 \%$ & $15.2 \%$ \\
\hline transport & 0.370 & 0.062 & 0.296 & 0.110 & 0.045 & $5.8 \%$ & $5.9 \%$ & $5.0 \%$ & $5.8 \%$ & $5.7 \%$ \\
\hline finance $\&$ banking & 0.189 & 0.000 & 0.206 & 0.039 & 0.010 & $0.6 \%$ & $0.3 \%$ & $0.0 \%$ & $0.2 \%$ & $0.1 \%$ \\
\hline other services & 0.270 & 0.035 & 0.270 & 0.073 & 0.029 & $14.4 \%$ & $10.7 \%$ & $6.9 \%$ & $9.6 \%$ & $9.0 \%$ \\
\hline NOT EMPLOYED & 0.310 & 0.062 & 0.307 & 0.095 & 0.042 & $13.7 \%$ & $11.7 \%$ & $11.7 \%$ & $11.9 \%$ & $12.5 \%$ \\
\hline TOTAL & 0.363 & 0.073 & 0.301 & 0.109 & 0.046 & $100.0 \%$ & $100.0 \%$ & $100.0 \%$ & $100.0 \%$ & $100.0 \%$ \\
\hline
\end{tabular}


Table 19: Poverty profile by dominant status of household heads employment for each sector

\begin{tabular}{|c|c|c|c|c|c|c|c|c|c|c|}
\hline & \multicolumn{5}{|c|}{ Poverty indicators } & \multicolumn{5}{|c|}{ Structure and decomposition, percent } \\
\hline $\begin{array}{l}\text { Sector and dominant status of } \\
\text { employment of household head }\end{array}$ & $\begin{array}{l}\text { Incidence of } \\
\text { vulnerability }\end{array}$ & $\begin{array}{l}\text { Headcount for } \\
\text { poor }\end{array}$ & $\begin{array}{c}\text { Average shortfall of } \\
\text { the poor }\end{array}$ & $\begin{array}{c}\text { Depth of } \\
\text { vulnerability }\end{array}$ & $\begin{array}{c}\text { Severity of } \\
\text { vulnerability }\end{array}$ & Population & $\begin{array}{l}\text { Vulnerable } \\
\text { population }\end{array}$ & Poor population & Depth & Severity \\
\hline Agriculture & 0.418 & 0.106 & 0.303 & 0.127 & 0.052 & $28.6 \%$ & $33.0 \%$ & $41.8 \%$ & $33.1 \%$ & $32.7 \%$ \\
\hline regular employee & 0.428 & 0.143 & 0.359 & 0.154 & 0.074 & $0.7 \%$ & $0.8 \%$ & $1.4 \%$ & $1.0 \%$ & $1.1 \%$ \\
\hline casual and seasonal worker & 0.674 & 0.180 & 0.343 & 0.231 & 0.102 & $0.9 \%$ & $1.6 \%$ & $2.1 \%$ & $1.8 \%$ & $1.9 \%$ \\
\hline employer & 0.237 & 0.029 & 0.273 & 0.065 & 0.022 & $0.5 \%$ & $0.3 \%$ & $0.2 \%$ & $0.3 \%$ & $0.2 \%$ \\
\hline self-employed & 0.412 & 0.104 & 0.300 & 0.124 & 0.051 & $26.6 \%$ & $30.3 \%$ & $38.2 \%$ & $30.1 \%$ & $29.5 \%$ \\
\hline Mining & 0.283 & 0.026 & 0.283 & 0.080 & 0.030 & $0.9 \%$ & $0.7 \%$ & $0.3 \%$ & $0.7 \%$ & $0.6 \%$ \\
\hline regular employee & 0.222 & 0.008 & 0.290 & 0.064 & 0.023 & $0.7 \%$ & $0.4 \%$ & $0.1 \%$ & $0.4 \%$ & $0.3 \%$ \\
\hline casual and seasonal worker & 0.517 & 0.075 & 0.262 & 0.135 & 0.049 & $0.2 \%$ & $0.2 \%$ & $0.2 \%$ & $0.2 \%$ & $0.2 \%$ \\
\hline self-employed & 0.610 & 0.193 & 0.339 & 0.207 & 0.115 & $0.0 \%$ & $0.1 \%$ & $0.1 \%$ & $0.1 \%$ & $0.1 \%$ \\
\hline Manufacturing & 0.357 & 0.049 & 0.304 & 0.109 & 0.045 & $12.1 \%$ & $11.9 \%$ & $8.2 \%$ & $12.0 \%$ & $11.9 \%$ \\
\hline regular employee & 0.372 & 0.052 & 0.309 & 0.115 & 0.048 & $7.8 \%$ & $8.0 \%$ & $5.6 \%$ & $8.2 \%$ & $8.3 \%$ \\
\hline casual and seasonal worker & 0.570 & 0.102 & 0.329 & 0.187 & 0.081 & $0.9 \%$ & $1.4 \%$ & $1.2 \%$ & $1.5 \%$ & $1.5 \%$ \\
\hline employer & 0.173 & 0.009 & 0.231 & 0.040 & 0.014 & $1.8 \%$ & $0.9 \%$ & $0.2 \%$ & $0.7 \%$ & $0.6 \%$ \\
\hline self-employed & 0.380 & 0.052 & 0.297 & 0.113 & 0.044 & $1.6 \%$ & $1.7 \%$ & $1.1 \%$ & $1.7 \%$ & $1.5 \%$ \\
\hline Power, water etc. & 0.183 & 0.025 & 0.208 & 0.038 & 0.013 & $0.4 \%$ & $0.2 \%$ & $0.1 \%$ & $0.2 \%$ & $0.1 \%$ \\
\hline regular employee & 0.193 & 0.026 & 0.208 & 0.040 & 0.014 & $0.4 \%$ & $0.2 \%$ & $0.1 \%$ & $0.2 \%$ & $0.1 \%$ \\
\hline Construction & 0.496 & 0.117 & 0.331 & 0.164 & 0.073 & $7.6 \%$ & $10.4 \%$ & $12.3 \%$ & $11.4 \%$ & $12.2 \%$ \\
\hline regular employee & 0.389 & 0.042 & 0.258 & 0.100 & 0.037 & $1.3 \%$ & $1.4 \%$ & $0.8 \%$ & $1.2 \%$ & $1.1 \%$ \\
\hline casual and seasonal worker & 0.595 & 0.160 & 0.347 & 0.207 & 0.095 & $5.0 \%$ & $8.1 \%$ & $10.9 \%$ & $9.4 \%$ & $10.3 \%$ \\
\hline employer & 0.156 & 0.035 & 0.354 & 0.055 & 0.023 & $0.5 \%$ & $0.2 \%$ & $0.2 \%$ & $0.2 \%$ & $0.2 \%$ \\
\hline self-employed & 0.271 & 0.029 & 0.272 & 0.074 & 0.028 & $0.9 \%$ & $0.6 \%$ & $0.3 \%$ & $0.6 \%$ & $0.5 \%$ \\
\hline Trade & 0.346 & 0.063 & 0.301 & 0.104 & 0.044 & $15.8 \%$ & $15.1 \%$ & $13.6 \%$ & $15.0 \%$ & $15.2 \%$ \\
\hline regular employee & 0.352 & 0.048 & 0.285 & 0.100 & 0.040 & $3.7 \%$ & $3.6 \%$ & $2.5 \%$ & $3.4 \%$ & $3.2 \%$ \\
\hline casual and seasonal worker & 0.566 & 0.148 & 0.359 & 0.203 & 0.097 & $1.1 \%$ & $1.7 \%$ & $2.3 \%$ & $2.1 \%$ & $2.4 \%$ \\
\hline employer & 0.168 & 0.012 & 0.251 & 0.042 & 0.015 & $2.8 \%$ & $1.3 \%$ & $0.5 \%$ & $1.1 \%$ & $0.9 \%$ \\
\hline self-employed & 0.375 & 0.075 & 0.303 & 0.114 & 0.048 & $8.2 \%$ & $8.5 \%$ & $8.4 \%$ & $8.5 \%$ & $8.7 \%$ \\
\hline Transport & 0.370 & 0.062 & 0.296 & 0.110 & 0.045 & $5.8 \%$ & $5.9 \%$ & $5.0 \%$ & $5.8 \%$ & $5.7 \%$ \\
\hline regular employee & 0.336 & 0.040 & 0.276 & 0.093 & 0.034 & $2.4 \%$ & $2.3 \%$ & $1.4 \%$ & $2.1 \%$ & $1.8 \%$ \\
\hline casual and seasonal worker & 0.453 & 0.090 & 0.293 & 0.133 & 0.056 & $0.6 \%$ & $0.8 \%$ & $0.7 \%$ & $0.7 \%$ & $0.7 \%$ \\
\hline employer & 0.206 & 0.000 & 0.193 & 0.040 & 0.012 & $0.3 \%$ & $0.2 \%$ & $0.0 \%$ & $0.1 \%$ & $0.1 \%$ \\
\hline self-employed & 0.403 & 0.084 & 0.320 & 0.129 & 0.056 & $2.5 \%$ & $2.8 \%$ & $2.9 \%$ & $2.9 \%$ & $3.0 \%$ \\
\hline Finance $\&$ banking & 0.189 & 0.000 & 0.206 & 0.039 & 0.010 & $0.6 \%$ & $0.3 \%$ & $0.0 \%$ & $0.2 \%$ & $0.1 \%$ \\
\hline regular employee & 0.188 & 0.000 & 0.207 & 0.039 & 0.010 & $0.6 \%$ & $0.3 \%$ & $0.0 \%$ & $0.2 \%$ & $0.1 \%$ \\
\hline Services & 0.270 & 0.035 & 0.270 & 0.073 & 0.029 & $14.4 \%$ & $10.7 \%$ & $6.9 \%$ & $9.6 \%$ & $9.0 \%$ \\
\hline regular employee & 0.249 & 0.021 & 0.243 & 0.061 & 0.021 & $12.1 \%$ & $8.3 \%$ & $3.5 \%$ & $6.7 \%$ & $5.6 \%$ \\
\hline casual and seasonal worker & 0.572 & 0.151 & 0.381 & 0.218 & 0.108 & $0.6 \%$ & $1.0 \%$ & $1.3 \%$ & $1.2 \%$ & $1.5 \%$ \\
\hline employer & 0.098 & 0.003 & 0.211 & 0.021 & 0.005 & $0.5 \%$ & $0.1 \%$ & $0.0 \%$ & $0.1 \%$ & $0.1 \%$ \\
\hline self-employed & 0.409 & 0.134 & 0.369 & 0.151 & 0.077 & $1.1 \%$ & $1.3 \%$ & $2.1 \%$ & $1.6 \%$ & $1.9 \%$ \\
\hline NOT EMPLOYED & 0.310 & 0.062 & 0.307 & 0.095 & 0.042 & $13.7 \%$ & $11.7 \%$ & $11.7 \%$ & $11.9 \%$ & $12.5 \%$ \\
\hline TOTAL & 0.363 & 0.073 & 0.301 & 0.109 & 0.046 & $100.0 \%$ & $100.0 \%$ & $100.0 \%$ & $100.0 \%$ & $100.0 \%$ \\
\hline
\end{tabular}


Table 17: Individual poverty risk by sector of employment and employment status

\begin{tabular}{|c|c|c|c|c|c|}
\hline \multirow[b]{2}{*}{$\begin{array}{c}\text { Sector and status of employment of a } \\
\text { person }\end{array}$} & \multicolumn{2}{|c|}{ Poverty indicators } & \multicolumn{3}{|c|}{ Structure, percent } \\
\hline & $\begin{array}{l}\text { Incidence of } \\
\text { vulnerability }\end{array}$ & Headcount for poor & Population & $\begin{array}{l}\text { Vulnerable } \\
\text { population }\end{array}$ & Poor population \\
\hline Agriculture & 0.365 & 0.082 & $18.0 \%$ & $18.1 \%$ & $20.3 \%$ \\
\hline regular employee & 0.333 & 0.107 & $0.2 \%$ & $0.2 \%$ & $0.3 \%$ \\
\hline casual and seasonal worker & 0.579 & 0.113 & $0.7 \%$ & $1.2 \%$ & $1.1 \%$ \\
\hline employer & 0.190 & 0.022 & $0.1 \%$ & $0.1 \%$ & $0.0 \%$ \\
\hline self-employed & 0.345 & 0.080 & $6.5 \%$ & $6.1 \%$ & $7.1 \%$ \\
\hline unpaid family worker & 0.364 & 0.081 & $10.5 \%$ & $10.5 \%$ & $11.7 \%$ \\
\hline Mining & 0.260 & 0.033 & $0.2 \%$ & $0.2 \%$ & $0.1 \%$ \\
\hline regular employee & 0.180 & 0.005 & $0.2 \%$ & $0.1 \%$ & $0.0 \%$ \\
\hline casual and seasonal worker & 0.476 & 0.063 & $0.0 \%$ & $0.0 \%$ & $0.0 \%$ \\
\hline employer & 0.132 & 0.000 & $0.0 \%$ & $0.0 \%$ & $0.0 \%$ \\
\hline self-employed & 0.854 & 0.369 & $0.0 \%$ & $0.0 \%$ & $0.1 \%$ \\
\hline unpaid family worker & 0.254 & 0.000 & $0.0 \%$ & $0.0 \%$ & $0.0 \%$ \\
\hline regular employee & 0.336 & 0.045 & $3.5 \%$ & $3.3 \%$ & $2.2 \%$ \\
\hline casual and seasonal worker & 0.462 & 0.089 & $0.5 \%$ & $0.6 \%$ & $0.6 \%$ \\
\hline employer & 0.148 & 0.012 & $0.4 \%$ & $0.2 \%$ & $0.1 \%$ \\
\hline self-employed & 0.398 & 0.063 & $0.6 \%$ & $0.7 \%$ & $0.5 \%$ \\
\hline unpaid family worker & 0.364 & 0.025 & $0.2 \%$ & $0.2 \%$ & $0.1 \%$ \\
\hline Power, water etc. & 0.153 & 0.023 & $0.1 \%$ & $0.0 \%$ & $0.0 \%$ \\
\hline regular employee & 0.161 & 0.024 & $0.1 \%$ & $0.0 \%$ & $0.0 \%$ \\
\hline casual and seasonal worker & 0.000 & 0.000 & $0.0 \%$ & $0.0 \%$ & $0.0 \%$ \\
\hline employer & 0.000 & 0.000 & $0.0 \%$ & $0.0 \%$ & $0.0 \%$ \\
\hline Construction & 0.442 & 0.101 & $1.9 \%$ & $2.4 \%$ & $2.7 \%$ \\
\hline regular employee & 0.350 & 0.045 & $0.4 \%$ & $0.4 \%$ & $0.2 \%$ \\
\hline casual and seasonal worker & 0.537 & 0.137 & $1.2 \%$ & $1.8 \%$ & $2.3 \%$ \\
\hline employer & 0.126 & 0.033 & $0.1 \%$ & $0.0 \%$ & $0.0 \%$ \\
\hline self-employed & 0.210 & 0.024 & $0.2 \%$ & $0.1 \%$ & $0.1 \%$ \\
\hline regular employee & 0.288 & 0.037 & $1.7 \%$ & $1.4 \%$ & $0.9 \%$ \\
\hline casual and seasonal worker & 0.509 & 0.103 & $0.6 \%$ & $0.8 \%$ & $0.8 \%$ \\
\hline employer & 0.141 & 0.009 & $0.7 \%$ & $0.3 \%$ & $0.1 \%$ \\
\hline self-employed & 0.324 & 0.055 & $2.0 \%$ & $1.8 \%$ & $1.5 \%$ \\
\hline unpaid family worker & 0.216 & 0.017 & $0.5 \%$ & $0.3 \%$ & $0.1 \%$ \\
\hline Transport & 0.298 & 0.041 & $1.5 \%$ & $1.3 \%$ & $0.9 \%$ \\
\hline regular employee & 0.261 & 0.026 & $0.7 \%$ & $0.5 \%$ & $0.2 \%$ \\
\hline casual and seasonal worker & 0.447 & 0.064 & $0.2 \%$ & $0.2 \%$ & $0.2 \%$ \\
\hline employer & 0.140 & 0.003 & $0.1 \%$ & $0.0 \%$ & $0.0 \%$ \\
\hline self-employed & 0.321 & 0.057 & $0.6 \%$ & $0.5 \%$ & $0.5 \%$ \\
\hline unpaid family worker & 0.200 & 0.031 & $0.0 \%$ & $0.0 \%$ & $0.0 \%$ \\
\hline Finance and banking & 0.152 & 0.009 & $0.3 \%$ & $0.1 \%$ & $0.0 \%$ \\
\hline regular employee & 0.149 & 0.010 & $0.3 \%$ & $0.1 \%$ & $0.0 \%$ \\
\hline casual and seasonal worker & 0.637 & 0.000 & $0.0 \%$ & $0.0 \%$ & $0.0 \%$ \\
\hline employer & 0.288 & 0.000 & $0.0 \%$ & $0.0 \%$ & $0.0 \%$ \\
\hline self-employed & 0.000 & 0.000 & $0.0 \%$ & $0.0 \%$ & $0.0 \%$ \\
\hline unpaid family worker & 0.000 & 0.000 & $0.0 \%$ & $0.0 \%$ & $0.0 \%$ \\
\hline Other services & 0.209 & 0.027 & $4.9 \%$ & $2.8 \%$ & $1.8 \%$ \\
\hline regular employee & 0.181 & 0.013 & $4.0 \%$ & $2.0 \%$ & $0.7 \%$ \\
\hline casual and seasonal worker & 0.446 & 0.124 & $0.3 \%$ & $0.4 \%$ & $0.5 \%$ \\
\hline employer & 0.105 & 0.002 & $0.1 \%$ & $0.0 \%$ & $0.0 \%$ \\
\hline self-employed & 0.339 & 0.112 & $0.4 \%$ & $0.4 \%$ & $0.6 \%$ \\
\hline unpaid family worker & 0.484 & 0.053 & $0.0 \%$ & $0.0 \%$ & $0.0 \%$ \\
\hline NOT EMPLOYED & 0.383 & 0.079 & $62.2 \%$ & $65.7 \%$ & $67.3 \%$ \\
\hline TOTAL & 0.363 & 0.073 & $100.0 \%$ & $100.0 \%$ & $100.0 \%$ \\
\hline
\end{tabular}


Table 20: Employment status of individuals versus employment of household head

\begin{tabular}{|c|c|c|c|c|c|}
\hline & \multicolumn{2}{|c|}{ Poverty indicators } & \multicolumn{3}{|c|}{ Structure, percent } \\
\hline $\begin{array}{l}\text { Employment status of a person by } \\
\text { employment of household head }\end{array}$ & $\begin{array}{l}\text { Incidence of } \\
\text { vulnerability }\end{array}$ & $\begin{array}{l}\text { Headcount for } \\
\text { poor }\end{array}$ & Population & $\begin{array}{l}\text { Vulnerable } \\
\text { population }\end{array}$ & Poor population \\
\hline H/H head not employed & 0.310 & 0.062 & $13.7 \%$ & $11.7 \%$ & $11.7 \%$ \\
\hline not employed & 0.313 & 0.064 & $11.7 \%$ & $10.1 \%$ & $10.2 \%$ \\
\hline regular employee & 0.253 & 0.035 & $1.1 \%$ & $0.8 \%$ & $0.6 \%$ \\
\hline casual and seasonal worker & 0.475 & 0.089 & $0.3 \%$ & $0.4 \%$ & $0.4 \%$ \\
\hline employer & 0.133 & 0.045 & $0.1 \%$ & $0.0 \%$ & $0.0 \%$ \\
\hline self-employed & 0.284 & 0.070 & $0.4 \%$ & $0.3 \%$ & $0.4 \%$ \\
\hline unpaid family worker & 0.255 & 0.080 & $0.1 \%$ & $0.1 \%$ & $0.2 \%$ \\
\hline H/H head regular employee & 0.309 & 0.037 & $29.8 \%$ & $25.4 \%$ & $15.3 \%$ \\
\hline not employed & 0.333 & 0.042 & $19.8 \%$ & $18.2 \%$ & $11.5 \%$ \\
\hline regular employee & 0.259 & 0.027 & $8.6 \%$ & $6.1 \%$ & $3.2 \%$ \\
\hline casual and seasonal worker & 0.395 & 0.053 & $0.4 \%$ & $0.4 \%$ & $0.3 \%$ \\
\hline employer & 0.006 & 0.000 & $0.0 \%$ & $0.0 \%$ & $0.0 \%$ \\
\hline self-employed & 0.237 & 0.042 & $0.5 \%$ & $0.3 \%$ & $0.3 \%$ \\
\hline unpaid family worker & 0.235 & 0.011 & $0.5 \%$ & $0.3 \%$ & $0.1 \%$ \\
\hline H/H head casual worker & 0.584 & 0.148 & $9.2 \%$ & $14.8 \%$ & $18.8 \%$ \\
\hline not employed & 0.614 & 0.163 & $6.1 \%$ & $10.3 \%$ & $13.7 \%$ \\
\hline regular employee & 0.412 & 0.071 & $0.3 \%$ & $0.4 \%$ & $0.3 \%$ \\
\hline casual and seasonal worker & 0.556 & 0.129 & $2.3 \%$ & $3.6 \%$ & $4.1 \%$ \\
\hline employer & 0.099 & 0.000 & $0.0 \%$ & $0.0 \%$ & $0.0 \%$ \\
\hline self-employed & 0.508 & 0.129 & $0.3 \%$ & $0.4 \%$ & $0.5 \%$ \\
\hline unpaid family worker & 0.361 & 0.079 & $0.2 \%$ & $0.2 \%$ & $0.2 \%$ \\
\hline H/H head employer & 0.169 & 0.013 & $6.4 \%$ & $3.0 \%$ & $1.1 \%$ \\
\hline not employed & 0.174 & 0.015 & $4.2 \%$ & $2.0 \%$ & $0.9 \%$ \\
\hline regular employee & 0.061 & 0.004 & $0.2 \%$ & $0.0 \%$ & $0.0 \%$ \\
\hline casual and seasonal worker & 0.250 & 0.000 & $0.0 \%$ & $0.0 \%$ & $0.0 \%$ \\
\hline employer & 0.146 & 0.010 & $1.5 \%$ & $0.6 \%$ & $0.2 \%$ \\
\hline self-employed & 0.199 & 0.000 & $0.1 \%$ & $0.0 \%$ & $0.0 \%$ \\
\hline unpaid family worker & 0.238 & 0.008 & $0.4 \%$ & $0.3 \%$ & $0.0 \%$ \\
\hline H/H head self-employed & 0.400 & 0.095 & $40.9 \%$ & $45.1 \%$ & $53.2 \%$ \\
\hline not employed & 0.444 & 0.111 & $20.4 \%$ & $25.0 \%$ & $31.1 \%$ \\
\hline regular employee & 0.246 & 0.045 & $0.8 \%$ & $0.6 \%$ & $0.5 \%$ \\
\hline casual and seasonal worker & 0.476 & 0.114 & $0.5 \%$ & $0.7 \%$ & $0.9 \%$ \\
\hline employer & 0.078 & 0.000 & $0.0 \%$ & $0.0 \%$ & $0.0 \%$ \\
\hline self-employed & 0.345 & 0.075 & $9.0 \%$ & $8.5 \%$ & $9.2 \%$ \\
\hline unpaid family worker & 0.370 & 0.083 & $10.0 \%$ & $10.2 \%$ & $11.4 \%$ \\
\hline H/H head unpaid family worker & 0.080 & 0.000 & $0.0 \%$ & $0.0 \%$ & $0.0 \%$ \\
\hline not employed & 0.113 & 0.000 & $0.0 \%$ & $0.0 \%$ & $0.0 \%$ \\
\hline regular employee & 0.000 & 0.000 & $0.0 \%$ & $0.0 \%$ & $0.0 \%$ \\
\hline employer & 0.047 & 0.000 & $0.0 \%$ & $0.0 \%$ & $0.0 \%$ \\
\hline self-employed & 0.070 & 0.000 & $0.0 \%$ & $0.0 \%$ & $0.0 \%$ \\
\hline unpaid family worker & 0.050 & 0.000 & $0.0 \%$ & $0.0 \%$ & $0.0 \%$ \\
\hline TOTAL & 0.363 & 0.073 & $100.0 \%$ & $100.0 \%$ & $100.0 \%$ \\
\hline
\end{tabular}


Table 21: Decomposition of poverty change by household heads sector of employment

\begin{tabular}{|c|c|c|c|c|c|c|}
\hline \multirow[b]{2}{*}{ Sector of employment } & \multirow[b]{2}{*}{$\begin{array}{c}\text { Incidence of } \\
\text { poverty in } \\
1987\end{array}$} & \multirow[b]{2}{*}{$\begin{array}{c}\text { Incidence of } \\
\text { poverty in } \\
1994\end{array}$} & \multirow[b]{2}{*}{$\begin{array}{l}\text { Contribution to } \\
\text { poverty change in the } \\
\text { country, points }\end{array}$} & \multicolumn{3}{|c|}{ of which } \\
\hline & & & & $\begin{array}{l}\text { due to change in } \\
\text { groups poverty } \\
\text { risk }\end{array}$ & $\begin{array}{l}\text { due to } \\
\text { populatio } \\
\text { n shifts }\end{array}$ & $\begin{array}{l}\text { interacti } \\
\text { on term }\end{array}$ \\
\hline Agriculture & $17 \%$ & $11 \%$ & $-2.3 \%$ & $-2.0 \%$ & $-0.6 \%$ & $+0.2 \%$ \\
\hline Mining & $5 \%$ & $3 \%$ & $-0.0 \%$ & $-0.0 \%$ & $+0.0 \%$ & $-0.0 \%$ \\
\hline Manufacturing & $5 \%$ & $5 \%$ & $-0.0 \%$ & $-0.0 \%$ & $-0.0 \%$ & $+0.0 \%$ \\
\hline Power, water, gas & $4 \%$ & $2 \%$ & $-0.0 \%$ & $-0.0 \%$ & $+0.0 \%$ & $-0.0 \%$ \\
\hline Construction & $12 \%$ & $12 \%$ & $+0.2 \%$ & $-0.0 \%$ & $+0.2 \%$ & $-0.0 \%$ \\
\hline Trade & $6 \%$ & $6 \%$ & $+0.1 \%$ & $+0.0 \%$ & $+0.1 \%$ & $+0.0 \%$ \\
\hline Transport & $11 \%$ & $6 \%$ & $-0.3 \%$ & $-0.3 \%$ & $-0.1 \%$ & $+0.0 \%$ \\
\hline Finance and banking & $1 \%$ & $0 \%$ & $-0.0 \%$ & $-0.0 \%$ & $-0.0 \%$ & $+0.0 \%$ \\
\hline Other services & $7 \%$ & $3 \%$ & $-0.7 \%$ & $-0.6 \%$ & $-0.2 \%$ & $+0.1 \%$ \\
\hline All $\mathrm{h} / \mathrm{h}$ with employed heads & $10 \%$ & $7 \%$ & $-3.1 \%$ & $-2.9 \%$ & $-0.5 \%$ & $+0.3 \%$ \\
\hline All households & $10 \%$ & $7 \%$ & $-2.7 \%$ & & & \\
\hline
\end{tabular}

Table 22: Decomposition of poverty change by household heads occupation

\begin{tabular}{|c|c|c|c|c|c|c|}
\hline \multirow[b]{2}{*}{$\begin{array}{l}\text { Occupation of household } \\
\text { heads }\end{array}$} & \multirow[b]{2}{*}{$\begin{array}{c}\text { Incidence of } \\
\text { poverty in } \\
1987\end{array}$} & \multirow[b]{2}{*}{$\begin{array}{c}\text { Incidence of } \\
\text { poverty in } \\
1994\end{array}$} & \multirow[b]{2}{*}{$\begin{array}{l}\text { Contribution to } \\
\text { poverty change in the } \\
\text { country, points }\end{array}$} & \multicolumn{3}{|c|}{ of which } \\
\hline & & & & $\begin{array}{l}\text { due to change } \\
\text { in groups } \\
\text { poverty risk }\end{array}$ & $\begin{array}{c}\text { due to } \\
\text { population } \\
\text { shifts }\end{array}$ & $\begin{array}{l}\text { interaction } \\
\text { term }\end{array}$ \\
\hline professional and technical & $2 \%$ & $1 \%$ & $-0.0 \%$ & $-0.0 \%$ & $-0.0 \%$ & $+0.0 \%$ \\
\hline managers and administrative & $1 \%$ & $2 \%$ & $+0.0 \%$ & $+0.0 \%$ & $-0.0 \%$ & $-0.0 \%$ \\
\hline clerical personnel & $2 \%$ & $2 \%$ & $-0.0 \%$ & $-0.0 \%$ & $-0.0 \%$ & $+0.0 \%$ \\
\hline sales workers & $6 \%$ & $6 \%$ & $-0.1 \%$ & $-0.0 \%$ & $-0.1 \%$ & $+0.0 \%$ \\
\hline service workers & $9 \%$ & $5 \%$ & $-0.3 \%$ & $-0.3 \%$ & $+0.0 \%$ & $-0.0 \%$ \\
\hline agriculture workers & $17 \%$ & $11 \%$ & $-2.2 \%$ & $-1.9 \%$ & $-0.5 \%$ & $+0.2 \%$ \\
\hline $\begin{array}{l}\text { production and related } \\
\text { worker }\end{array}$ & $10 \%$ & $8 \%$ & $-0.5 \%$ & $-0.5 \%$ & $+0.1 \%$ & $-0.0 \%$ \\
\hline armed forces & $0 \%$ & $0 \%$ & $+0.0 \%$ & $+0.0 \%$ & $+0.0 \%$ & $+0.0 \%$ \\
\hline $\mathrm{H} / \mathrm{h}$ without employed heads & $5 \%$ & $6 \%$ & $+0.5 \%$ & $+0.1 \%$ & $+0.3 \%$ & $+0.1 \%$ \\
\hline All households & $10 \%$ & $7 \%$ & $-2.7 \%$ & $-2.7 \%$ & $-0.3 \%$ & $+0.2 \%$ \\
\hline
\end{tabular}




\section{TECHNICAL ANNEX \\ Measuring Economic Vulnerability in Turkey: Methodological Issues}

1. This note summarizes the methodological approaches to analyzing economic vulnerability and measuring poverty in Turkey. The analysis of the 1987 and the 1994 Household Income and Consumption Expenditure Surveys (HICES) was conducted by a joint team from the Household Surveys Department of the State Institute of Statistics (SIS) and the World Bank in May, 1998 February, 1999. The HICES is the most recent nationally representative household survey in Turkey, and as the analysis undertaken by the team has shown, the results of the survey offer a solid base for analyzing living standards and poverty in Turkey.

\section{Introduction: What is poverty?}

2. The definition of poverty dictates how it is measured. In the broadest definition, poverty is the status of a person who falls short of a level of economic welfare deemed to constitute a reasonable minimum, either in some absolute sense or relative to the standards of a specific society. Even this narrow definition has some implications. First, poverty should not be defined just in terms of the intake of calories; the measure of household well-being should be comprehensive. Second, relative and absolute poverty are different concepts, and therefore, measures of poverty obtained using relative and absolute lines are not directly comparable.

3. Before examining the state of poverty in Turkey based on the 1994 household survey data, one has to make several assumptions that reflect one's approach to defining poverty. General concepts of (i) measuring the well-being (using income, expenditure or consumption), (ii) choosing the unit of analysis (individuals or households), and (iii) setting the poverty line (defining the minimum threshold below which the household is deemed to be poor) are discussed below. Finally, (iv) one has to check how robust the conclusions are about poverty to measurement assumptions.

\section{(i) Measuring well-being}

4. Several issues in measuring the living standards determine the result of poverty analysis. The main issues in measuring well-being are: (a) the choice of household welfare indicator (income or consumption); (b) stock and flows problem; and (c) monetary versus non-monetary components of welfare. In this section I first discuss these methodological issues and then present the choices made for analyzing the Turkish data.

\section{(a) Income or consumption?}

5. Typical measures of well-being are income and consumption. For any household, these may differ because families may save or borrow; the poverty status of some households may also be different under the two approaches. The generally preferred indicator of the household living standard is a comprehensive measure of current consumption.

6. There are three reasons why consumption is preferred over income. First, current consumption is often taken to be a better indicator of the current standard of living, since the utility level depends primarily on the actual consumption of goods and services. For that reason, the consumption measure should be as comprehensive as possible. Second, current consumption may also be a best possible approximation to long-term average well-being, because consumption levels tend to fluctuate much less than incomes. Third, experience shows that data on consumption are more accurately collectable. Respondents in agricultural and informal sectors 
may have difficulties in recalling correctly all kinds of income they receive. They may also seek to conceal their income because of taxation and other concerns.

7. On the other hand, there is a prevailing tradition to use income rather than consumption for the analysis of living standards in Turkey. Most of the poverty studies done so far in Turkey have relied on income criteria. In both the 1987 and 1994 surveys, there are relatively small differences between rankings of households by income versus consumption. And for groups which generally have the most problems in recalling income (self-employed and informal sector workers), HICES data shows a close fit between total consumption and income. Thus, one could also use income as a welfare indicator, especially when using an internationally accepted methodology (i.e., the method recommended by OECD) that specifically requires the use of income. That would produce overall incidences of poverty that are comparable to statistics from other countries that use the same approach. However, this approach is not a substitute for using consumption. Based on our argument above, it is fair to say that while the income approach is fine to find out the average risks of poverty, a number of households would be incorrectly classified as poor or non-poor based on their current income.

8. It should be noted that a number of factors make current consumption itself a somewhat noisy welfare indicator. Ideally, one has to use data from as long of a period of the household's life as is possible. Thus, collecting data on consumption for the same household over the whole year may reveal its actual standing better than from collecting data from just one monthly observation. But this information is rarely available form the surveys in most of the countries. Also, the 1987 and 1994 surveys collected information on consumption and income of a household during the survey month. In addition, in 1995 the same households as in 1994 were visited to collect the information on income for the whole past year. Though data from 1995 are from the whole year, the method of their collection (recall during the interview rather than diary as in the case of monthly consumption) makes these data somewhat problematic for welfare measurement. An additional difficulty for using annual data is posed by inflation and is discussed below.

9. Thus, the consumption was used as the primary welfare indicator. We tried to measure as accurately as possible the total monthly current consumption of a household. While use of monthly consumption is still preferred over monthly income, one has to bear in mind the limitations of this indicator. Thus, it is important not to forget that we identify poor families for a particular period when we observe them, and among those we may find those who are permanently poor as well as those suffering from a brief transient shock that has temporarily reduced their welfare. Use of 1987 data for rural areas may be used to analyze the dynamics of living standards within the same household. In rural areas the survey sampled the same households for all 12 months of the survey. Therefore, we have data on continuos monitoring of consumption for the same household throughout the year.

10. Inflation poses many difficulties in accurately measuring welfare of the household. This is a particularly big problem for comparisons between 1987 and 1994 data, and for month-to-month comparisons within 1987 and 1994. For Turkey, the annual inflation rate in 1994 was 106\% (prices roughly doubled throughout the year), and in 1987 the annual inflation was about $40 \%$. Prices rose at a different pace in different regions of the country and very unevenly throughout the year. In principle, in these circumstances one should deflate nominal data recorded in the survey using the appropriate price indices and value the poverty line in the constant prices. Unfortunately, not all the information that is needed to make this adjustment is available in Turkey. The CPI price index is measured monthly by regions of Turkey (differentiating between rural and urban areas for 1994, only urban indices are available for 1987 ). However, price data 
on rural areas are somewhat fragmentary and less reliable than urban prices; the differences in price levels for the goods in CPI basket by regions of the country are available only for 1994. Therefore, while using deflated consumption and income for income distribution and inequality analysis, the use of nominal values was chosen for poverty analysis. To take into account inflation, we have used nominal poverty lines that were valued at monthly local (region plus urban/rural areas) prices.

\section{(b) Problem of stocks and flows}

11. Once the choice of welfare indicator is done, it is important to measure it accurately. Normally, one wish to measure the flow of consumption or income for a household over a certain period of time. Therefore, one has to carefully draw a distinction between flows and stocks. Durables (including housing) that the household owns can be regarded as a part of stocks. On one hand, one has to include the flow of goods and services from the stock that the household owns in its consumption measure; on the other hand, one has to exclude expenditures to replenish stocks or investment in the increase in the stock from monthly current consumption.

12. Data from the 1994 HICES on a balance addresses this issue rather adequately. The consumption from stocks was one of the questions in the dairy part of the questionnaire. The flow of services from an owner, i.e. occupied housing, (the largest item in the total flow of services from stocks to a household ) was asked to be estimated by the respondent as imputed rents. The design of the questionnaire permitted our team to classify in total expenditures the investment components; all investments were excluded from the consumption expenditures of a household. Undoubtedly, the resulting measure of consumption expenditures is quite accurate by international standards. There are, however, some problems and issues that required special attention from the team.

13. In the methodology adopted by the SIS for published results of the 1994 survey, the consumption from stocks was included in total consumption expenditures only for rural areas. The argument was that the pattern of consumption from stocks and their role are different in urban and rural areas. Since it is impossible to find out what part of the current purchases go toward just replenishing or building up stocks, the inclusion of both current purchases and consumption from stocks may lead to double-counting. In fact, if the stocks are constant over time and constitute only a kind of "float" in the household consumption, one should not include the consumption from stocks in the measure of current consumption. That was the argument previously applied to urban households. In contrast, rural households often stock home-produced goods and thus inclusion in the consumption of the monthly flow from this stocks is necessary. The practical argument behind ignoring consumption from stocks was to assure comparability with the 1987 survey that did not included questions on consumption from stocks for urban households.

14. The analysis conducted by the team showed that while consumption from stocks in urban areas is indeed a much smaller share of total consumption, it follows absolutely the same time pattern as consumption from stocks in rural areas. The stocks are not constant throughout the year in urban households. Solely based on that finding, the exclusion of consumption from stocks for urban households is incorrect and leads to a (slight) underestimation of their consumption. It creates problems because this bias is different for households in cities with different sizes and different regions (small cities located in agricultural regions have very similar consumption patterns to rural areas). Thus, the decision was taken to include consumption from stocks into the total household consumption. 
15. Data from 1987 survey are more problematic in the way how consumption from stocks was measured. Data on the total value of stocks were collected only in rural areas and only at the beginning and the end of the year. Therefore, there is no information on the flow of consumption from stocks. The team has imputed the value based on the stock from the beginning of the year, and the assumption that it is used up completely in 12 months. But this estimate is not directly comparable to 1994 monthly data where the actual flow of consumption was measured. Therefore, the consumption variable from the 1987 survey underestimates the actual consumption of households and thus direct comparisons of consumption are not correct.

16. The source of another concern is imputing the flow of services from durable goods. Omitting the flow of services from owned durables may introduce a measurement error in the living standard indicator. But to do this adjustment accurately one has to have detailed information on 1) age and trademark of durables owned by the household; and 2) information on their monthly prices and/or expected years of service. This information was either missing or difficult to assemble in the case of Turkey. Therefore, the adjustment to the consumption with the inclusion of flow of services from durables was not possible to do.

17. When it is possible to include flow of services from durables in the consumption measure, normally one would wish to exclude the current purchases of these items. In fact, purchase of a durable good in a particular month is often a result of previously accumulated savings and thus may distort the measurement of current consumption. The exclusion of expenditures on durables in the case of Turkey has proven to be a very difficult task. Durables do not constitute a special standard sub-group in the classification of total expenditures, but have to be identified based on the 10-digit code in many sub-groups. In one particular case - passenger vehicles - such an identification was nevertheless carried out, and the corresponding expenditures excluded from household total expenditures ( 52 cases or $0.2 \%$ of the households in the survey). This adjustment was deemed important for analyzing inequality, since households that happened to spend money on cars had the largest values for total household expenditures in the survey only for that reason. No other item among durables had produced such a strong effect. Therefore the exclusion of spending on cars from current monthly consumption expenditures has reduced noticeably the measured dispersion in consumption. Inequality in consumption measured by the Gini coefficient has been reduced by $5 \%$. This adjustment does not affect poverty measures at all: all households that made car purchases were still on the top of the distribution even after this adjustment.

18. Though the final measure of consumption expenditures is better designed to capture the differences in welfare of households than consumption expenditure used before, it should not be forgotten that the new measure represents a compromise between the feasibility and full accuracy in its treatment of stocks and flows. As analysis of data from other countries has shown (see Hentschel and Lanjouw), the non-adjustment of consumption indicator for durables produces only a slight bias in the ranking of households and overall measurement of living standards. Therefore, the constructed aggregate of current consumption is adequate for poverty analysis.

\section{(c) Monetary and non-monetary components}

19. Finally, one has to estimate in-kind components of welfare. Note that all goods received in-kind and consumed enter on both the income and expenditure sides of the flow of funds for a household. Therefore, regardless of what indicator of welfare is chosen, one has to care about measuring in-kind consumption carefully. 
20. There are three sources of problems while measuring consumption in kind: 1) in-kind earnings and transfers in-kind; 2) own agricultural produce consumption; and 3) goods and services received for free or at a subsidized price. As I am going to show below that the 1987 and 1994 surveys in Turkey adequately addressed the first two, it proves to be difficult to do anything with (3).

21. Individuals in the survey were asked to specify the estimates of values of benefits received in-kind from employer (output produced, food, transportation, health care), or aid received in kind from the Government, organizations or individuals (food, non-food goods, fuel, medicaments). The respondents' valuations of these benefits in-kind are, of course, subject to criticism; but for most of the goods and services there are parallel market prices, and probably most of the responses are close to actual market values.

22. To measure in-kind consumption of home produced goods and of using common property resources (fish caught in the river, or fuel collected in the forest) the questionnaire asks for each good consumed whether it was produced at home or bought. Respondents are also asked to evaluate the market value for consumption of home produced food, clothes etc.

23. In-kind benefits received from society (subsidized food, publicly provided education, health care etc.) are a source of greater concern. Normally here we observe a combination of some partial payment (often out-of pocket) and in-kind aid. The household survey includes questions on the value of goods in-kind received for free from State, NGOs, employers and individuals. But subsidized services or goods are difficult to trace, and in this case it was impossible to impute the monetary value of these goods and services, because there was no specific details or information on the use of these by the household.

\section{(d) Evaluation of the consumption aggregate}

24. The data collected in both 1987 and 1994 seem to address adequately most of the problems in measuring well-being. As a result, the current consumption indicator for measuring living standards and poverty based on Turkish household data offers quite a reliable base. The consumption aggregate includes:

- monetary non-business and non-investment expenditures (1987 and 1994)

- gifts, earnings and transfers in-kind (1987 and 1994)

- consumption from stocks (1994, but not in 1987)

- consumption from own production (1987 and 1994)

- imputed rents from owner-occupied housing (1987 and 1994).

25. There are three sources of bias in this indicator for Turkey. First, the expenditures on all durables (except cars) are included in current monetary consumption expenditures of households. This tends to overestimate the current consumption of some households. Second, the consumption aggregate does not include imputed flow of services from all durable goods that household owns. As a result, consumption for many households may be underestimated. However, if the poverty line is constructed on the basis of survey data, the resulting poverty picture will not be distorted by this problem. Third, and most importantly, the imputation of market value of subsidized goods and services was impossible. This could be a source of a serious trouble in adequately measuring poverty and inequalities in well-being, when the access and use of such goods and services are not universal. 
26. The existence of biases in the indicator of consumption requires taking it into account while constructing the poverty line. The first and second biases could be ignored in a framework of vulnerability analysis on the assumption that poor households are not buying too much of durable goods anyway. Simply in setting the non-food share in the poverty basket on the level of observed rather than normative values, is enough to correct for the second bias. The third bias is potentially more distortionary. To partly remedy the situation, whenever feasible, one has to include explicitly some subsidized goods in the poverty basket, and price information on these goods should be applied to set the line according to the availability of these goods for the poor groups of the population. We have done so by including the municipal bread in the minimum food basket of urban population. We hope, based on macroeconomic data, that the overall level of subsidies is not too high to seriously damage the quality of the living standards analysis.

\section{(ii) Unit of analysis}

27. The analysis in the profile focuses on poverty among Turkish households; if a household is deemed to be poor, all its members are counted as poor. The implicit assumption here is that all individual members of a household benefit equally (or in constant proportion, depending on their age and gender, called equivalence scale), from the household's expenditure or income.

28. Consumption data from household surveys are usually collected at the level of the household rather than the individual. This means that in attributing to individuals within the household their share of household resources, an adjustment based on some allocation rule must be imposed. Though there exists little guidance for choosing among the wide range of possible scales, it is important to examine the sensitivity of poverty comparisons to the particular allocation rule chosen.

29. In many developing countries, the literature on poverty has tended to use per capita measures. The minimum food standard used to set the poverty line dictated the use of a caloric scale to count the number of equivalent adults in the household. In a general, from such a conversion follows the simple formula,

$$
E=\sum_{j} \alpha_{j} n_{j} ;
$$

where $\mathrm{E}$ is the number of equivalent adults, the individuals in the household are divided into $\mathrm{J}$ different demographic groups each having its conversion factor to equivalent adult equal to $\alpha_{\mathrm{j}}$, and number of members in each group is $n_{j}$. The coefficients $\alpha$ and corresponding demographic groups were:

$\begin{array}{lc}\text { Small Children (under 5) } & 0.64 \\ \text { Children (5-11) } & 1.00 \\ \text { Male adolescent (12-17) } & 1.00 \\ \text { Female adolescent (12-17) } & 0.84 \\ \text { Prime working age male (18-39) } & 1.00 \\ \text { Prime working age female (18-39) } & 0.84 \\ \text { Retirement age male (40+) } & 0.88 \\ \text { Retirement age female (40+) } & 0.76\end{array}$

30. These coefficients are based on the minimum caloric needs for different demographic groups, as presented, for example, in FAO(1994). The highest number of minimum calories relative to the needs of working age male are used for each group (for example, children in the age group 0-5 years have different minimum caloric needs, the maximum is for 5 years old, and this was taken as value for the whole group). This may lead to some "flattening" of the equivalence 
scale towards per capita measures. To correct for this, an additional adjustment for economies of scale was used (see below). As an alternative approach, the OECD equivalence scale with very strong adjustment was used for departing away from per capita measures.

31. In addition, it is possible that there exist economies of scale in consumption, such that the per capita cost of reaching a certain welfare level is lower in large households than in small ones. For example, cost of heating might depend on dwelling characteristics, irrespective of whether the residing family is large or small. But the per capita cost of heating is, of course, lower for the large family. To measure such economies of scale, one uses a special parameter $\theta$. It is assumed that the effective number of household members that share a certain welfare should be adjusted using this economies of scale parameter, that is welfare per member (w) in a household with $\mathrm{n}$ members equals total household welfare (W) divided by $n \theta$

$$
w=\frac{W}{n^{\theta}}
$$

32. Theta equal to .5 , for example, implies, that to achieve the same level of welfare as a single-person household spending one unit, a family of three will have to spend only 1.73 units (30.5), i.e. 0.57 per each member instead of 1 . Such magnitude for economies of scale is the one that is widely accepted by statistical agencies in many OECD countries.

33. The use of equivalent adults instead of the number of individuals already implies some economies of scale. As we have seen, all demographic groups have $\alpha$ less or equal to 1 . In the case of Turkey, the demographic equivalence scale used implied the parameter of $\theta$ equal to 0.913 - a rather small adjustment.

34. In Turkey, where joint multigenerational families are not rare (in fact, $63 \%$ of the population live in such families), taking into account the economies of scale is crucial; so far, there has been no attempt to estimate it empirically on Turkish data.

35. The framework adopted by researchers who try to estimate this effect is taken from the Lanjouw and Ravallion article of 1995 and based on the Engel curve. To summarize it in simplest form, the share of spending devoted to food is taken as an inverse wealth indicator. In this model the food share is regressed on the log of expenditures per person and a set of demographic variables; by adding a parameter for effects of household size independently of these variables, one obtains the basic from that is tested on data by using, for example, the minimum least squares method,

$$
\mathrm{w}_{\mathrm{i}}=\mathrm{a}+\mathrm{b} \ln \left(\mathrm{x}_{\mathrm{i}} / \mathrm{n}_{\mathrm{i}}{ }^{\theta}\right)+\sum_{j}^{J-1} \mathrm{c}_{\mathrm{j}} \mathrm{e}_{\mathrm{ji}}+\text { regional effects+residual, }
$$

where $\mathrm{w}_{\mathrm{i}}$ denotes the budget share devoted to food by household $\mathrm{i}$, and $\mathrm{e}_{\mathrm{ij}}$ is the proportion of persons in household $\mathrm{i}$ who belong to category $\mathrm{J}$. In that specification the compositional effect $\mathrm{c}_{\mathrm{j}}$ (equivalence scale per se) is estimated alongside the size elasticity $\theta$ (or economies of scale effect), by isolating the pure compositional effect from the effect of household size $n$.

36. Applying this to Turkey and taking into account the survey stratification and clustering, we obtain the following regression results (standard errors are corrected errors using the Huber/White/sandwich correction): 


gidapay
gidrerr

37. The first two variables are log of household expenditures and log of the total number of household members; the estimated values of $\theta$ are obtained by dividing the coefficient of the second term by the coefficient for the first term. In this case the value lies in the $95 \%$ confidence interval between 0.746 and 0.873 and is different from one. Therefore, per capita measures are inappropriate for measuring welfare in Turkey. The demographic coefficients (terms3-8) are together significant and show that the use of equivalence scale is appropriate. There are 58 dummies (adsorbed in output) for provinces in the survey and a dummy for rural versus urban areas.

38. It was decided to use an upper bound estimate for possible economies of scale, thus lower values of $\theta$; the number of equivalent adults in the household was raised to the power of 0.75 (the regression with survey weights yielded 0.75 as the middle of confidence interval). The example below shows the effective household size for measuring the welfare of household members for different types of Turkish families.

\begin{tabular}{|l|c|c|c|}
\hline & $\begin{array}{c}\text { Number of } \\
\text { members }\end{array}$ & $\begin{array}{c}\text { Number of } \\
\text { equivalent } \\
\text { adults }\end{array}$ & $\begin{array}{c}\text { Effective size } \\
\text { with economies of } \\
\text { scale adjustment }\end{array}$ \\
\hline Single male living alone & 1 & 1 & 1 \\
\hline $\begin{array}{l}\text { Married couple of working age with 2 small } \\
\text { children }\end{array}$ & 4 & 3.12 & 2.35 \\
\hline $\begin{array}{l}\text { Married couple with 2 small children and 2 elderly } \\
\text { parents }\end{array}$ & 6 & 4.76 & 3.22 \\
\hline $\begin{array}{l}\text { Married couple+ 4 (2small, 2 school age) children } \\
+2 \text { elderly parents }\end{array}$ & 8 & 6.76 & 4.19 \\
\hline
\end{tabular}

39. There is a long simmering debate about the validity of "quantitative" analyses of poverty because anthropological, sociological and participatory poverty studies tend to find that large households are much better protected against poverty than small, nuclear households, while the opposite conclusion is reached from quantitative studies which apply a per capita measure of welfare. Setting economies of scale is a very approximate science. It relies heavily on normative assumptions that are accepted in a society. Within the tradition that exists in Turkey, there is a strong preference for using per capita measures. Among only a few acceptable alternatives are OECD equivalence scales, where the number of equivalent adults is simply n0.5. Based on the results of the test described above, such an adjustment can be regarded as a bit extreme, but gives a good robustness check for the main results obtained using the main relatively moderate approach. 
40. There are some problems with this estimate. Strong identifying assumptions are needed to justify the Engel curve method. However, most of the researchers are quite convinced, mainly because of the findings from the subjective poverty literature in Western Europe and now recently in A. Deaton's and M. Ravallion's work, that the assumption of no economies of scale is more extreme than an assumption of some economies of scale.

\section{(iii) Definition of the poverty line}

41. There are two approaches to set the poverty line. One using an absolute poverty line, and the other using a relative poverty line. Both are valid methods, and they give different results. Note that these two approaches are based on different definitions of poverty, so we should expect numbers of poor and even their characteristics to differ considerably between these two approaches. In this section I, first describe the approaches chosen to set the minimum food basket and the absolute poverty line. The relative line was chosen according to one of the variants of OECD methodology described in the second section. Finally both relative and absolute lines are evaluated in light of international experience.

\section{(a) Setting the absolute line}

42. Setting an absolute line is not an easy task. How does one derive a cost of normative nutritional requirement and make allowances for non- food consumption? There are two ways to do this.

43. One popular method to set an absolute line is to find the consumption expenditure at which a person is expected to attain the food energy requirement. This can be readily estimated from a graph (plotting actual calories intake for households against actual current expenditures) or regression. You are just going to need the caloric values for all food items consumed by households. Price data are not needed and the method automatically includes allowances for nonfood consumption.

44. However, while fine for a single national poverty line, this method can yield inconsistent poverty comparisons across sub-groups and especially across regions; the problem is that the relationship between energy intake and expenditures is not going to be the same across subgroups, but will shift according to affluence, tastes, activity levels and publicly provided goods. For instance, poverty lines derived by this method tend to be higher in richer regions, where households tend to buy more "expensive" calories and may cause a complete rank reversal and inconsistencies in the poverty profile (i.e., when a person migrates from poor to richer region, this could lead to an increase in the aggregate poverty measure even though this person is better off in terms of real consumption).

45. An alternative method is to use a normative food consumption bundle valued directly in the local prices. The food bundle is anchored to the nutritional requirement and consistent with tastes of the poor. Such a bundle exists in Turkey which was developed by the Hacateppe University and is widely used by researchers who attempt to measure poverty in Turkey. Unfortunately, quantities of food in the basket are defined in broad product groups (vegetables, fruits etc.). To make a meaningful poverty line, one tries to define products very narrowly (down to specific items). Otherwise, in the use of average "group" prices more expensive items consumed predominantly by the rich could lead to an overestimate of the minimum food basket cost. 
46. To solve this problem, we have selected 19 most important food items consumed predominantly also by the poor. To account for subsidized goods, one such item, municipal bread, was explicitly included in the minimum food basket for urban areas. The table below gives the quantities for items per equivalent adult per day and nutrient value for main nutrients in percentages recommended by the USA FDA for working age males.

\begin{tabular}{|c|c|c|c|}
\hline \# & Produce & \begin{tabular}{|c||} 
Grams purchased \\
(per day, per \\
equivalent adult)
\end{tabular} & $\begin{array}{l}\text { Percent consumed } \\
\text { (taking into } \\
\text { account waste) }\end{array}$ \\
\hline 1 & Rice (common variety) & 60 & $100 \%$ \\
\hline 2 & Beans & 50 & $95 \%$ \\
\hline 3 & White flour, normal grade, in packets & 60 & $95 \%$ \\
\hline 4 & White bread (normal grade)* & 350 & $100 \%$ \\
\hline 5 & Mutton & 120 & $75 \%$ \\
\hline 6 & Yogurt & 350 & $95 \%$ \\
\hline 7 & Feta cheese & 30 & $100 \%$ \\
\hline 8 & Eggs & 50 & $100 \%$ \\
\hline 9 & Oil & 30 & $100 \%$ \\
\hline 10 & Apples & 100 & $80 \%$ \\
\hline 11 & Watermelons & 200 & $60 \%$ \\
\hline 12 & Tomatoes & 150 & $95 \%$ \\
\hline 13 & Carrots & 100 & $55 \%$ \\
\hline 14 & Jam & 30 & $100 \%$ \\
\hline 15 & Black olives & 20 & $100 \%$ \\
\hline 16 & Onions & 50 & $80 \%$ \\
\hline 17 & Potatoes & 150 & $70 \%$ \\
\hline 18 & Sugar & 60 & $100 \%$ \\
\hline & KCAL & & 2450 \\
\hline & Protein (\% RDA) & & $137 \%$ \\
\hline & Vitamin A (\% RDA) & & $135 \%$ \\
\hline & Vitamin C (\% RDA) & & $108 \%$ \\
\hline & Iron (\%RDA) & & $193 \%$ \\
\hline & Calcium (\%RDA) & & $137 \%$ \\
\hline & Total fat (g) & & 81 \\
\hline
\end{tabular}

* In urban areas - $200 \mathrm{~g}$ of municipal and $150 \mathrm{~g}$ common

47. The nutrient analysis shows that the diet proposed is rather rich and exceeds the minimum requirements for many major nutrients. Thus, the food line that is used for Turkey is relatively "generous".

48. Computing average purchased prices from the survey data for these items by month of the survey (12), by region (7) and urban/rural areas within region, we have obtained a set of 168 locality and time-specific food lines. If the total household consumption divided by its effective size (i.e. taking into account the equivalence scale and economies of scale in consumption) is less than the cost of the minimum food basket, one classifies the household as poor. But the minimum food basket is not a fully comprehensive measure of living standards. One has to take into account non-food basic needs. The full line that includes minimum food basket costs and basic non-food spending is called "vulnerability line".

49. Setting this non-food component is difficult. Taking the average food share is inappropriate: according to Engel's law, poorer households have higher food share. Therefore taking an average would seriously overestimate the actual minimum living standard norm. It is 
widely accepted that for setting the non-food component of the poverty line one takes the expected non-food spending of those who are just capable of reaching the cost of the minimum food basket. One assumes that these households really choose necessities in their non-food spending.

50. To obtain an estimate that is consistent with the model of demand developed by Deaton and Muellbauer, one has to estimate a regression (with appropriate correction for standard errors for sample design) that would give an estimate of the food share in the poverty basket in the following form:

Foods share $\mathrm{w}_{\mathrm{ij}}=\mathrm{a}_{\mathrm{j}}+\mathrm{b}_{\mathrm{j}} \log \left(\right.$ Current consumption $\mathrm{i} /$ Food line $\left.\mathrm{j}_{\mathrm{j}}\right)+\mathrm{u}_{\mathrm{ij}}$,

where $\mathrm{i}$-th household is located in $\mathrm{j}$-th region; $\mathrm{u}$ is an error term; estimated coefficients for $a_{j}$ are specific for each region and would give the share food expenditures for those who could have just achieved a nutritional minimum. With regional dummies this regression gives a satisfactory fit, with a statistically significant estimate of food share for urban areas (Marmara region) at .46816 (see regression output below). There are some differences between regions, with food share in rural areas higher by 10 percentage points. See in detail on the assumptions for this estimation Ravallion (1994).

\begin{tabular}{|c|c|c|c|c|c|c|c|}
\hline \multicolumn{8}{|c|}{ of obs } \\
\hline Strata: & b1t03s01 & & & Num & of strata & $=$ & 4 \\
\hline PSU: & faktor 1 & & & Num & of PSUs & $=$ & 1202 \\
\hline & & & & Pop & tion size & $=$ & $1.601 e+08$ \\
\hline & & & & Fi & 1191) & $=$ & 381.35 \\
\hline & & & & Pro & $\mathrm{F}$ & $=$ & 0.0000 \\
\hline & & & & $\mathrm{R}-\mathrm{s}$ & red & $=$ & 0.4271 \\
\hline gidapay & Coef. & Std. Err. & t & $P>|t|$ & [95\% Con & f. & Interval] \\
\hline Intoptuk & -.1254053 & .0027044 & -46.370 & 0.000 & -.1307113 & & -.1200993 \\
\hline Ib1t01_2 & .0192393 & .0085777 & 2.243 & 0.025 & .0024103 & & .0360682 \\
\hline Ib1t01_3 & .031372 & .0078246 & 4.009 & 0.000 & .0160205 & & .0467235 \\
\hline Ib1t01_4 & .0221004 & .0088303 & 2.503 & 0.012 & .0047758 & & .039425 \\
\hline Ib1t01_5 & .064271 & .013832 & 4.647 & 0.000 & .0371334 & & .0914087 \\
\hline Ib1t01_6 & .0216827 & .0110077 & 1.970 & 0.049 & .0000862 & & .0432793 \\
\hline Ib1t01_7 & .0690872 & .0096545 & 7.156 & 0.000 & .0501456 & & .0880288 \\
\hline kir & .1046355 & .0064488 & 16.226 & 0.000 & .0919834 & & .1172876 \\
\hline _cons & .4681649 & .0053492 & 87.520 & 0.000 & .45767 & & .4786598 \\
\hline
\end{tabular}

51. Thus the full poverty line or "vulnerability line" is approximately double the food line for urban areas and 1.75 of the cost of minimum food basket in rural areas. This gives us a relatively high poverty line by international standards: both the food basket and non-food allowances are much higher than in an average developing country. For that reason, we have decided to call this line a "vulnerability", rather than a "poverty" line, and consider households below this line as economically vulnerable (see in more detail in section c below).

\section{(b) Setting the relative line}

52. According to the variant of the OECD methodology used to set the relative line, it equals $1 / 2(50 \%)$ of the monthly median expenditure per equivalent adult defined according to OECD equivalence scale (for any given month of the survey). There are subsequently 12 poverty lines one for each month. Households with nominal monthly income divided by their effective size less than the corresponding relative line are called relatively poor, or poor according to OECD definition. 
53. We can summarize the approaches used to measure poverty in Turkey in the following table:

\begin{tabular}{|l|l|l|l|}
\hline & $\begin{array}{l}\text { Welfare } \\
\text { aggregate }\end{array}$ & $\begin{array}{l}\text { Welfare measure per } \\
\text { household member }\end{array}$ & Poverty line \\
\hline Food poverty (poor) & $\begin{array}{l}\text { Current } \\
\text { consumption }\end{array}$ & $\begin{array}{l}\text { Household } \\
\text { consumption/ }(E)^{75}\end{array}$ & $\begin{array}{l}\text { Local cost of minimum food } \\
\text { basket }\end{array}$ \\
\hline $\begin{array}{l}\text { Economic } \\
\text { vulnerability }\end{array}$ & $\begin{array}{l}\text { Current } \\
\text { consumption }\end{array}$ & $\begin{array}{l}\text { Household } \\
\text { consumption/ }(E)^{75}\end{array}$ & $\begin{array}{l}\text { Local poverty line=local cost } \\
\text { of minimum food basket+ } \\
\text { local non-food share }\end{array}$ \\
\hline Relative poverty & Total income & $\begin{array}{l}\text { Household } \\
\text { income/ }(n)^{.5}\end{array}$ & $\begin{array}{l}\text { National: one half of the } \\
\text { median income per equivalent } \\
\text { adult in the corresponding } \\
\text { month }\end{array}$ \\
\hline
\end{tabular}

\section{(c) Approaches used for Turkey in an international perspective}

54. The food line is constructed according to best practice, using the survey-generated prices. The composition of the basket may be a bit too generous. This is shown in the following table that makes international comparisons of the minimum food basket with countries at lower levels of income (India and Indonesia), comparable levels of income (Russia and Equador) and higher levels of income (USA).

55. Thus the measures of poverty and vulnerability are going to be overestimated once we compare them to developing countries where lower nutritional lines, and most importantly baskets containing less expensive foods (like animal products) are set. The full absolute poverty line or vulnerability line is derived based on best international practice, and is subject only to the bias mentioned for the food line; large allowances for non-food reflects relatively high standards of living of Turkish households compared to developing countries. 
Food allowances and calories intake in the minimum food baskets:

some international comparisons

\begin{tabular}{|c|c|c|c|c|c|c|}
\hline & $\begin{array}{l}\text { USA } \\
\text { (USDA } \\
\text { Thrifty } \\
\text { food plan } \\
\text { for 20-50 } \\
\text { y.o. male) }\end{array}$ & $\begin{array}{l}\text { Turkev } \\
\text { (Hacateppe } \\
\text { University for } \\
\text { equivalent } \\
\text { adult) }\end{array}$ & $\begin{array}{l}\frac{\text { Russia }}{\text { (Min. of }} \\
\text { Labor min. } \\
\text { food basket } \\
\text { for working } \\
\text { male) }\end{array}$ & $\begin{array}{l}\text { Ecuador } \\
\text { (World bank, } \\
\text { per capita) }\end{array}$ & $\begin{array}{l}\frac{\text { India }}{(N S S,} \\
\text { per } \\
\text { capita) }\end{array}$ & $\begin{array}{l}\frac{\text { Indonesi }}{\text { a }(\text { World }} \\
\text { bank, per } \\
\text { capita) }\end{array}$ \\
\hline KCal/Day & 2700 & 2450 & 2700 & 2237 & 2100 & 2150 \\
\hline Bread and grains & 335 & 510 & 485 & 279 & 420 & 533 \\
\hline Potatoes & 96 & 150 & 438 & 168 & 120 & \\
\hline Fruits & 145 & 300 & 40 & 60 & 30 & \\
\hline Onions & 60 & 50 & 96 & 0 & 43 & \\
\hline Meats & 210 & 120 & 88 & 35 & 0 & \\
\hline Oil and butter & 48 & 30 & 22 & 38 & 15 & \\
\hline Cheese & 8 & 30 & 7 & 10 & 0 & \\
\hline Eggs (no) & 0.58 & 1.00 & 0.49 & 0.00 & 0.2 & \\
\hline Milk and yogurt & 314 & 350 & 350 & 100 & 70 & \\
\hline
\end{tabular}

Note: Turkey - Guzin Erdogan (1996); Russia - Goskomstat; India - India: achievements... (1997); Indonesia Ravallion (); USA: USDA family food plans, 1983, thrifty plan, table 1; Ecuador - Hentschel and Lanjouw().

\section{(iv) how robust are findings of the poverty profile?}

56. Given a variety of reasons, the poverty numbers are always estimated with some degree of arbitrariness. As we have mentioned, each country decides on its minimum living standard and these may vary substantially, reflecting the level of economic development, cultural and political factors.

57. The table below lists all of the approaches that were used to measure poverty and economic vulnerability in Turkey. It shows that there are large variations in the total number of people who are counted as poor or economically vulnerable between different methodologies, thus, focusing on a single line or single approach is always amenable to criticism. Therefore, one has to check how robust the findings are about poverty profile and its determinants to the methodological assumptions. 
Sensitivity of poverty headcounts for Turkey with respect to various methodological assumptions in measuring well-being

\begin{tabular}{|c|c|c|}
\hline Approach & Variations in the methodology & $\begin{array}{l}\text { Percent of the population } \\
\text { below the line }\end{array}$ \\
\hline \multicolumn{3}{|c|}{ Consumption based approaches } \\
\hline $\begin{array}{l}\text { Basic approach (to } \\
\text { identify the } \\
\text { economically } \\
\text { vulnerable) } \\
10 \% \text { lower line } \\
10 \% \text { higher line }\end{array}$ & $\begin{array}{l}\text { Local cost of basic needs(vulnerability) basket versus } \\
\text { consumption per equivalent adult with moderate economies } \\
\text { of scale }\end{array}$ & $\begin{array}{l}30.3 \% \\
42.5 \%\end{array}$ \\
\hline Poverty & $\begin{array}{l}\text { Local cost of minimum food basket versus consumption per } \\
\text { equivalent adult with moderate economies of scale }\end{array}$ & $7.3 \%$ \\
\hline $\begin{array}{l}10 \% \text { lower line } \\
10 \% \text { higher line }\end{array}$ & & $\begin{array}{l}5.2 \% \\
9.8 \%\end{array}$ \\
\hline $\begin{array}{l}\text { Absolute poverty by } \\
\text { international } \\
\text { standards }\end{array}$ & $\begin{array}{l}\text { One - Dollar - A -Day per capita at the purchasing power parity } \\
\text { in } 1985 \text { prices }\end{array}$ & $2.5 \%$ \\
\hline $\begin{array}{l}\text { Per capita measures } \\
\text { of vulnerability }\end{array}$ & $\begin{array}{l}\text { Local cost of vulnerability basket versus consumption per } \\
\text { capita, no economies of scale }\end{array}$ & $61.6 \%$ \\
\hline $\begin{array}{l}\text { OECD equivalence } \\
\text { scale measure of } \\
\text { vulnerability }\end{array}$ & $\begin{array}{l}\text { Local cost of vulnerability basket versus consumption per } \\
\text { equivalent adult, large economies of scale }(0.5)\end{array}$ & $14.0 \%$ \\
\hline $\begin{array}{l}\text { Constant prices } \\
\text { measure of } \\
\text { vulnerability }\end{array}$ & $\begin{array}{c}\text { Cost of vulnerability basket in average } 1994 \text { prices versus } \\
\text { deflated consumption (CPI index, 1994=100) per equivalent } \\
\text { adult, moderate economies of scale }\end{array}$ & $33.9 \%$ \\
\hline \multicolumn{3}{|c|}{ Income based approaches } \\
\hline $\begin{array}{l}\text { Basic approach, } 1994 \\
\text { monthly data }\end{array}$ & $\begin{array}{l}\text { Local cost of basic needs(vulnerability) basket versus current } \\
\text { monthly income per equivalent adult with moderate economies } \\
\text { of scale }\end{array}$ & $29.6 \%$ \\
\hline $\begin{array}{l}\text { Basic approach, } 1994 \\
\text { annual data* }\end{array}$ & $\begin{array}{l}\text { Local average annual cost of basic needs(vulnerability) basket } \\
\text { versus annual income per equivalent adult with moderate } \\
\text { economies of scale }\end{array}$ & $28.4 \%$ \\
\hline $\begin{array}{c}\text { OECD } \\
\text { methodology, } 1994 \\
\text { monthly data } \\
\text { (relative poverty) }\end{array}$ & $\begin{array}{l}\text { One half of the current monthly national median total } \\
\text { income per equivalent adult, large economies of scale }(0.5)\end{array}$ & $15.7 \%$ \\
\hline $\begin{array}{l}\text { OECD methodology, } \\
1994 \text { annual data } \\
\text { (relative poverty) } \\
\end{array}$ & $\begin{array}{l}\text { One half of the annual national median total income per } \\
\text { equivalent adult, large economies of scale }(0.5)\end{array}$ & $14.7 \%$ \\
\hline
\end{tabular}

58. While the overall incidence changes quite dramatically between approaches, most of the economic characteristics are very robust to changes in the measurement assumptions. 
59. The unusual finding of roughly equal risks of poverty between rural and urban areas is explained by much lower price levels in rural areas. Therefore the relative ranking of urban and rural areas by poverty risk is sensitive to measurement assumptions, as revealed by the following graph.

60. The graph shows that whenever we apply the same poverty line for urban and rural poverty, the rural poverty is always worse than urban. The gap is particularly substantial when we take total annual incomes.

Sensitivity of poverty risk by urban/rural areas to methodology of poverty measurement

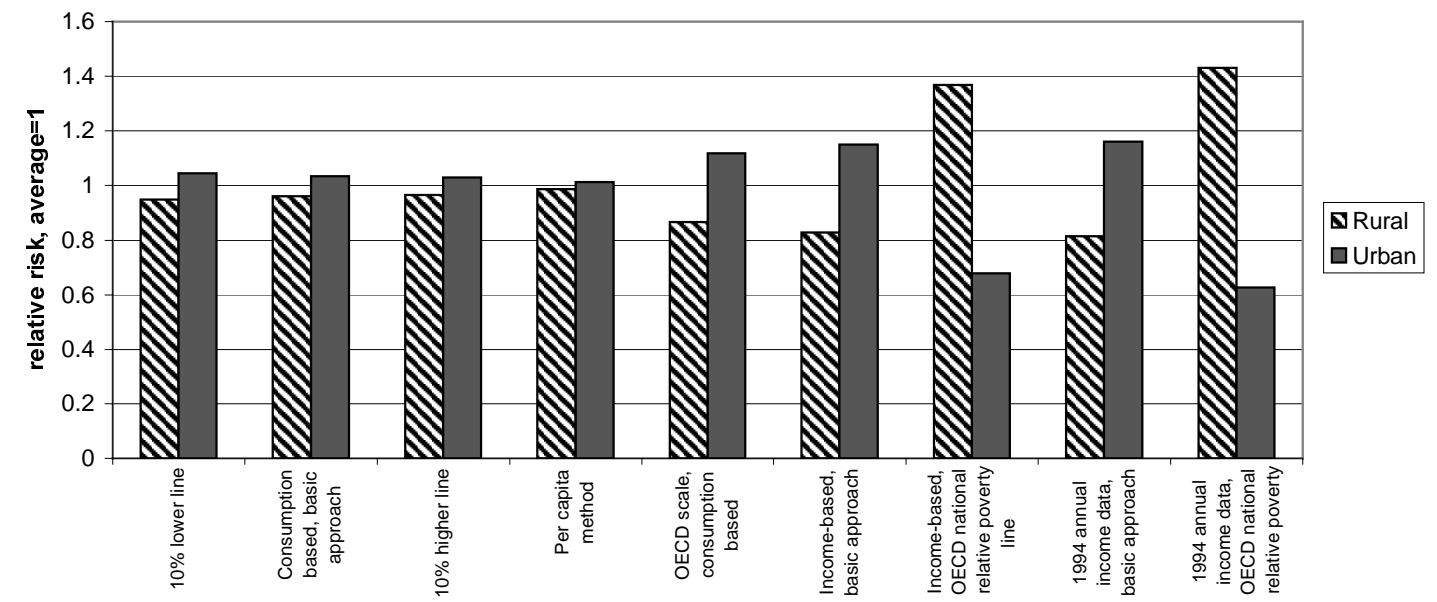

61. Relative risk of poverty by gender of household head is sensitive to the measurement assumptions as well.

Sensitivity of poverty risk by gender of $h / h$ head to methodology of poverty measurement

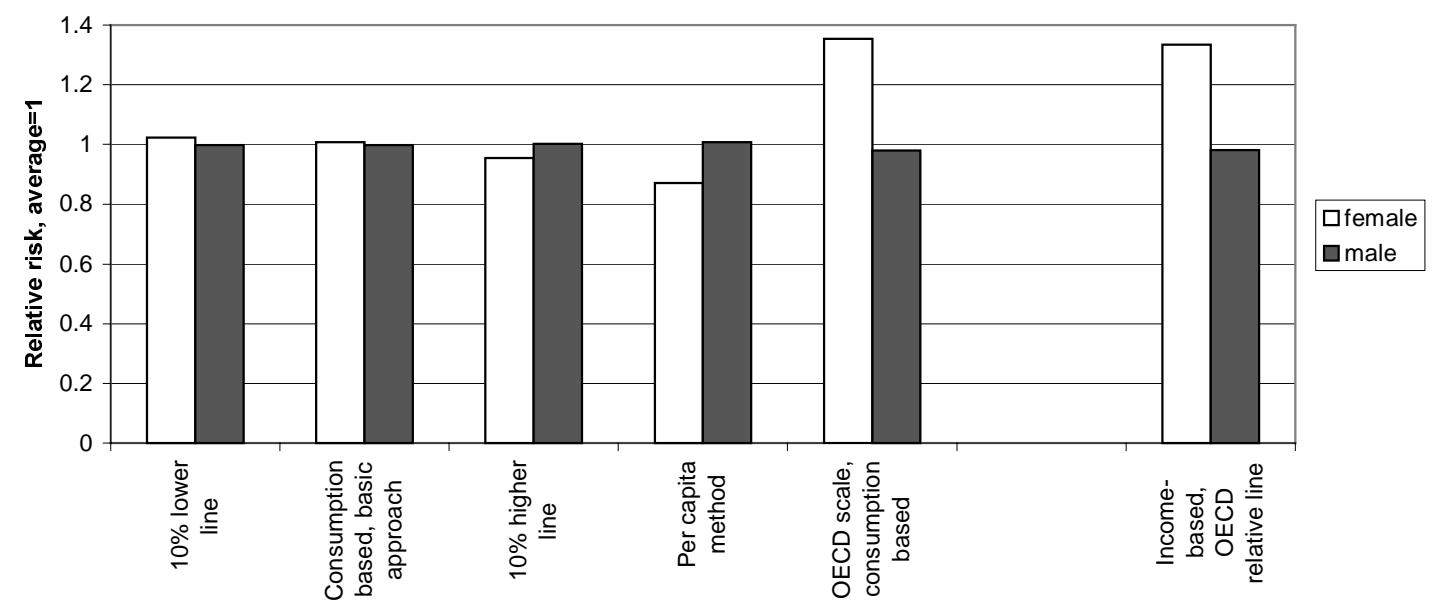


62. Relative risks of poverty by regions are reasonably robust to changes in the methodology, in a sense that poorest and richest regions do preserve their rank across methods. However, there is a substantial amount of re-ranking in the middle with different approaches.

Methodology of poverty measurement and poverty risks by regions

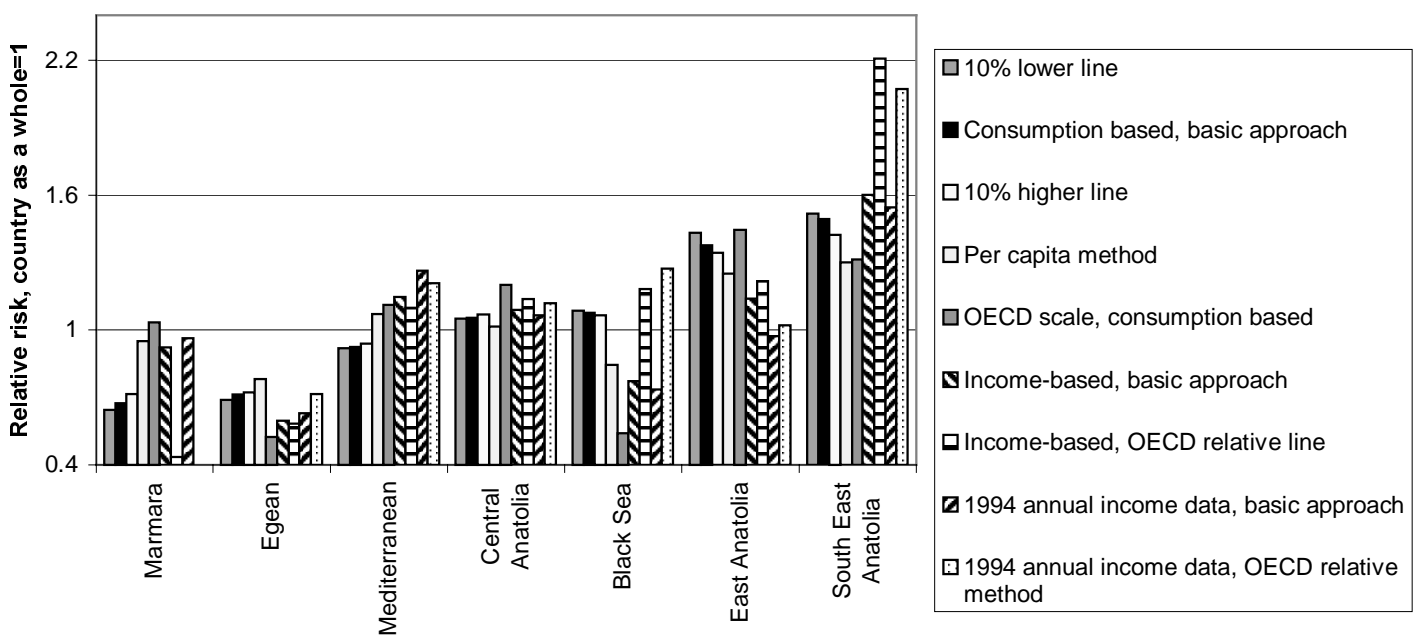

63. The type of education is key determinant of poverty risk regardless of what assumptions are used to measure poverty. This is the most robust and consistent finding that holds across all methodologies, datasets and approaches applied.

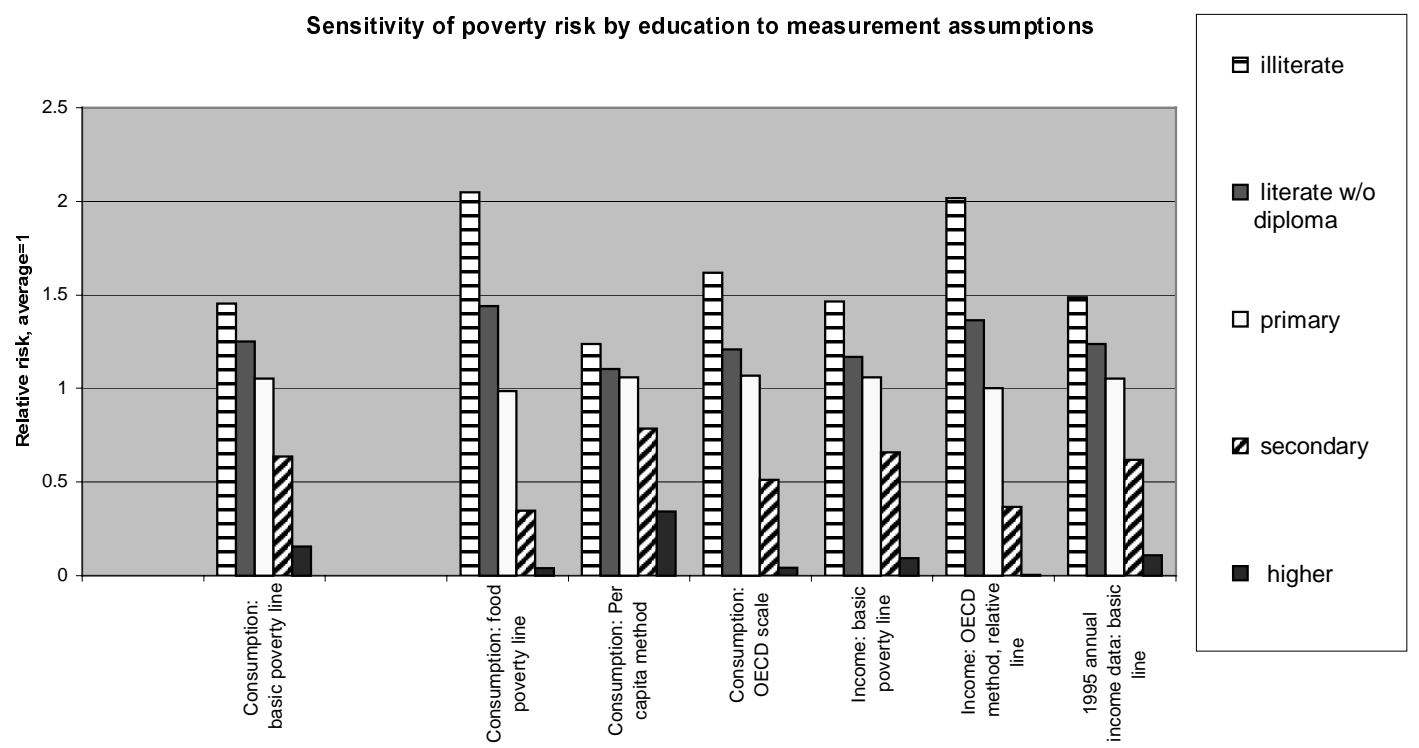

64. The poverty profile has identified that households headed by the self-employed constitute the largest group. However, the concern is, particularly for the self-employed, that the use of monthly data may overstate their poverty, since both income and consumption for this group tend to fluctuate over a year. When we look at the structure of poverty in the following graph, we do 
see indeed some important changes across methodologies and datasets. However, the main groups approximately hold their share in total poverty.

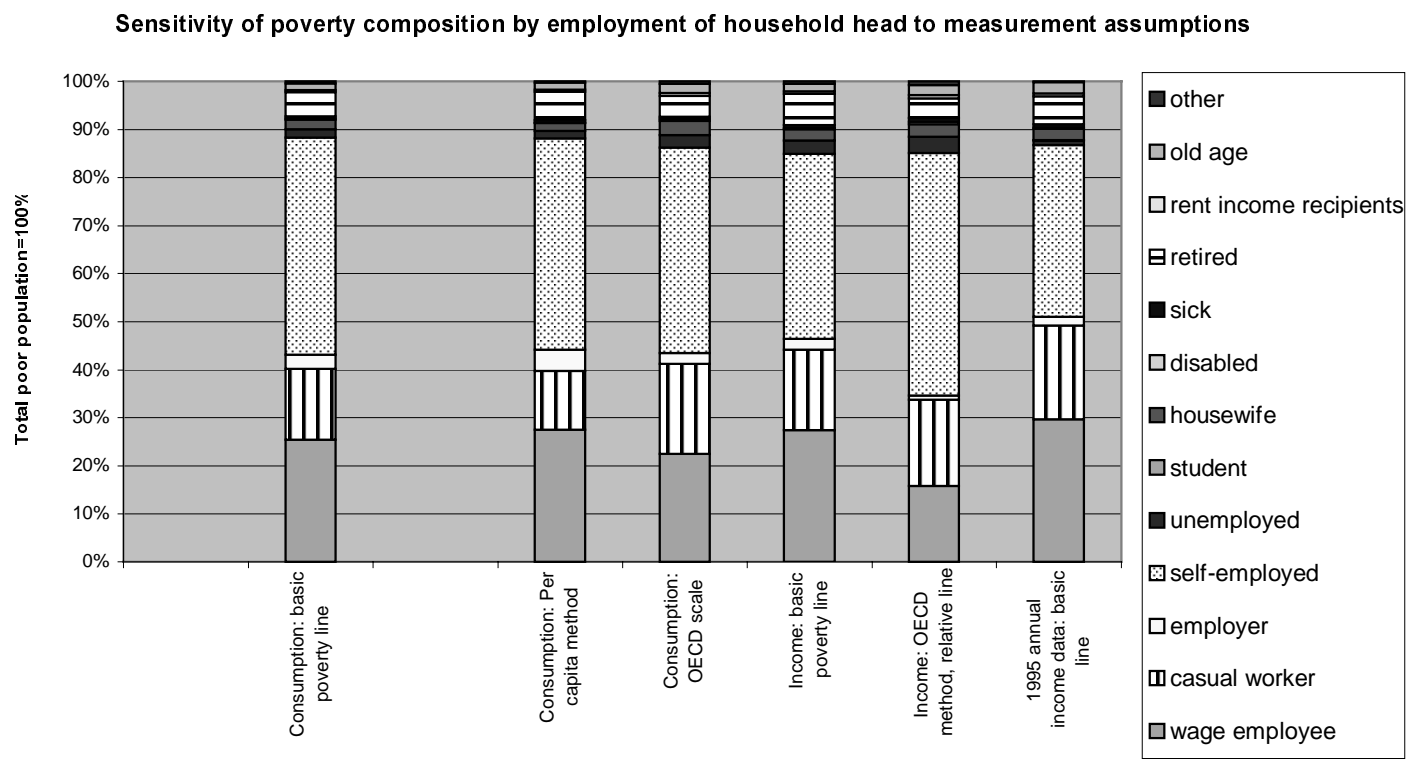

65. If we look at the graph that compares the relative risk of poverty by employment type across methodologies, we see quite a robust picture, where the casual employed and the unemployed have a much higher risk with any methodology. There is a remarkable stability and robustness of conclusions regarding the relative risk by employment status. The use of annual income data for 1994 does not change the picture of poverty by main groups.

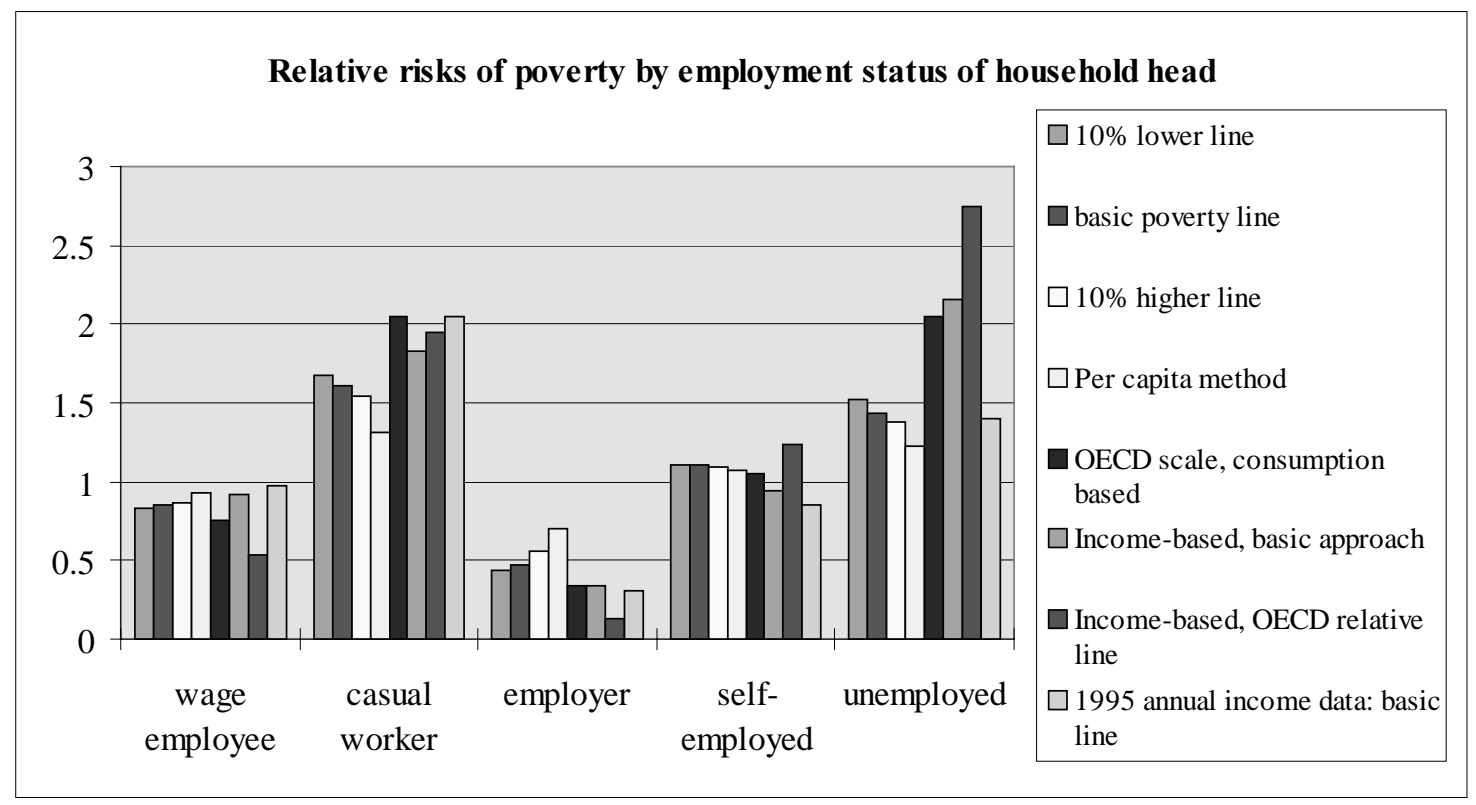

66. Therefore, the key determinants of poverty and economic vulnerability are the same across all methodologies and approaches surveyed. Demographic and location factors are less robust to changes in measurement assumptions. 


\section{Conclusion}

67. Poverty in Turkey is measured with reasonably good precision. The applied methodology uses most of the best practice approaches. It is based on using a comprehensive consumption measure as the welfare indicator, on adjusting for economies of scale in consumption and on using survey-generated prices to value the poverty basket. The minimum standard adopted in Turkey is relatively high for a developing economy that may lead to excessively high estimates of poverty risks. However, the profile of poverty, especially with respect to economic factors, is robust across all methodologies and datasets used. This suggests that causes of poverty and economic vulnerability can be subject to in-depth consistent analysis. 


\section{IZA Discussion Papers}

No Author(s)

161

V. Gimpelson

D. Treisman

G. Monusova

162

C. Dustmann

M. E. Rochina-

Barrachina

R. A. Hart

Y. Ma

164 M. A. Shields

S. Wheatley Price

165

A. Barrett

J. FitzGerald

B. Nolan

G. S. Epstein

A. L. Hillman

R. Winkelmann

T. K. Bauer

K. F. Zimmermann

C. Dustmann

F. Windmeijer

D. Card

D. S. Hamermesh

E. Fehr

J.-R. Tyran

M. Lofstrom

W. Meyer

Titel

Area

Date

Public Employment and Redistributive Politics:

4

$6 / 00$

Evidence from Russia's Regions

Selection Correction in Panel Data Models: An 6

Application to Labour Supply and Wages

Why do Firms Pay an Overtime Premium?

5

$6 / 00$

Racial Harassment, Job Satisfaction and Intentions

5

$6 / 00$

to Quit: Evidence from the British Nursing Profession

Immigration in a High Unemployment Economy: 1

$6 / 00$ The Recent Danish Experience

The Impact of Alcohol Consumption on Occupa- 5 tional Attainment in England

$6 / 00$

Earnings Inequality, Returns to Education and 5 Immigration into Ireland

$6 / 00$

Social Harmony at the Boundaries of the Welfare 3 State: Immigrants and Social Transfers

$6 / 00$

Immigration Policies and their Impact: The Case of 1

$7 / 00$

New Zealand and Australia

Immigration Policy in Integrated National

$7 / 00$

Economies

Wages and the Demand for Health - A Life Cycle 5

$7 / 00$

Analysis

Reforming the Financial Incentives of the Welfare 3

System

$7 / 00$

Timing, Togetherness and Time Windfalls

$7 / 00$

Does Money Illusion Matter? An Experimental

7

$7 / 00$

Approach

Self-Employment and Earnings among High-

Skilled Immigrants in the United States

Industrial Relations and the Wage Differentials

5

$7 / 00$ between Skilled and Unskilled Blue-Collar

Workers within Establishments: An Empirical

Analysis with Data of Manufacturing Firms 
177 B. R. Chiswick

G. Repetto

178 R. Euwals M. Ward

179 E. Wasmer

P. Weil

180 T. K. Bauer

I. N. Gang

181 E. Wasmer

Y. Zenou

182 M. Fertig

C. M. Schmidt

183 M. Fertig

C. M. Schmidt

184 M. Corak

B. Gustafsson

T. Österberg

185

H. Bonin

K. F. Zimmermann

186

C. Dustmann

T. K. Bauer

M. Lofstrom

K. F. Zimmermann

188 A. Kapteyn

A. S. Kalwij

A. Zaidi

189 W. Arulampalam

190

C. Dustmann

I. Preston

191

G. C. Giannelli

C. Monfardini

192

G. Brunello

A. Kunze
Immigrant Adjustment in Israel: Literacy and

Fluency in Hebrew and Earnings

The Renumeration of British Academics

The Macroeconomics of Labor and Credit Market Imperfections

Sibling Rivalry in Educational Attainment:

The German Case

Space, Search and Efficiency

2

Discretionary Measures of Active Labor Market

Policy: The German Employment Promotion Reform in Perspective

Aggregate-Level Migration Studies as a Tool for 1 Forecasting Future Migration Streams

Intergenerational Influences on the Receipt of

3

Unemployment Insurance in Canada and Sweden

The Post-Unification German Labor Market

4

$8 / 00$

Temporary Migration and Economic Assimilation

$8 / 00$

Immigration Policy, Assimilation of Immigrants and Natives' Sentiments towards Immigrants: Evidence from 12 OECD-Countries

The Myth of Worksharing

Is Unemployment Really Scarring? Effects of Unemployment Experiences on Wages

Racial and Economic Factors in Attitudes to Immigration

Joint Decisions on Household Membership and Human Capital Accumulation of Youths: The role of expected earnings and local markets

Absolute Risk Aversion and the Returns to Education

The Determination of Wages and the Gender Wage Gap: A Survey 
195 F. Büchel

A. Mertens

196 J. S. Earle

K. Z. Sabirianova

197

G. A. Pfann

198 M. Kreyenfeld

C. K. Spiess

G. G. Wagner

199 H. Entorf

200 T. Bauer

G. S. Epstein

I. N. Gang

201 T. J. Dohmen

G. A. Pfann

202

P. Francois

J. C. van Ours

203
J. M. Abowd
F. Kramarz
D. N. Margolis
T. Philippon

204

G. S. Epstein
A. L. Booth
M. Francesconi
J. Frank

206 C. M. Schmidt

R. Baltussen

R. Sauerborn

C. M. Schmidt

J. Hartog

R. Winkelmann

209 M. Barbie

M. Hagedorn

A. Kaul

210 T. J. Dohmen
Overeducation, Undereducation, and the Theory

of Career Mobility

Equilibrium Wage Arrears: A Theoretical and 4

Empirical Analysis of Institutional Lock-In

Options to Quit

1

$9 / 00$

A Forgotten Issue: Distributional Effects of Day 3

Care Subsidies in Germany

Rational Migration Policy Should Tolerate Non-

Zero Illegal Migration Flows: Lessons from

Modelling the Market for Illegal Migration

What are Migration Networks?

$9 / 00$

Worker Separations in a Nonstationary Corporate 1 Environment

Gender Wage Differentials in a Competitive Labor Market: The Household Interaction Effect

The Tail of Two Countries: Minimum Wages and 5 Employment in France and the United States

5

$9 / 00$

$9 / 00$

Labor Market Interactions Between Legal and

1

$10 / 00$ Illegal Immigrants

Temporary Jobs: Stepping Stones or Dead Ends? 1

$10 / 00$

The Evaluation of Community-Based Interventions: Group-Randomization, Limits and Alternatives

Arbeitsmarktpolitische Maßnahmen und ihre

6

$10 / 00$

Evaluierung: eine Bestandsaufnahme

Dutch Migrants in New Zealand:

Did they Fare Well?

1

$10 / 00$

Dynamic Effciency and Pareto Optimality in a

3

$10 / 00$ Stochastic OLG Model with Production and Social Security 

211 A. van Soest
M. Das
X. Gong
212 X. Gong
A. van Soest
P. Zhang
213 X. Gong
A. van Soest
E. Villagomez

214 X. Gong

A. van Soest

215 J. Ermisch

M. Francesconi

216 F. Büchel

217 J. Hansen

R. Wahlberg

218 C. Dustmann

A. van Soest

219 F. Kramarz

T. Philippon

220 W. A. Cornelius

E. A. Marcelli

221

C. Grund

222 W.P.M. Vijverberg

223 M. Rosholm

M. Svarer

224

J. Schwarze

225

L. Modesto

J. P. Thomas
A Structural Labour Supply Model with

The Effects of Overeducation on Productivity in Mexico

Wages as Risk Compensation in Germany 

former Soviet Union to Israel: Who is coming when? 

of Labor Income Risk and Car Insurance in the UK 1969-95 Soviet Union: A Study of the Suicide Epidemic in the 1990s

244 S. M. Fuess, Jr. M. Millea

245 F. Andersson K. A. Konrad

246 E. Plug W. Vijverberg

247 E. Plug W. Vijverberg

248 P. M. Picard E. Toulemonde

249 B. M. S. van Praag P. Cardoso

Pay and Productivity in a Corporatist Economy: Evidence from Austria

Globalization and Human Capital Formation

(

(1) 